\title{
Adverse effects of biologics: a network meta-analysis and Cochrane overview (Review)
}

Singh JA, Wells GA, Christensen R, Tanjong Ghogomu E, Maxwell LJ, MacDonald JK, Filippini G, Skoetz N, Francis DK, Lopes LC, Guyatt GH, Schmitt J, La Mantia L, Weberschock T, Roos JF, Siebert H, Hershan S, Cameron C, Lunn MPT, Tugwell P, Buchbinder R

Singh JA, Wells GA, Christensen R, Tanjong Ghogomu E, Maxwell LJ, MacDonald JK, Filippini G, Skoetz N, Francis DK, Lopes LC, Guyatt GH, Schmitt J, La Mantia L, Weberschock T, Roos JF, Siebert H, Hershan S, Cameron C, Lunn MPT, Tugwell P, Buchbinder R.

Adverse effects of biologics: a network meta-analysis and Cochrane overview. Cochrane Database of Systematic Reviews 2011, Issue 2. Art. No.: CD008794. DOI: 10.1002/14651858.CD008794.pub2.

www.cochranelibrary.com 
HEADER

ABSTRACT

PLAIN LANGUAGE SUMMARY

BACKGROUND

OBJECTIVES

METHODS

RESULTS

Figure 1.

Figure 2.

Figure 3.

Figure 4.

Figure 5.

Figure 6.

DISCUSSION

AUTHORS' CONCLUSIONS

ACKNOWLEDGEMENTS

REFERENCES

ADDITIONAL TABLES

APPENDICES

FEEDBACK

WHAT'S NEW

HISTORY

CONTRIBUTIONS OF AUTHORS

DECLARATIONS OF INTEREST

SOURCES OF SUPPORT

INDEX TERMS

\section{TABLE OF CONTENTS}

1

1

2

4

5

5 
[Overview of Reviews]

\section{Adverse effects of biologics: a network meta-analysis and Cochrane overview}

Jasvinder A Singh'1, George A Wells², Robin Christensen³ ${ }^{3}$, Elizabeth Tanjong Ghogomu4 ${ }^{4}$, Lara J Maxwell5 ${ }^{5}$, John K MacDonald6, Graziella Filippini ${ }^{7}$, Nicole Skoetz 8 , Damian K Francis ${ }^{9}$, Luciane C Lopes ${ }^{10}$, Gordon H Guyatt ${ }^{11}$, Jochen Schmitt ${ }^{12}$, Loredana La Mantia13, Tobias Weberschock ${ }^{14,15}$, Juliana F Roos ${ }^{16}$, Hendrik Siebert ${ }^{17}$, Sarah Hershan ${ }^{18}$, Chris Cameron2 ${ }^{2}$ Michael PT Lunn ${ }^{19}$, Peter Tugwell20,21,22, Rachelle Buchbinder23

1Department of Medicine, Birmingham VA Medical Center, Birmingham, AL, USA. 2Department of Epidemiology and Community Medicine, University of Ottawa, Ottawa, Canada. ${ }^{3}$ Musculoskeletal Statistics Unit, The Parker Institute, Copenhagen University Hospital, Bispebjerg og Frederiksberg, Copenhagen, Denmark. ${ }^{4}$ Bruyère Research Institute, University of Ottawa, Ottawa, Canada. ${ }^{5}$ Centre for Practice-Changing Research (CPCR), Ottawa Hospital Research Institute (OHRI), The Ottawa Hospital - General Campus, Ottawa, Canada. ${ }^{6}$ Cochrane IBD Group, Robarts Clinical Trials, London, Canada. ${ }^{7}$ Scientific Direction, Fondazione I.R.C.C.S. Istituto Neurologico Carlo Besta, Milano, Italy. ${ }^{8}$ Cochrane Haematological Malignancies Group, Department I of Internal Medicine, University Hospital of Cologne, Cologne, Germany. ${ }^{9}$ Epidemiology Research Unit, University of West Indies, Mona Kingston 7, Jamaica. ${ }^{10}$ Sciences of Pharmaceutical Program, University of Sorocaba, São Paulo, Sorocaba, Brazil. 11Department of Clinical Epidemiology and Biostatistics, McMaster University, Hamilton, Canada. ${ }^{12}$ Center for Evidence-Based Healthcare, Faculty of Medicine Carl Gustav Carus, Technischen Universität (TU) Dresden, Dresden, Germany. ${ }^{13}$ Unit of Neurorehabilitation - Multiple Sclerosis Center, I.R.C.C.S. Santa Maria Nascente - Fondazione Don Gnocchi, Milano, Italy. ${ }^{14}$ Evidence-Based Medicine Frankfurt, Institute of General Practice, Goethe University, Frankfurt, Germany. 15Department of Dermatology, Venereology, and Allergology, J.W. Goethe-University Hospital, Frankfurt, Germany. ${ }^{16}$ Dept of Clinical Pharmacy \& Pharmacy Practice, Dubai Pharmacy College, Dubai, United Arab Emirates. ${ }^{17}$ Cochrane Haematological Malignancies Group, University Hospital Cologne, Cologne, Germany. 18Monash Department of Clinical Epidemiology at Cabrini Hospital, Department of Epidemiology and Preventive Medicine, Monash University, Malvern, Australia. 19Department of Neurology and MRC Centre for Neuromuscular Diseases, National Hospital for Neurology and Neurosurgery, London, UK. 20Department of Medicine, Faculty of Medicine, University of Ottawa, Ottawa, Canada. ${ }^{21}$ Ottawa Hospital Research Institute, Clinical Epidemiology Program, Ottawa, Canada. 22Department of Epidemiology and Community Medicine, Faculty of Medicine, University of Ottawa, Ottawa, Canada. 23Monash Department of Clinical Epidemiology, Cabrini Hospital, Department of Epidemiology and Preventive Medicine, School of Public Health and Preventive Medicine, Monash University, Malvern, Australia

Contact address: Jasvinder A Singh, Department of Medicine, Birmingham VA Medical Center, Faculty Office Tower 805B, 510 20th Street South, Birmingham, AL, 35294, USA. jasvinder.md@gmail.com.

Editorial group: Cochrane Musculoskeletal Group.

Publication status and date: Edited (no change to conclusions), published in Issue 4, 2016.

Citation: Singh JA, Wells GA, Christensen R, Tanjong Ghogomu E, Maxwell LJ, MacDonald JK, Filippini G, Skoetz N, Francis DK, Lopes LC, Guyatt GH, Schmitt J, La Mantia L, Weberschock T, Roos JF, Siebert H, Hershan S, Cameron C, Lunn MPT, Tugwell P, Buchbinder R. Adverse effects of biologics: a network meta-analysis and Cochrane overview. Cochrane Database of Systematic Reviews 2011 , Issue 2. Art. No.: CD008794. DOI: 10.1002/14651858.CD008794.pub2.

Copyright $@ 2016$ The Cochrane Collaboration. Published by John Wiley \& Sons, Ltd.

\section{A B S T R A C T}

\section{Background}

Biologics are used for the treatment of rheumatoid arthritis and many other conditions. While the efficacy of biologics has been established, there is uncertainty regarding the adverse effects of this treatment. Since important risks such as lymphomas, serious infections and tuberculosis (TB) reactivation may be more common to the biologics but occur in small numbers across the various indications, we planned to combine the results from biologics used in many conditions to obtain much needed risk estimates. 


\section{Objectives}

To compare the potential adverse effects of tumor necrosis factor inhibitor (adalimumab, certolizumab, etanercept, golimumab, infliximab), interleukin (IL)-1 antagonist (anakinra), IL-6 antagonist (tocilizumab), anti-CD28 (abatacept), and anti-B cell (rituximab) therapy in patients with any disease condition except human immunodeficiency disease (HIV/AIDS).

\section{Methods}

Randomized controlled trials (RCTs), controlled clinical trials (CCTs) and open-label extension (OLE) studies that studied one of the nine biologics for use in any indication (with the exception of HIV/AIDS) and that reported our pre-specified adverse outcomes (serious adverse events (SAEs), withdrawals due to adverse events (AEs), total AEs, serious infections; specific AEs, namely, tuberculosis (TB) reactivation, lymphoma and congestive heart failure) were considered for inclusion. We searched The Cochrane Library, MEDLINE, and EMBASE (to January 2010). Identifying search results and data extraction were performed independently and in duplicate. For the network metaanalysis, we performed both Bayesian mixed-treatment comparison models and arm-based generalized linear mixed models.

\section{Main results}

We included 160 RCTs with 48,676 participants and 46 extension studies with 11,954 participants. The median duration of RCTs was six months and 13 months for OLEs. Data were limited for TB reactivation, lymphoma, and congestive heart failure. Using standard dose, compared with control, biologics as a group were associated with a statistically significant higher rate of total AEs (odds ratio (OR) 1.28, 95\% credible interval $(\mathrm{Cl}) 1.09$ to 1.50; number needed to treat to harm (NNTH) $=22,95 \%$ confidence interval $(\mathrm{Cl}) 14$ to 60$)$, withdrawals due to $\mathrm{AEs}(\mathrm{OR} 1.47,95 \% \mathrm{Cl} 1.20$ to 1.86 ; NNTH $=26,95 \% \mathrm{Cl} 15$ to 58 ), serious infections (OR, $1.37,95 \% \mathrm{Cl} 1.04$ to $1.82, \mathrm{NNTH}=10895 \% \mathrm{Cl}$, 50 to 989 ) and TB reactivation (OR 4.68, $95 \% \mathrm{Cl} 1.18$ to 18.60 ; NNTH $=681,95 \% \mathrm{Cl} 143$ to 14706 ).

The rate of SAEs, lymphoma and congestive heart failure were not statistically significantly different between biologics and control treatment.

Certolizumab pegol (OR 4.75, 95\% $\mathrm{Cl} 1.52$ to 18.65 ; NNTH = 12, 95\% Cl 4 to 79 ) and anakinra (OR 4.05, 95\% $\mathrm{Cl} 1.22$ to 16.84 ; NNTH = $14,95 \%$ $\mathrm{Cl} 4$ to 181) were associated with a statistically significantly higher risk of serious infections compared with control treatment. Compared with control, certolizumab was associated with a statistically significantly higher risk of SAEs (as defined in included studies: OR 1.57, 95\% $\mathrm{Cl} 1.06$ to $2.32 ; \mathrm{NNTH}=18,95 \% \mathrm{CI} 9$ to 162 ). Infliximab was associated with a statistically significantly higher risk of total AEs OR $1.55,95 \%$ $\mathrm{Cl} 1.01$ to 2.35 ; $\mathrm{NNTH}=13,95 \% \mathrm{Cl} 8$ to 505$)$ and withdrawals due to AEs compared with control (OR $2.34,95 \% \mathrm{Cl} 1.40$ to $4.14 ; \mathrm{NNTH}=10$, $95 \% \mathrm{Cl} 5$ to 30$)$.

The overall numbers were relatively small for indirect comparisons. Indirect comparisons revealed that certolizumab pegol was associated with a statistically significantly higher odds of serious infections compared with abatacept, adalimumab, etanercept, golimumab and rituximab; and anakinra was statistically significantly more likely than rituximab to be associated with serious infections. Certolizumab pegol was associated with a statistically significant higher odds of SAEs compared with adalimumab and abatacept. No statistically significant differences were noted between biologics in total AEs or withdrawals due to AEs in indirect comparisons.

\section{Authors' conclusions}

Overall, in the short term biologics were associated with statistically significantly higher rates of serious infections, TB reactivation, total AEs and withdrawals due to AEs. Serious infections included opportunistic infections as well as bacterial infections in most studies. Some biologics had a statistically higher association with certain adverse outcomes compared with control, but there was no consistency across the outcomes so caution is needed in interpreting these results.

There is a need for more research regarding the long-term safety of biologics and an urgent need for comparative safety reports of different biologics; preferably without industry involvement. National and international registries and other types of large databases are relevant sources for providing complementary evidence regarding the short- and longer-term safety of biologics.

\section{PLAIN LANGUAGE SUMMARY}

\section{Side effects of nine commonly used biologics}

This summary of a Cochrane review presents what we know from research about the side effects of biologics used for many conditions including inflammatory arthritis and other inflammatory conditions, cancer, and neurological conditions. We did not include studies on HIV/AIDS. The nine biologics we studied were: abatacept (Orencia ${ }^{\circledR}$ ), adalimumab (Humira ${ }^{\circledR}$ ), anakinra (Kineret $^{\oplus}$ ), certolizumab pegol (Cimzia ${ }^{\circledR}$ ), etanercept (Enbrel ${ }^{\circledR}$ ), golimumab (Simponi ${ }^{\circledR}$ ), infliximab (Remicade ${ }^{\circledR}$ ), rituximab (Rituxan or Mabthera ${ }^{\circledR}$ ) and tocilizumab (Actmera ${ }^{\circledR}$ ).

\section{The review shows that people using these biologics in the short term:}

- will probably be a little more likely to experience more serious infections or tuberculosis than people who take placebo (fake drug); - will probably be a little more likely to experience side effects or drop out of the study due to side effects than people who take placebo; 
- will probably not experience more serious side effects* (other than serious infections), cancer, or congestive heart failure than people who take placebo.

( ${ }^{\star} \mathrm{A}$ serious side effect is a life threatening adverse event that can result in death or hospitalization and disability or permanent damage).

We do not have precise information about other possible side effects and complications, including rare or long-term side effects.

What are biologics?

Biologics are a group of medications that suppress the immune system and reduce the inflammation, even though suppressing the immune system can make it slightly harder to fight off infections.

\section{Best estimate of what happens to people who take biologics in the short term (range: 1 to 63 months)}

\section{Serious side effects}

Among people who took any biologic, 127 out of 1,000 had serious side effects compared with 118 people out of 1,000 who took placebo (1\% absolute harm).

\section{All side effects reported}

Among people who took any biologic, 770 out of 1,000 had side effects compared with 724 people out of 1,000 who took placebo (5\% absolute harm).

\section{Drop-out of study due to side effects}

Among people who took any biologic, 137 out of 1,000 dropped out of the study due to side effects compared with 98 people out of 1,000 who took placebo ( $4 \%$ absolute harm).

\section{Serious infections}

Among people who took any biologic, 35 people out of 1000 experienced serious infections compared with 26 people out of 1000 who took placebo ( $1 \%$ absolute harm).

\section{Tuberculosis}

Among people who took any biologic, 20 out of 10,000 had tuberculosis compared with 4 people out of 10,000 who took placebo (0.16\% absolute harm). However, there were not many cases of tuberculosis so our confidence in this result is low.

\section{Lymphoma (Cancer of the blood)}

Over the short time frame of these trials, there may be little or no difference in the number of people who experienced cancer while taking any biologic compared with people who took placebo. However, there were not many cases of cancer so our confidence in this result is low.

\section{Congestive heart failure}

There may be little or no difference in the number of people who experienced heart failure taking any biologic compared with people who took placebo. However, there were not many cases of congestive heart failure so our confidence in this result is low. 


\section{B A C K G R O U N D}

\section{Description of the condition}

Many biologic agents have been introduced to treat rheumatoid arthritis (RA) in the last two decades. RA is an inflammatory arthritis characterized by joint and systemic inflammation; joint pain, deformity and destruction (Harris 1990). RA affects 0.5\% to $1.0 \%$ of the adult population worldwide (Kvien 2004) and is associated with significant work disability, functional limitation, and deficits in health-related quality of life (HRQoL) (Kvien 2005; Lubeck 2004; Odegard 2005; Pincus 1983; Yelin 2007).

Many biologics initially introduced for treatment of RA have also been used for several other conditions, such as psoriasis (Rozenblit 2009), psoriatic arthritis (Golicki 2009), ankylosing spondylitis (Zochling J) and inflammatory bowel disease (IBD) (Behm 2008). Additionally, some biologics such as rituximab were initially used for treatment of lymphoproliferative disorders (Schulz 2007; Vidal 2009) before being used for the treatment of RA. Biologics have also been used in the treatment of neurological disorders (Menge 2008). Thus, biologics commonly used for treatment of RA are also being used for treatment of several other diseases.

\section{Description of the interventions}

The main objective of this review was to review the safety of the nine biologics available for treatment of RA by including all data for these nine biologics in RA and other conditions. We included the following nine biologics.

1. Five tumor necrosis factor (TNF) inhibitors (Scott 2006): infliximab (Remicade ${ }^{\circledR}$ ), approved for RA in the US in 1998 (FDA 1999; FDA 2009e); etanercept $\left(\right.$ Enbrel $\left.^{\circledR}\right)$, approved for RA in 1998 (FDA 1998a; FDA 1998b); adalimumab (Humira ${ }^{\circledR}$ ), approved for RA in 2002 (FDA 2002a; FDA 2002b); certolizumab pegol (Cimzia ${ }^{\circledR}$ ), approved for RA in 2008 (FDA 2009c); and golimumab (Simponi ${ }^{\circledR}$ ), approved for RA in 2009 (FDA 2009a; FDA 2009b).

2. Anti-interleukin (IL)1 therapy: anakinra (Kineret ${ }^{\circledR}$ ), approved for RA in 2001 (FDA 2001).

3. Anti-CTLA4 therapy: abatacept (Orencia ${ }^{\circledR}$ ), approved for RA in 2005 (FDA 2005; FDA 2009d).

4. Anti-CD20 therapy: rituximab (Rituxan ${ }^{\oplus}$ or Mabthera ${ }^{\circledR}$, approved for lymphoma in 1997 and for RA in 2006 (Drugs.com 2006; FDA 2006).

5. Anti-IL6 therapy: tocilizumab (Actmera ${ }^{\circledR}$ ), approved for RA in 2010 (FDA 2010).

Medications are administered subcutaneously except for infliximab, abatacept, rituximab, and tocilizumab which are administered as intravenous infusions.

\section{How the intervention might work}

These biologics target various immune cells or cytokines that play a key role in local and systemic inflammation. Several biologics target tumor necrosis factor (TNF)-alpha in the joint lining, bone, and other tissues; while others target T-cells, B-cells and interleukins (IL). Anti-TNF biologics include both soluble receptors that serve as decoy receptors competing with TNF-receptors (etanercept) and monoclonal antibodies targeting the TNF-receptors (infliximab, adalimumab, golimumab, and certolizumab pegol). Anakinra is an
IL-1 receptor antagonist, targeting another cytokine important in RA pathogenesis. Rituximab is a monoclonal antibody against CD20, which is found primarily on B-cells. Abatacept is a man-made fusion protein, inhibiting co-stimulation of T-cells. Due to the different mechanisms of action for these biologics, several adverse events (SAEs) such as tuberculosis (TB) reactivation with TNF-inhibitors and neutropenia and lipid abnormalities with tocilizumab are drug specific. However, some adverse events (AEs) such as increased risk of infection are related to a general immunomodulator or immunosuppressive effect and are common to all biologics.

\section{Why it is important to do this overview}

Placebo-controlled trials have demonstrated that biologics are effective in decreasing joint and systemic inflammation, delaying radiographic joint destruction, preventing disability, and improving productivity in patients with RA and other types of inflammatory arthritis (Blumenauer 2002; Blumenauer 2003; Doherty 2009; Keystone 2009b; Maxwell 2009; Mertens 2009; Navarro-Sarabia 2005; Ruiz Garcia 2011; Singh 2009a; Singh 2009b; Singh 2010a; Singh 2010b; Strand 2008; Strand 2010). Safety is an important issue and with a limited number of RCTs included in each condition it is prudent to pool safety data across conditions to provide a better understanding of toxicity. This uses an approach recommended by The Cochrane Collaboration (Becker 2008) and will assist clinicians and patients in making more informed treatment choices. As evidence accumulates, even rare adverse events (AEs) with a medication may become apparent. An example of the strength of cumulative evidence is the recent recognition of the risk of infections including TB with anti-TNF biologics by the US Food and Drug Administration (FDA) as larger numbers of patients are exposed to treatment over time. We believe that most AEs from medications are independent of the underlying diagnoses for which the medication is being used, therefore, pooling the safety data from studies of biologics from different conditions is worthwhile.

Several of the AEs of interest are thought to be definitely linked to exposure to biologics. These include infusion reactions, an increased risk of infections including fungal injections, and TB reactivation. For several of these $A E s$, a biological rationale exists. For example, TNF is important in the immune response against infections, suggesting that medications that inhibit TNF may increase the risk of infections and reactivation of TB. The linkage to other AEs such as congestive heart failure and cancers is not as strong.

A systematic assessment of the safety of these nine biologics that are used for the treatment of RA has not been done. This network meta-analysis systematically assessed the adverse effects of the nine biologics using evidence from controlled trials of the treatment of any indicated condition (rheumatological and nonrheumatological), with the exception of human immunodeficiency disease (HIV/AIDS), for which these biologics are used. We recognize that since some of the AEs of interest are rare but serious, and occur during long-term use of biologics, we need to also look at nonrandomized studies to fully address our question. We plan to do a systematic review of non-randomized studies as a second phase to this project. 


\section{O B JECTIVES}

The primary objective was to assess the potential adverse effects of the nine biologics abatacept, adalimumab, anakinra, certolizumab pegol, etanercept, golimumab, infliximab, rituximab, and tocilizumab across different indications of use except human immunodeficiency disease (HIV/AIDS).

\section{METHODS}

\section{Criteria for considering reviews for inclusion}

Randomized controlled trials (RCTs), controlled clinical trials (CCTs) and open-label extension studies (OLEs) that studied one of the nine biologics for use in any indication (with the exception of HIV/ AIDS) and that reported any adverse outcome were considered for inclusion. These nine biologics were chosen since they are approved for the treatment of RA and other conditions in Europe, UK, USA, Canada, and Australia. All Cochrane and non-Cochrane systematic reviews were screened to identify additional RCTs, CCTs, and OLEs.

\section{Search methods for identification of reviews}

We searched the Cochrane Database of Systematic Reviews (The Cochrane Library), Health Technology Assessment Database (HTA), and Database of Abstracts of Reviews of Effects (DARE) to identify existing systematic reviews (see Appendix 1). We scanned the lists of studies included in these systematic reviews to assemble a list of known RCTs. Taking the date of the oldest of the systematic reviews we then ran searches in CENTRAL (The Cochrane Library), MEDLINE, and EMBASE to find RCTs, CCTs and OLEs which have been published since then, using the search strategies described in Appendix 2. We also ran a search with a filter for finding adverse effects as described in Appendix 3.

\section{Types of studies}

We considered RCTs, CCTs, and OLEs for inclusion.

\section{Types of participants}

Adults (aged 16 years or older) with any disease (except HIV/AIDS) included in studies of any of the nine biologics were considered for inclusion. As we were interested in adverse events that may occur rarely, we did not exclude studies based on disease. The only disease that we excluded from our review was HIV/AIDS due to the complexity of treating this condition.

\section{Types of interventions}

Interventions included abatacept, adalimumab, anakinra, certolizumab pegol, etanercept, golimumab, infliximab, rituximab, and tocilizumab alone or in combination with other therapies for any medical condition (other than HIV/AIDS) compared to any other therapy or placebo.

\section{Types of outcome measures}

\section{Major outcomes}

1. Number of serious adverse events (SAEs): counted as the total number of SAEs, as listed in each study. Most studies use good clinical practices and standard definitions, even when not explicitly specified. One of the common definitions used in studies is the U.S. Food and Drug Administration's
(FDA) definition for SAE, that includes death, life-threatening event, initial or prolonged hospitalization, disability, congenital anomaly or an adverse event requiring intervention to prevent permanent impairment or damage (FDA 2010b). If the total number of SAEs was not presented, we took the number of patients with any ( $\geq$ one) SAEs in a study (as defined in the study) for this outcome.

2. Withdrawals due to adverse events (AEs): defined in a standard manner in studies.

3. Number of AEs: defined as the total number of AEs. If the total number of AEs was not presented, we took the number of patients with any ( $\geqq$ one) AEs in a study (as defined in the study) for this outcome.

4. Number of serious infections: defined as 'serious infections' in each study (definitions varied but usually included infections associated with death, hospitalization, and use of intravenous antibiotics).

5. Tuberculosis (TB): diagnosis of $T B, T B$ reactivation, miliary or cavitary TB of the lung or any other body organ. If TB for the different organ systems was provided separately, we took the total of all cases in all organ systems. One patient could only contribute one case of TB, even if they had more than one organ with TB. Some studies presented the number of TB diagnoses; we assumed that this was the number of unique patients with TB.

6. Leukemia or lymphoma: a new diagnosis of leukemia or lymphoma.

7. Congestive heart failure (CHF): any diagnosis of $\mathrm{CHF}$ or $\mathrm{CHF}$ exacerbation

\section{Minor outcomes}

1. All cardiac AEs: these included the presence of any of the diagnoses CHF or CHF exacerbation, a new diagnosis of coronary heart disease (CAD) or angina, acute CAD event characterized by myocardial infarction or unstable angina, arrhythmia, malignant hypertension.

2. Infusion and injection site reactions: for intravenous medications, the number of infusion reactions and for subcutaneous medications, injection site reactions were included.

3. Allergic reactions: included skin rash or allergic reactions. If a study provided both anaphylactic and allergic reactions separately, we planned to add them to obtain the value for all allergic reactions.

4. Neurologic: these included a new diagnosis of one or more of multiple sclerosis, Guillain-Barre syndrome (GBS), chronic immune demyelinating polyneuropathy (CIDP), multifocal motor neuropathy, progressive multifocal leukoencephalopathy (PML), or other demyelinating neurologic disease. If a study presented both specific and grouped neurologic AEs, we planned to include the grouped data.

5. Death.

6. All cancers: all cancers including leukemia or lymphoma were extracted. If a study provided the total number of cancers and the number of lymphoproliferative cancers, we planned to include the total number of cancers. If a study only provided type- or site-specific cancers, we planned to calculate the total number of cancers. Where possible, we planned to extract the 
number of patients with cancers rather than the number of cancers (one patient may have more than one cancer).

7. Serious lung infection or pneumonia: serious lung infections as defined in each study were extracted. These are usually defined as lung infection with use of intravenous antibiotics, hospitalization, intubation, or death and could include pneumonia, lung abscess, and pyothorax. If not provided, we planned to calculate the total number of serious lung infections. If a study provided numbers for pneumonia and serious lung infections separately, then the number of cases of pneumonia were planned for inclusion.

8. Fungal infections: all fungal infections including but not limited to histoplasmosis, cryptococcosis, candidiasis, aspergillosis, mucormycosis, blastomycosis, and coccidioidomycosis. We planned to extract the total number of fungal infections if specified, or calculated the total number from the data provided.

9. Opportunistic infections: opportunistic infections as labeled in each study was extracted. If no opportunistic infections were reported, the value would be set to missing, since these were not being routinely reported specifically in initial trials of biologics.

As outlined above, for any adverse outcome in either the major or minor categories, if the number of cases of specific AEs and the overall number of AEs within a specific category were provided within a study, we extracted the overall number of AEs within the specific category except for the outcome of pneumonia and serious lung infection, where numbers for pneumonia rather than serious lung infection were extracted.

All outcomes were expressed as a percentage of the patients randomized (intention-to-treat analysis). For open-label extension studies, the number of patients entering the open-label phase was used as the denominator.

For each study, the duration of observation was extracted to calculate the person-years of exposure.

\section{Data collection and analysis}

\section{Selection of reviews}

Two teams of review authors (DF and JKM; EG and GF) independently assessed titles and abstracts to identify relevant studies for inclusion. The full text of the study was obtained when necessary to confirm inclusion. We included all completed RCTs, CCTs, or OLEs if the studies contained clinically relevant safety outcomes for any of the nine biologics and met the inclusion criteria listed above. We also screened the reference lists of systematic reviews to identify any studies missed by the electronic database search.

\section{Data extraction and management}

The data were extracted independently and in duplicate by the 10 review authors and an extraction partner. There was an overlap of two articles across all 10 review author teams to assess the interrater reliability of data extraction across the different teams (JS, ETG, NS, JKM, GF, LL, ML, LM, JS, RB). We performed data extraction using an Excel sheet that was piloted on 10 articles. Disagreements on extractions were resolved by discussion.

\section{Assessment of methodological quality of included reviews}

To assess the risk of bias of each included study, we used The Cochrane Collaboration recommendations for assessment. The criteria applied to measure the risk of bias included: allocation concealment, random sequence generation, presence of blinding in the studies (patients, assessors and physicians), incomplete outcome data, selective outcome reporting, and evidence of major baseline imbalance (Higgins 2011). In addition, the following criteria, specific to the assessment of adverse effects, were assessed.

- Adverse event definition: did the study provide a definition for 'serious adverse events'?

- Method of adverse event assessment: did the researchers actively monitor for AEs (low risk of bias) or did they simply provide spontaneous reporting of AEs that arose (high risk of bias)?

- The risk of bias of each study was explicitly judged on each criterion using the following: low risk of bias, high risk of bias, or unclear risk (either lack of information or uncertainty over the potential for bias).

\section{Data synthesis}

\section{Statistical analysis}

\section{Methods for the Bayesian mixed treatment comparison}

Following assessment of heterogeneity across trials in terms of patient characteristics, trial methodologies, and treatment protocols, we conducted Bayesian network meta-analyses for outcomes pre-specified in the PICO (Participants, Interventions, Comparisons, Outcomes) statement: withdrawal due to adverse event (WdAE), serious infection (SInf), serious adverse events (SAEs) and adverse events (AEs). The effect estimate chosen depends on the outcome of interest and the availability of data. WdAE is a simple binary variable, and SInf and SAE are essentially a simple binary event since the occurrence of multiple events of this nature is unlikely; for these outcomes the effect estimate chosen is the odds ratio (OR). For the outcome AE, multiple events are likely in which case the rate of the occurrence of the event is of interest. In the dose-adjusted analysis, we considered the following standard FDA doses as approved for use in RA patients (column two in Table 1) for calculating dose multiples for each biologic (last column in Table 1). Three general models were considered for including dose, namely: the standard dose model in which only the arms of the trials in which the standard dose equivalent was compared to control are included; considered; the unadjusted dose model in which all dose arms of the trials are included; and the dose-adjusted model in which all dose arms of the trials are included as a covariate in the model. The primary analysis was based on the standard dose model; sensitivity analyses were performed using unadjusted and dose-adjusted models. We conducted both fixed- and random-effects models; model selection was based on the deviance information criterion (DIC) and residual deviance. $\mathrm{R}$ (R Foundation for Statistical Computing, Vienna, Austria) and WinBUGS (MRC Biostatistics Unit, Cambridge, UK) were used for Bayesian network metaanalyses according to the routine which accommodates evidence structures which may consist of multi-arm trials as developed at the Universities of Bristol and Leicester. Posterior densities for unknown parameters were estimated using Markov Chain Monte Carlo methods. Basic parameters were assigned non-informative or 
vague prior distributions; more informative priors were considered after evaluation of the information base and clinical expert advice. Point estimates and 95\% credible intervals (conceptually similar to confidence intervals used in the frequentist approach) were used to summarize findings. Consistency between direct and indirect evidence were formally assessed using back-calculation and node splitting techniques. Model diagnostics included trace plots and the Brooks-Gelman-Rubin statistic (Ntzoufras 2008; Spiegelhalter 2003) to assess and ensure model convergence. Two chains were fitted in WinBUGS for each analysis, each usually employing $\geq 20,000$ iterations, with a burn-in of $\geq 20,000$ iterations.

\section{Methods for the frequentist general linear mixed model}

We also conducted generalized linear mixed models (GLMM) as part of the network meta-analysis for outcomes pre-specified in the PICO statement. We analyzed the outcome that follows a binomial distribution using a mixed log-binomial model with the logit link function to generate the OR estimates. We analyzed the outcome that follows a Poisson distribution using a mixed Poisson regression model. Again, three general models were considered when including dose. We conducted the random-effects GLMM model. We considered two random-effects in the model. The random-effects trial accounts for the response variables of patients within a given trial being correlated. The random-effects trial ${ }^{*}$ treatment accounts for the correlation of responses between any two patients from the same treatment arm within a given study. However, the inclusion of the random-effects trial ${ }^{\star}$ treatment depends on the composition of the data. In cases where the number of observations was lower than the number of model parameters to be estimated, then the model cannot sustain the inclusion of the trial ${ }^{*}$ treatment random-effects, and it is therefore, excluded from the model. The GLIMMIX procedure in SAS/STAT (SAS Institute Inc., Cary, NC, USA) was used for generalized linear mixed model network meta-analyses. We used point estimates and $95 \%$ confidence intervals to summarize findings. We evaluated model diagnostics evaluated using the diagnostic plots (e.g. residual plots) to assess and ensure model convergence.

We evaluated heterogeneity for the indirect comparison analyses using tau-squared, which examines heterogeneity because of study and study* drug interaction (smaller values indicate a better model). There is no specific range for this measure.

\section{Value of Information Analyses}

We performed value of information analyses to evaluate the precision of the estimate and whether the data on which our analyses were based had enough information for us to draw conclusions. This was based on an adaptation of classical monitoring boundaries for use in cumulative meta-analysis as guidelines for deciding when accumulating evidence is statistically significant and clinically relevant (Guyatt 2011). To inform this decision, we calculated the number of patients required for an adequately powered individual trial (termed the "optimal information size" [OIS]) (Pogue 1997).

\section{Subgroup analyses, planned comparisons}

The main analyses were of nine biologics compared with placebo and with each other.

The planned subgroup analyses were the following, if data were available:

1. TNF inhibitors versus nonTNF-inhibitors.

2. Medications targeting TNF receptor (etanercept) versus monoclonal antibodies against TNF (adalimumab, certolizumab pegol, golimumab, infliximab) versus other (tocilizumab, rituximab, abatacept).

3. Duration of randomized blinded study: < six months, six to 12 months, > 12 months.

4. Concomitant methotrexate or other disease modifying antirheumatic drug (DMARD) use versus no concomitant therapy versus 'other' therapy. The 'other' types of concomitant medication included DMARDs, steroids or non-steroidal antiinflammatory drugs (NSAIDs), and chemotherapy.

5. Analysis by drug dose (different doses have been approved for different conditions).

6. Ethnicity.

7. Gender.

8. Age $\leq 65$ years versus $>65$ years.

In response to peer reviewer comments, we undertook a post hoc analysis stratifying by disease condition (ankylosing spondylitis, cancer, IBD, psoriatic arthritis, psoriasis, RA, and other) to assess our underlying assumption that it is appropriate to pool results across all disease conditions.

\section{Presentation of key results}

The main results of the review are presented in the 'Summary of findings' (SoF) tables, as recommended by The Cochrane Collaboration (Schünemann 2008a). The SoF table includes an overall grading of the evidence related to each of the main outcomes, using the GRADE approach (Schünemann 2008b). The control event rates used in the calculation of absolute risks were: 118 per 1000 for SAEs; 724 per 1000 for total AEs; 98 per 1000 for withdrawals due to AEs; 26 per 1000 for serious infections; four per 10,000 for tuberculosis reactivation; nine per 10,000 for lymphoma; and eight per 1000 for congestive heart failure. These control event rates were calculated based on the number of events in the included studies.

This amendment focuses on the analyses related to major outcomes, SAEs, AEs, withdrawals due to AEs and serious infections. We did not amend the analyses for congestive heart failure, lymphoma, and TB reactivation, which will be done in the future.

\section{RE S U L T S}

A flow diagram describes the results of the electronic search (Figure 1). 
Figure 1. Flow diagram.

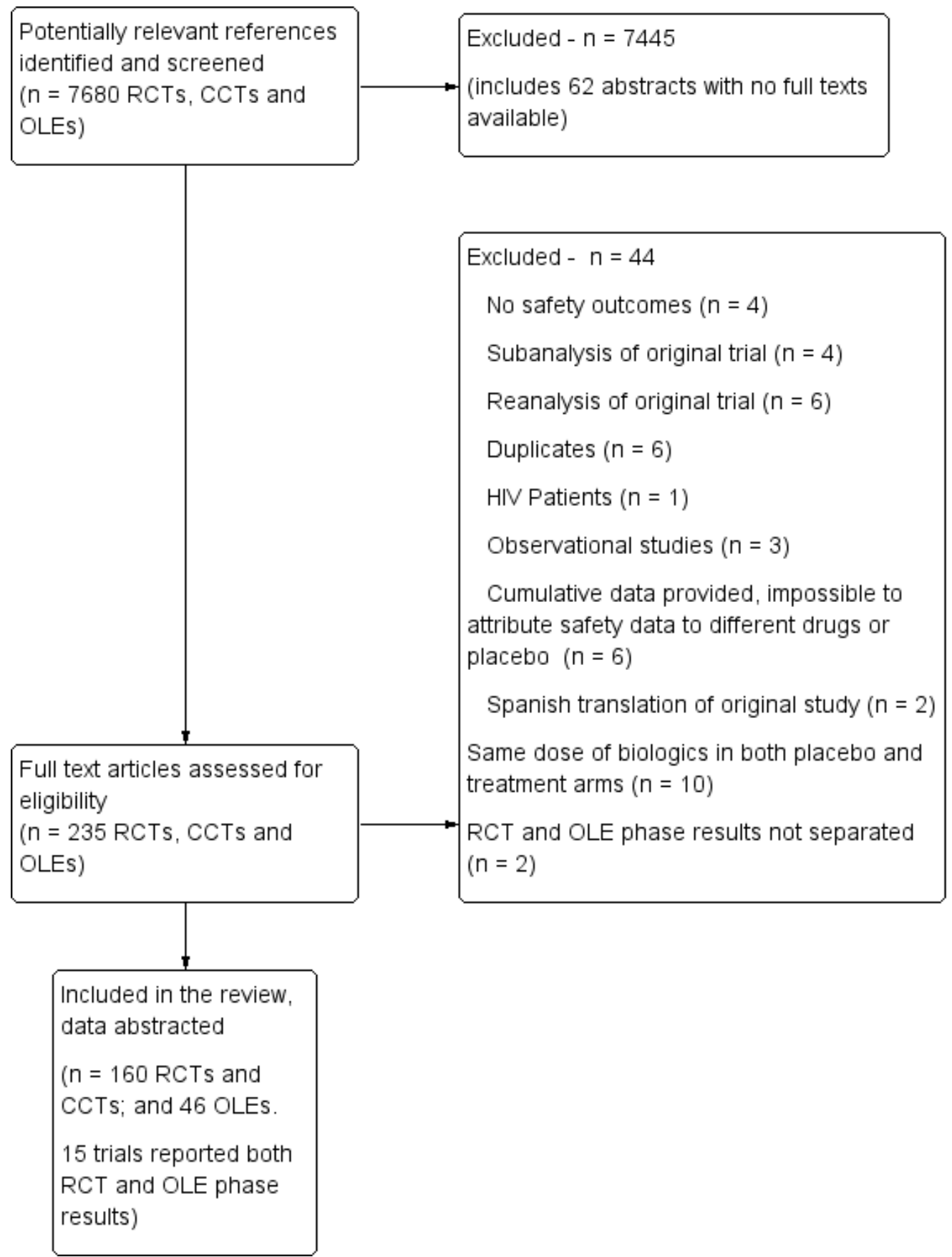

\section{Description of included reviews}

We included a total of 160 RCTs with 48,676 participants and 46 OLEs with 11,954 participants in this review. Four CCTs were found and analyzed with the RCT data. The median duration of the RCTs was six months and the majority of the RCTs assessed etanercept or infliximab in people with RA or cancer. Table 2 provides further details on the characteristics of the included studies.

\section{Concordance of assessment of included studies}

There were 10 review groups each providing two review authors. The articles were randomly distributed to the review groups and the articles within a review group were assessed independently by each of the two review authors and consensus was obtained. To evaluate agreement across the 10 review groups, two articles were assessed by each of the groups who were unaware that these two articles were being assessed across the groups for quality assurance purposes. The results of this assessment indicated a high degree of agreement with the safety data being extracted, with concordance; the kappa exceeded 0.9 and the only area of discrepancy concerned the assessment of the risk of bias. 


\section{Methodological quality of included reviews}

We presented summaries of the methodological quality of the included studies for each of the domains we assessed. Results are presented separately for RCTs and OLEs. Details on the judgement for each included study and the reason for that judgement are available at the following website: Cochrane Musculoskeletal Group website.

\section{Randomized controlled trials}

Allocation sequence: 45 of 160 RCTs (28.1\%) reported adequate methods for allocation sequence and were judged to be at low risk of bias. One hundred and twelve RCTs $(70 \%)$ did not provide enough information to assess allocation sequence and the risk of bias was judged to be unclear for these studies. Three of the RCTs (1.9\%), reported inadequate methods for allocation concealment including biased coin assignment (Menter 2007), simple block randomization (Pavelka 2009), and sequential allocation (Cassano 2006). These three studies were judged to be at high risk of bias for allocation sequence.

Allocation concealment: 60 of 160 RCTs (37.5\%) reported adequate methods for allocation concealment and were judged to be at low risk of bias. Ninety-six RCTs (60\%), did not provide enough information to assess allocation concealment and the risk of bias was judged to be unclear for these studies. Four studies (2.5\%) were judged to be at high risk of bias for allocation concealment. Three of these RCTs were open-label studies ( Buske 2009; Eve 2009; Hiddemann 2005) and one study used sequential allocation to assign patients to treatment (Cassano 2006).

Blinding of personnel: 65 of 160 RCTs (40.6\%) reported adequate methods for blinding personnel to treatment allocation. Seventyeight RCTs (48.8\%) did not provide enough information to assess the blinding of personnel and the risk of bias was judged to be unclear for these studies. Seventeen studies (10.6\%) were judged to be at high risk of bias for blinding of personnel. Nine of these RCTs were open-label studies (Buske 2009; Coiffier 1998; Eve 2009; Forstpointner 2002; Forstpointner 2004; Herold 2007; Hiddemann 2005; Ortonne 2008; Salles 2007;), no blinding was reported in one study (Hainsworth 2005), unmasking or unblinding was reported in four studies (Genovese 2002a; Kavanaugh 2000; Pavelka 2009; Pfreundschuh 2006). Patients and doctors were aware of treatment allocation in the Van Vollenhoven 2009 study. In the Schrieber 2005 study the treatment and placebo looked different. In the Van der Bijl 2009 study, injections were given by a non-blinded independent investigator.

Blinding of participants: 75 of $160 \mathrm{RCTs}(46.9 \%)$ reported adequate methods for blinding participants to treatment allocation. Sixtynine RCTs (43.1\%) did not provide enough information to assess the blinding of participants and the risk of bias was judged to be unclear for these studies. Sixteen studies $(10 \%)$ were judged to be at high risk of bias for blinding of participants. Nine of these RCTs were open-label studies (Buske 2009; Coiffier 1998; Eve 2009; Forstpointner 2002; Forstpointner 2004; Herold 2007; Hiddemann 2005; Ortonne 2008; Salles 2007); no blinding was reported in one study (Hainsworth 2005), unmasking or unblinding was reported in two studies (Genovese 2002a; Pfreundschuh 2006). Patients were aware of treatment allocation in three studies (Cassano 2006; Durez 2007; Van Vollenhoven 2009). In the Schrieber 2005 study the treatment and placebo were of a different color and viscosity.
Blinding of outcome assessors: 61 of 160 RCTs (38.1\%) reported adequate methods for blinding outcome assessors to treatment allocation. Ninety RCTs (56.3\%) did not provide enough information to assess the blinding of outcome assessors and the risk of bias was judged to be unclear for these studies. Nine studies (5.6\%) were judged to be at high risk of bias for blinding of outcome assessors. Six of these RCTs were open-label studies (Coiffier 1998; Eve 2009; Forstpointner 2004; Herold 2007; Hiddemann 2005; Ortonne 2008), no blinding was reported in one study (Hainsworth 2005), and unmasking or unblinding was reported in two studies (Genovese 2002a; Pfreundschuh 2006).

Incomplete outcome data: the majority of included studies (115 of $160 ; 71.9 \%$ ) were judged to be at a low risk of bias. In these trials, missing outcome data were less than $20 \%$ and balanced in numbers across intervention groups with similar reasons for missing data across groups. Analysis was either by intention-to-treat or safety analysis, including all patients receiving at least one dose of study drug. In 25 trials (15.6\%), the flow of patients was not fully reported or more than $20 \%$ of patients dropped out, indicating a high risk of bias. In the remaining 20 studies (12.5\%), insufficient information about the flow of data within studies was reported so that it was uncertain whether or not the handling of incomplete data was appropriate. We judged risk of bias for these trials to be unclear.

Selective outcome reporting: the majority of included studies (102 of $160 ; 63.8 \%$ ) were judged to be at low risk of bias. The study protocols were not available but the published reports included all expected outcomes including important side effects and those outcomes that were pre-specified in the methods section. In 21 trials (13.1\%), risk of bias was judged to be high. In these trials, the majority of adverse events were not reported or it was impossible to assign them to the comparison groups. In 37 trials (23.1\%), there was insufficient information on adverse events to judge whether selective reporting occurred.

Major baseline imbalance: most included studies (137 of 160; $85.6 \%$ ) were judged to be at low risk of bias. The demographic and baseline characteristics of the study populations were generally similar and appeared to be balanced for all treatment groups. In eight studies (5\%), unequally distributed demographic or baseline characteristics were reported, indicating a high risk of bias. For 15 studies (9.4\%), no baseline measures were reported or insufficient information was given to make a judgement.

Serious adverse event definitions: in the majority of included studies (106 of $160 ; 66.2 \%$ ), insufficient information on serious AEs definition was given and we judged the risk of bias to be unclear. In the remaining 54 trials (33.8\%), a serious AE definition was provided and risk of bias was judged to be low.

Method of adverse event monitoring: most included trials (105 of $160 ; 65.6 \%$ ) reported that AEs were actively monitored. The risk of bias was therefore judged to be low. In 49 trials (30.6\%), insufficient information about the method of AE monitoring was reported so that it was uncertain whether or not adverse events were monitored appropriately. Risk of bias was judged to be unclear in these studies. In the remaining six trials (3.8\%), AEs were reported as they occurred indicating a high risk of bias. 


\section{Open-label extension studies (OLEs)}

Allocation sequence: all 46 OLEs were judged to be at high risk of bias for allocation sequence because there was no random assignment to the open-label treatment groups.

Allocation concealment: all 46 OLEs were judged to be at high risk of bias because there was no allocation concealment with respect to assignment to the open-label treatment groups.

Blinding of personnel: personnel were not blinded to treatment allocation in the 46 OLEs. These studies were judged to be at high risk of bias for blinding of personnel.

Blinding of participants: patients were not blinded to treatment allocation in 44 of 46 OLEs. These studies were judged to be at high risk of bias for blinding of participants. Gordon 2006b reported that patients who relapsed began receiving blinded etanercept treatment at the same dose they received at week 24 of the doubleblind period. Braun 2008a reported that patients remained blinded throughout the extension phase. These two studies were judged to be at low risk of bias for blinding of participants.

Blinding of outcome assessors: outcome assessors were not blinded to treatment allocation in 43 of 46 OLEs. These studies were judged to be at high risk of bias for blinding of outcome assessors. Three studies did not provide enough information to assess the blinding of outcome assessors and the risk of bias was judged to be unclear for these studies (Genovese 2008b; Gordon 2006a; Mease 2009). One study was judged to be at low risk of bias for blinding of outcomes assessors. Genovese 2002b reported that the readers remained blinded to treatment group assignment and chronological order.

Incomplete outcome data: just over half the studies (25/46; 54.3\%) were likely to be at high risk of attrition bias as more than $20 \%$ of participants dropped out. Some participants who were lost to follow-up may have had adverse events that were not included in the analyses, which could underestimate the adverse effect estimates. In 18 studies (39.1\%), the majority of participants ( $80 \%$ or more) contributed outcome data and thus we judged these studies to be at low risk of attrition bias. In the remaining three studies $(6.5 \%)$ the number of participants who were lost to followup was not reported, thus we were unclear if these studies were at risk of attrition bias.

Selective outcome reporting: we judged over half of the included studies ( 25 of $46 ; 54.3 \%$ ) to be at low risk of selective reporting bias. We did not check if study protocols were available but judged published reports to be at low risk of this type of reporting bias if they reported all expected outcomes, including important AEs and those outcomes pre-specified in the methods section. Ten $(21.7 \%)$ of 46 studies were likely to be at high risk of selective reporting bias because these studies either did not specify in the methods that they intended to report AEs or specified that only AEs that occurred in more than one participant were reported (for example Braun 2003). In 11 studies (23.9\%) there was insufficient information on the types of adverse events to judge whether selective reporting occurred or adverse events that are usually associated with the drug were not addressed.

Serious adverse event definitions: the majority of studies (29 of 46; 63\%) did not clearly define 'serious adverse events', thus we were unclear on the risk of bias for this domain in those studies. In the remaining 17 studies (36.9\%) the authors defined which adverse events were 'serious adverse events' and thus we judged these as having a low risk of bias.

Method of adverse event monitoring: we judged most studies (27 of $46 ; 58.6 \%$ ) to be at low risk of missing important adverse effect as they reported active monitoring of AEs during follow-up. Four studies (8.7\%) had a high risk of bias as they either reported AEs only as they occurred (Dijkmans 2009; Furst 2007; Haibel 2008) or, in one study, did not collect reports of non-serious adverse events for all of the open-label extension period of the study (Genovese $2005 b)$. The remaining 15 studies (32.6\%) reported insufficient information to judge if AEs were monitored appropriately or not.

\section{Effect of interventions}

We analyzed only the major outcomes of interest that were prespecified in our protocol as major outcomes and those presented in the 'Summary of findings' table (that is, the seven outcomes as recommended in Chapter 11 of the Cochrane Handbook for Systematic Reviews of Interventions (Higgins 2011). Minor outcomes were not analyzed in the Cochrane overview, since there were fewer studies providing data for these outcomes and the number of events was too low to allow meaningful comparisons. For example, data for allergic reaction was provided in 38 out of 160 RCTs, neurological adverse events in 31 RCTs, and fungal infections in 12. Only 25 patients in the biologic group versus 23 patients in the control group had fungal infections.

A summary of the risk estimates for each major outcome and the grading of the evidence are provided in Table 3 (overall biologics) and Table 4 (individual biologics).

\section{Results from randomized controlled trials}

The majority of included RCTs were of short duration with the median length being six months. Thus, all the results below should be interpreted as applying to a fairly short time frame (that is a few weeks to a few months).

The number of events for each of the four outcomes (SAEs, AEs, withdrawals due to $A E s$ and serious infections) are shown in Table 5.

Using the standard dose model with the Bayesian mixed treatment comparison approach, compared to control the biologics as a group were associated with a statistically significant higher rate of total AEs (odds ratio (OR) $1.28,95 \%$ credible interval (CI) 1.09 to 1.50 ; $\mathrm{P}=0.00013$ ) (Table 3; Figure 2), withdrawals due to AEs (OR 1.47, $95 \% \mathrm{Cl} 1.20$ to $1.86 ; \mathrm{P}=0.012$ ) (Table 3 ; Figure 3 ), serious infections (OR 1.37, 95\% Cl 1.04 to 1.82; $\mathrm{P}=0.015$ ) (Table 3; Figure 4), and an increased risk of TB reactivation (OR $4.68,95 \% \mathrm{Cl} 1.18$ to $18.60 ; \mathrm{P}=$ 0.028) (Table 3). 
Figure 2. Forest plot of network meta-analysis: total adverse events

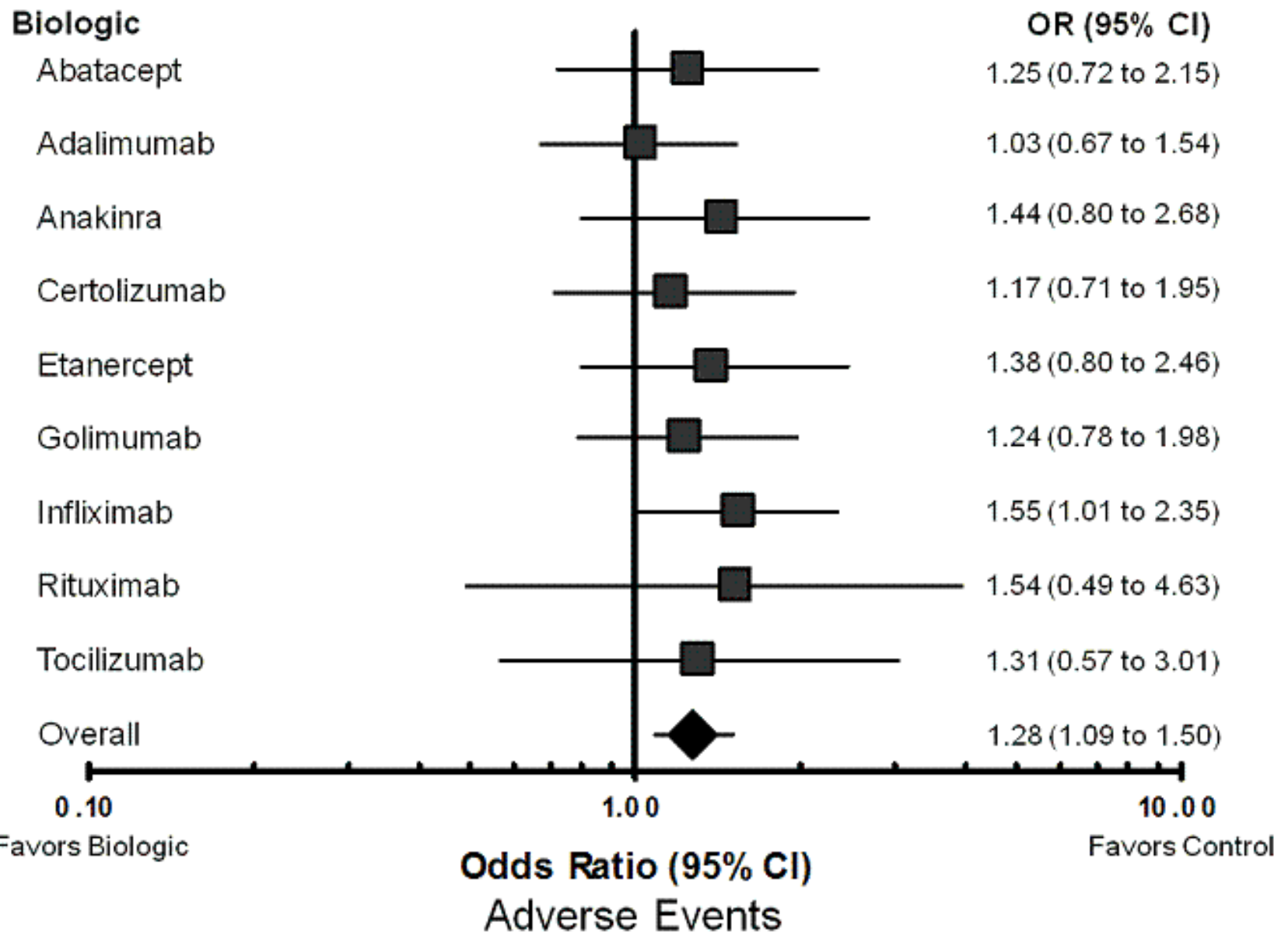


Figure 3. Forest plot of network meta-analysis: withdrawals due to adverse events

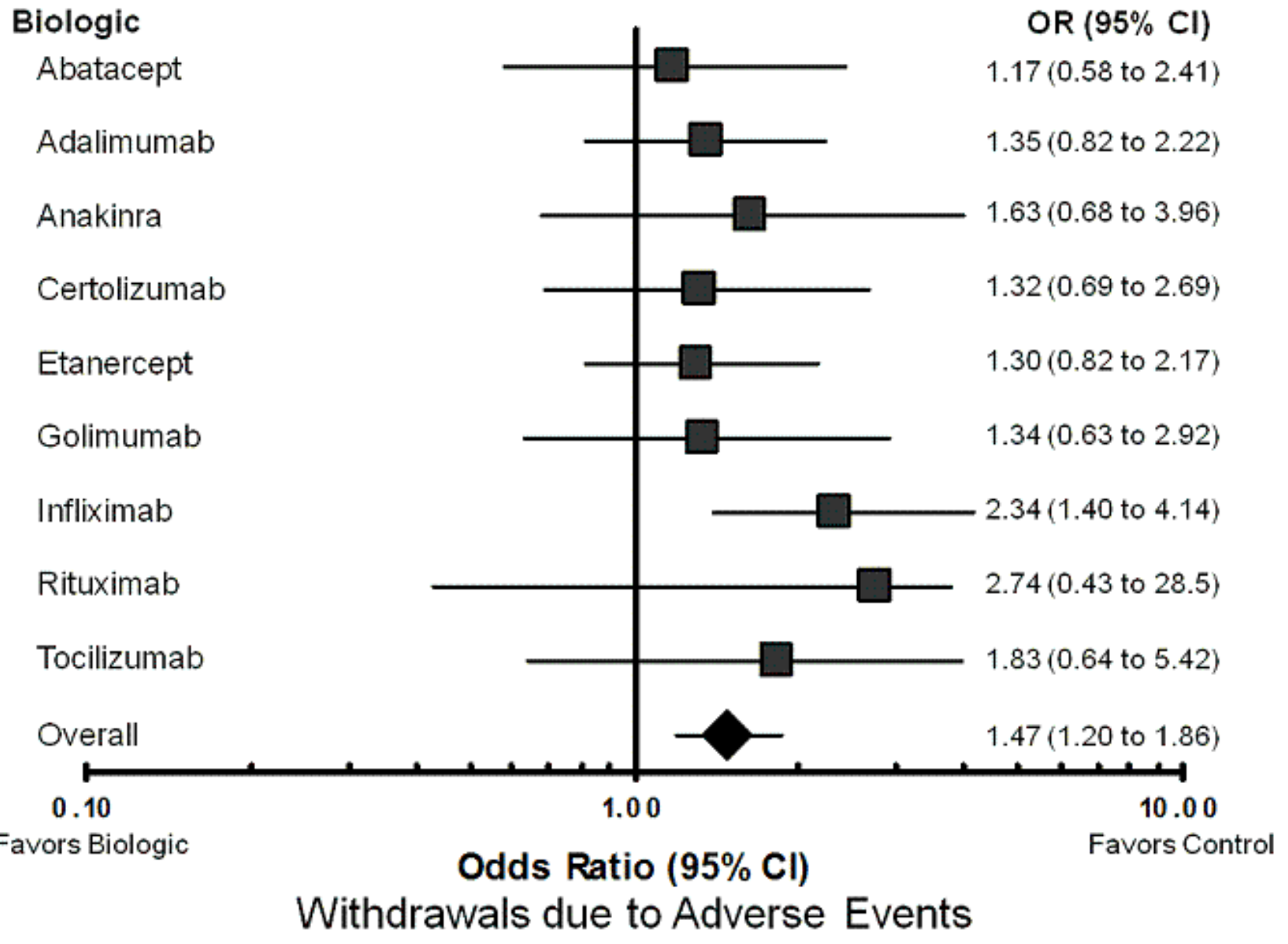


Figure 4. Forest plot of network meta-analysis: serious infections

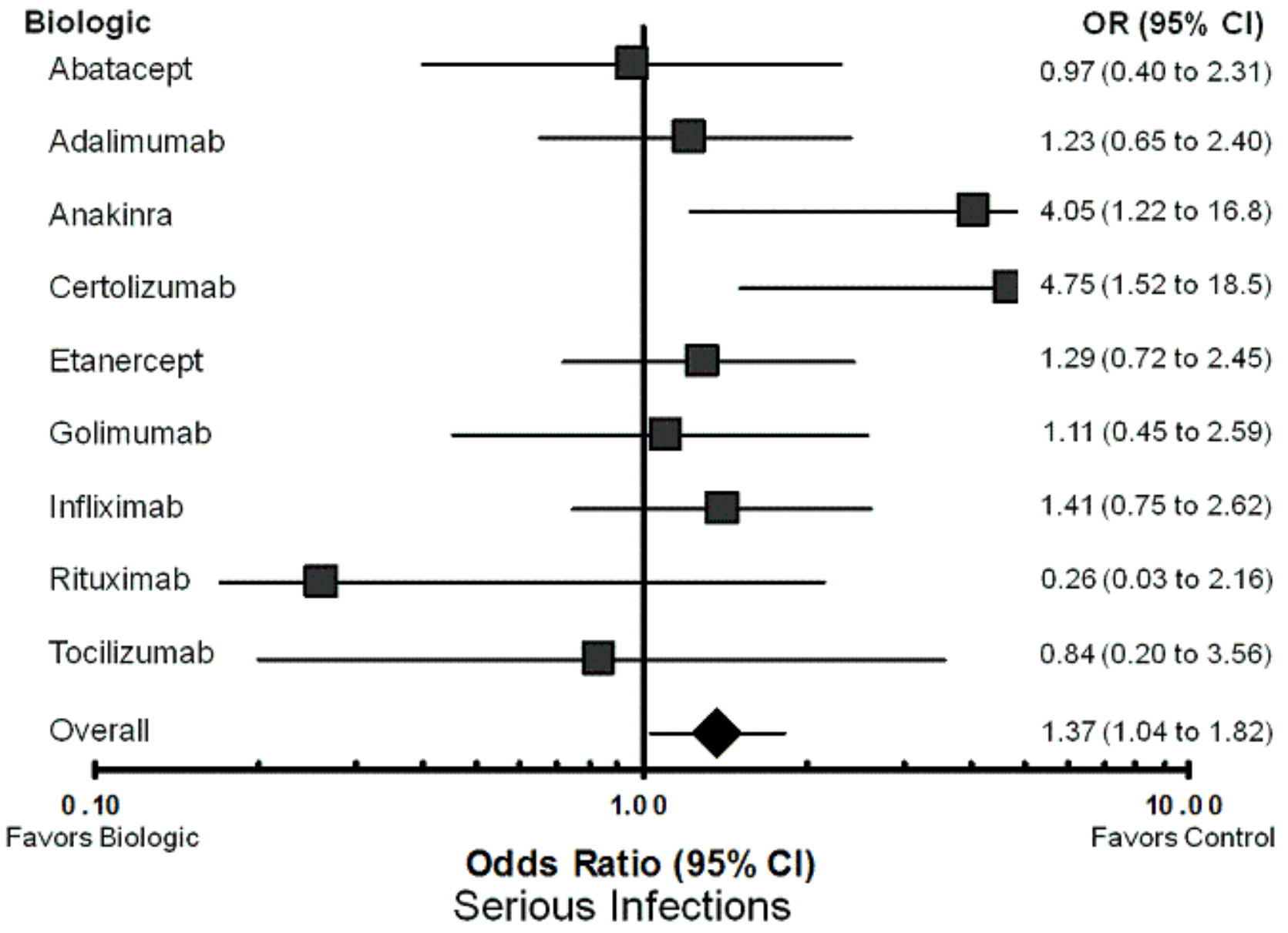

The rate of serious adverse events (OR 1.09, 95\% Cl 0.97 to $1.24 ; \mathrm{P}=$ 2.69; $\mathrm{P}=0.60)$ (Table 3) were not statistically significantly different 0.20 ) (Table 3; Figure 5), lymphoma (OR $0.53,95 \% \mathrm{Cl} 0.17$ to $1.66 ; \mathrm{P}=$ 0.27 ) (Table 3), and congestive heart failure (OR $0.69,95 \% \mathrm{Cl} 0.18$ to between biologics and control treatment. 
Figure 5. Forest plot of network meta-analysis: serious adverse events

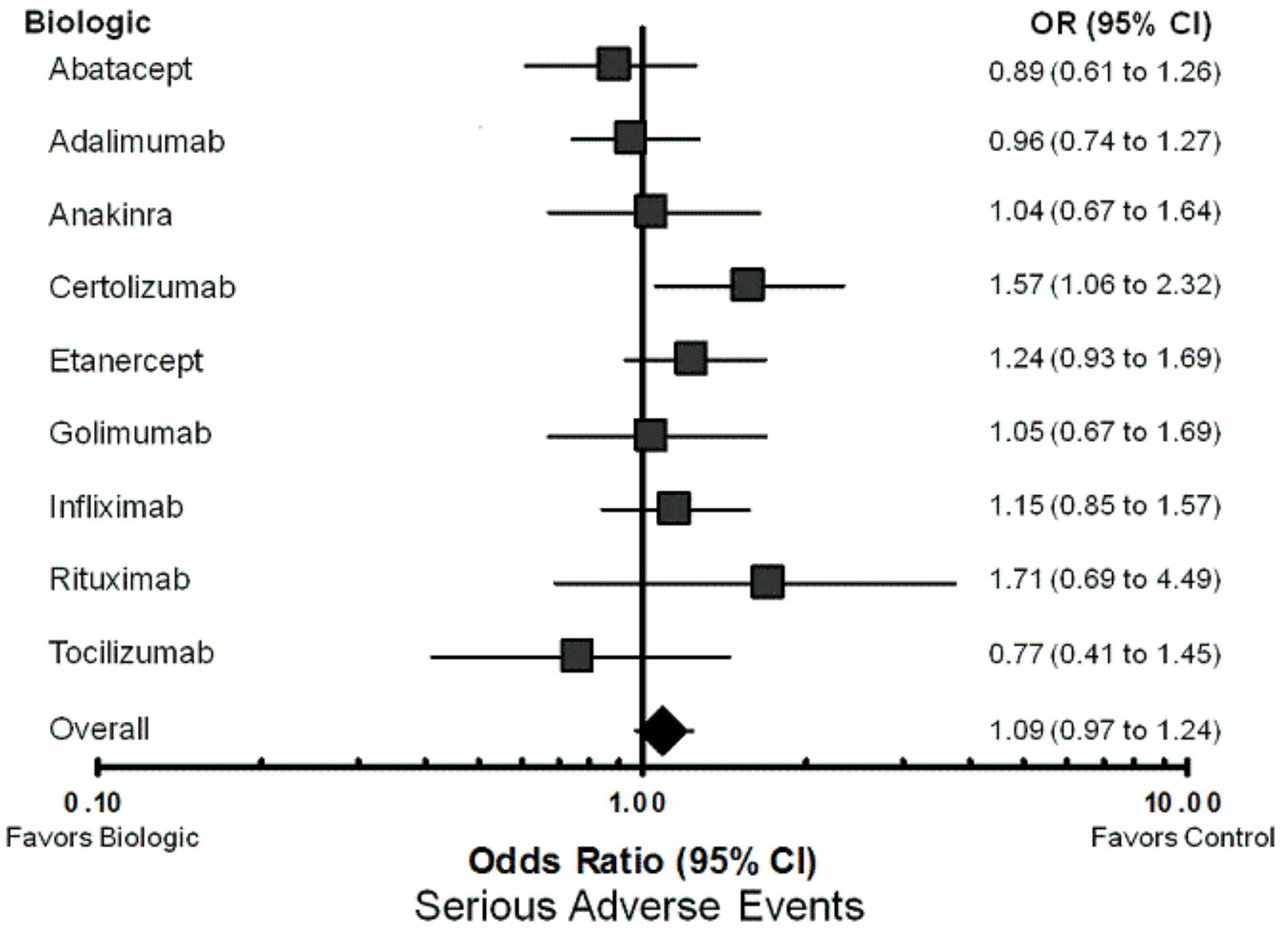

The results of standard meta-analyses were similar to those from the Bayesian models described above (Table 6; Figure 6) In particular, the odds ratio estimates were very similar. 
Figure 6. Forest plots of standard meta-analyses

\section{6a. Serious adverse events}

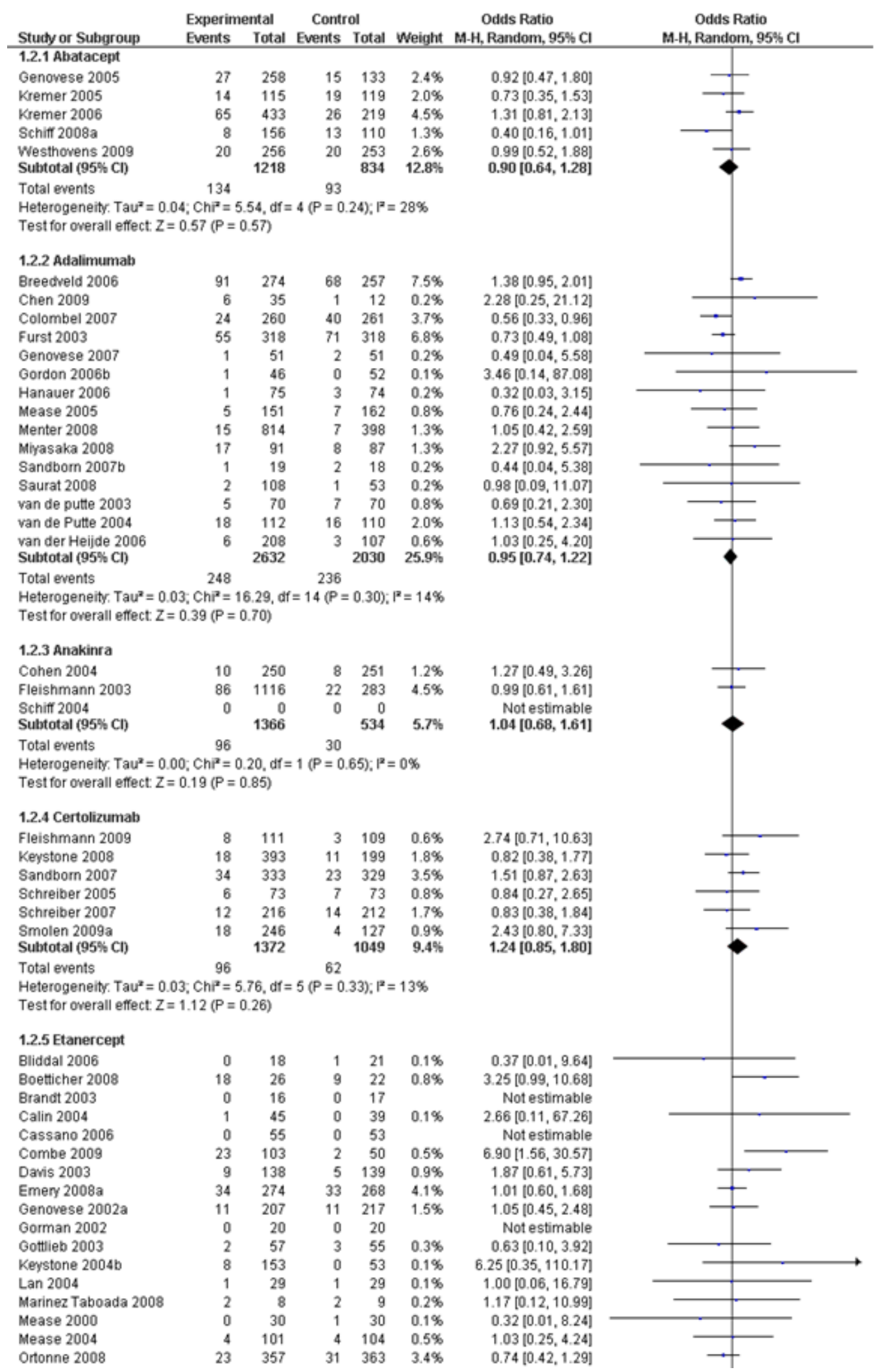


Figure 6. (Continued)

\begin{tabular}{|c|c|c|c|c|c|}
\hline - & $=$ & $\ldots$ & . & $\ldots$ & $\cdots$ \\
\hline Mease 2004 & 4 & 101 & 4 & 104 & $0.5 \%$ \\
\hline Ortonne 2008 & 23 & 357 & 31 & 363 & $3.4 \%$ \\
\hline Rouhani 2005 & 1 & 12 & 2 & 9 & $0.2 \%$ \\
\hline Sandborn 2001 & 1 & 23 & 2 & 20 & $0.2 \%$ \\
\hline van der Heijde 2006 & 8 & 155 & 2 & 51 & $0.4 \%$ \\
\hline Weisman 2007 & 31 & 266 & 26 & 269 & $3.5 \%$ \\
\hline Subtotal $(95 \% \mathrm{Cl})$ & & 2093 & & 1838 & $17.1 \%$ \\
\hline Total events & 177 & & 135 & & \\
\hline \multicolumn{6}{|c|}{$\begin{array}{l}\text { Heterogeneity. Tau }=0.00 ; \mathrm{Chi}^{2}=16.86, \mathrm{df}=17(P=0.46) ; \mathrm{I}^{2}=0 \% \\
\text { Test for overall effect: } Z=0.91(P=0.36)\end{array}$} \\
\hline \multicolumn{6}{|l|}{ 1.2.6 Golimumab } \\
\hline Emery 2009 & 10 & 159 & 11 & 160 & $1.4 \%$ \\
\hline Inman 2008 & 5 & 138 & 4 & 77 & $0.6 \%$ \\
\hline Kavanaugh 2009 & 3 & 146 & 7 & 113 & $0.6 \%$ \\
\hline Kay 2008 & 4 & 37 & 2 & 34 & $0.4 \%$ \\
\hline Keystone 2009 & 5 & 89 & 3 & 133 & $0.5 \%$ \\
\hline Smolen 2009b & 8 & 153 & 11 & 155 & $1.2 \%$ \\
\hline Wenzel 2009 & 24 & 77 & 16 & 78 & $2.0 \%$ \\
\hline Zhou 2007 & 0 & 5 & 0 & 10 & \\
\hline Subtotal $(95 \% \mathrm{Cl})$ & & 804 & & 760 & $6.7 \%$ \\
\hline Total events & 59 & & 54 & & \\
\hline
\end{tabular}

Heterogeneity. Tau $^{2}=0.09 ; C h r^{2}=7.81, \mathrm{df}=6(P=0.25) ; I^{2}=23 \%$

Test for overall effect: $Z=0.16(P=0.87)$

\subsubsection{Infiximab}

\begin{tabular}{|c|c|}
\hline Abe 2006 & 0 \\
\hline Durez 2007 & 1 \\
\hline Gottlieb 2004 & 4 \\
\hline Maini 1999 & 8 \\
\hline Mariette 2004 & 6 \\
\hline Menter 2007 & 3 \\
\hline Pavelka 2009 & 11 \\
\hline Rennard 2007 & 15 \\
\hline Salvarani 2007 & 4 \\
\hline Schiff 2008b & 19 \\
\hline St Clair 2004 & 52 \\
\hline van Vollenhoven 2009 & 1 \\
\hline Westhovens 2006 & 28 \\
\hline Wiedenmann 2008 & 13 \\
\hline Subtotal $(95 \% \mathrm{Cl})$ & \\
\hline
\end{tabular}

Subtotal $(95 \% \mathrm{Cl})$

Total events

49
15
99
86
54
313
69
78
23
165
373
128
360
28
1840

$1470.1 \%$

$0 \quad 140.1 \%$

$0 \quad 51 \quad 0.1 \%$

$1488 \quad 1.3 \%$

$1 \quad 49 \quad 0.2 \%$

$3207 \quad 0.4 \%$

$1271 \quad 1.4 \%$

$\begin{array}{lll}16 & 77 & 1.8 \%\end{array}$

$\begin{array}{lll}0 & 28 & 0.1 \% \\ 13 & 1 & 0\end{array}$

$131101.9 \%$

$32 \quad 298 \quad 4.8 \%$

$1130 \quad 0.1 \%$

$27 \quad 363 \quad 3.6 \%$

$16 \quad 30 \quad 1.0 \%$ 136

Heterogeneity, $\operatorname{Tau}^{2}=0.00 ; \mathrm{Ch}^{2}=11.31, \mathrm{df}=13(\mathrm{P}=0.58) ; \mathrm{I}^{2}=0 \%$

Test for overall effect: $Z=0.46(P=0.65)$

\subsubsection{Rituximab}

Emery 2006

Hauser 2008

Subtotal (95\% CD)

Total events

9

18

$\begin{array}{rrrr}124 & 4 & 149 & 0.8 \% \\ 69 & 5 & 35 & 0.8 \% \\ 193 & & 184 & 1.5 \%\end{array}$

$2.84(0.85,9.45)$

$0.90[0.28,2.92]$ $1.59[0.51,4.89]$

$0.31[0.01,7.88]$ $3.00[0.11,79.91]$ $4.85[0.26,91.93]$ $0.54[0.21,1.37]$ $6.00[0.70,51.74]$ $0.66[0.13,3.29]$ $0.93[0.38,2.28]$ $0.91[0.41,2.00]$

$13.15[0.67,258.45]$ $0.97[0.46,2.06]$

$1.35[0.84,2.15$

$1.02[0.06,16.42]$

$1.05[0.61,1.82]$

$0.76[0.27,2.13]$

$1.06[0.82,1.37]$

Test for overall effect: $Z=0.80(P=0.42)$

\subsubsection{Tocilizumab}

$\begin{array}{lrrrrr}\text { Emery 2008b } & 12 & 163 & 18 & 160 & 1.9 \% \\ \text { Maini 2006 } & 5 & 54 & 2 & 49 & 0.4 \% \\ \text { Smolen 2008 } & 13 & 212 & 12 & 204 & 1.7 \\ \text { Subtotal (95\% Cl) } & & 429 & & \mathbf{4 1 3} & 3.9\end{array}$

Total events

Heterogeneity. Tau $^{2}=0.04 ; \mathrm{ChI}^{2}=2.28, \mathrm{df}=2(P=0.32) ; \mathrm{I}^{2}=12 \%$

Test for overall effect: $Z=0.34(P=0.74)$

$\begin{array}{lccccc}\text { Total }(95 \% \mathrm{CD}) & 11947 & & 9205 & 100.0 \% \\ \text { Total events } & 1023 & & 787 & \end{array}$

Heterogeneity. Tau $^{2}=0.00 ; \mathrm{Ch}^{2}=71.57, \mathrm{df}=71(\mathrm{P}=0.46) ; \mathrm{I}^{2}=1 \%$ Test for overall effect: $Z=0.75(P=0.46)$

Test for subaroup differences: $\mathrm{Ch}^{\mathrm{P}}=3.10 . \mathrm{df}=8(\mathrm{P}=0.93), \mathrm{P}=0 \%$

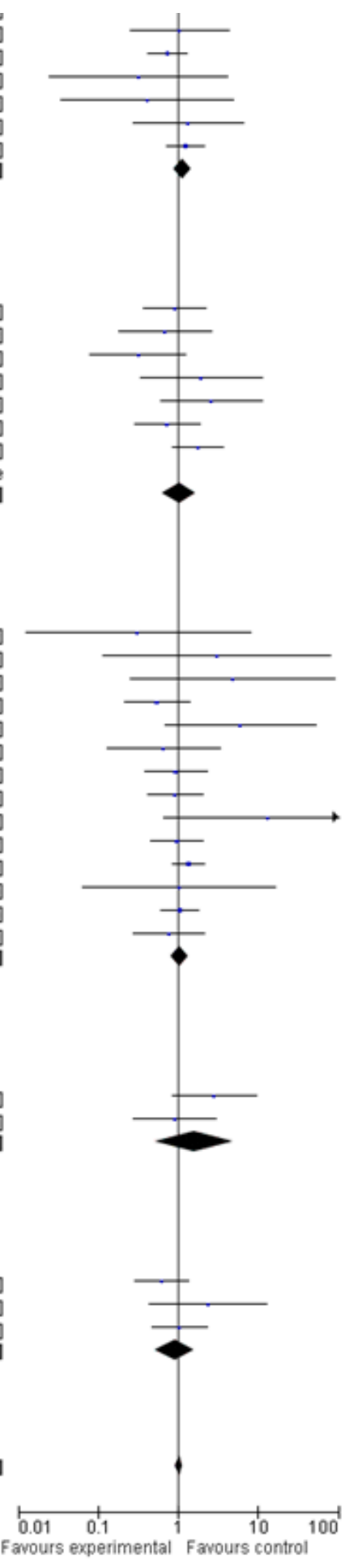

\section{6b. Total adverse events}

\begin{tabular}{|c|c|c|c|c|c|c|c|}
\hline \multirow{2}{*}{ Stucty or Subgroup } & \multicolumn{2}{|c|}{ Experimental } & \multicolumn{2}{|c|}{ Control } & \multirow[b]{2}{*}{ Weight } & \multirow{2}{*}{$\begin{array}{c}\text { Odds Ratio } \\
\text { M- } \mathrm{H}, \text { Random, } 95 \% \mathrm{Cl}\end{array}$} & \multirow{2}{*}{$\begin{array}{l}\text { Odds Ratio } \\
\text { M-H, Random, } 95 \% \mathrm{Cl}\end{array}$} \\
\hline & Events & Total & Events & Total & & & \\
\hline Genovese 2005 & 205 & 258 & 95 & 133 & $2.9 \%$ & $1.55[0.96,2.51]$ & - \\
\hline
\end{tabular}


Figure 6. (Continued)

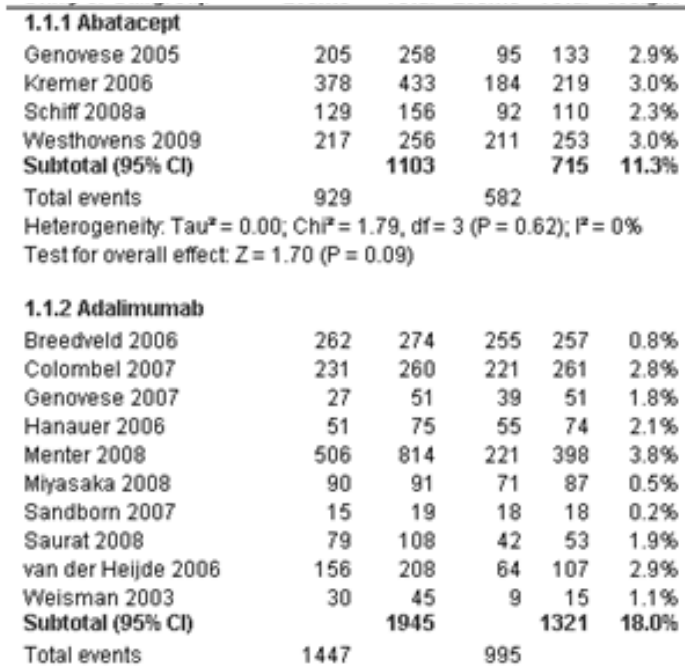

Heterogeneity, Tau $^{2}=0.31 ; \mathrm{ChP}^{2}=33.51, \mathrm{df}=9(\mathrm{P}=0.0001) ; \mathrm{P}^{\mathrm{P}}=73 \%$ Test for overall effect: $Z=0.03(P=0.97)$

\subsubsection{Anakinra}

Cohen 2002

Cohen 2004

Fleishmann 2003

Schiff 2004

Subtotal $(95 \% \mathrm{Cl})$

Total events

Heterogeneity. Tau $^{2}=0.25 ; \mathrm{ChP}^{2}=6.46, \mathrm{df}=2(\mathrm{P}=0.04) ; \mathrm{P}^{2}=69 \%$

Test for overall effect: $Z=1.46(P=0.14)$

\subsubsection{Certolizumat}

Fleishmann 2009

Sandobm 2007

Schreiber 2005

Schreiber 2007

Smolen 2009a

Subtotal $(95 \% \mathrm{Cl})$

Total events

\begin{tabular}{|c|c|c|c|}
\hline 8 & 59 & 3 & 74 \\
\hline 225 & 250 & 203 & 251 \\
\hline 1027 & 1116 & 261 & 283 \\
\hline 0 & $\begin{array}{r}0 \\
1425\end{array}$ & 0 & $\begin{array}{r}0 \\
608\end{array}$ \\
\hline 1260 & & 467 & \\
\hline
\end{tabular}

Heterogeneity. Tau $^{2}=0.06 ; \mathrm{ChP}^{2}=7.85, \mathrm{df}=4(P=0.10) ; \mathrm{P}^{2}=49 \%$

Test for overall effect: $Z=0.98(P=0.33)$

\subsubsection{Etanercept}

Bliddal 2006

Brandt 2003

Emery 2008a

Marinez Taboada 2008

Ortonne 2008

Sandborn 2001

van der Heijde 2006

Subtotal $(95 \% \mathrm{Cl})$

Total events

$\begin{array}{lllll}84 & 111 & 63 & 109 & 2.6 \%\end{array}$

$\begin{array}{lllll}269 & 333 & 260 & 329 & 3.3 \%\end{array}$

$\begin{array}{lllll}48 & 73 & 51 & 73 & 2.2 \%\end{array}$

$\begin{array}{lllll}140 & 216 & 143 & 212 & 3.3 \%\end{array}$

$\begin{array}{rrrrr}140 & 216 & 143 & 212 & 3.3 \% \\ 139 & 246 & 66 & 127 & 3.1 \%\end{array}$

\begin{tabular}{l}
$979-850 \quad 14.58$ \\
\hline
\end{tabular} 583

Heterogeneity. $\operatorname{Tau}^{2}=0.00 ; \mathrm{Ch}^{2}=5.59, \mathrm{df}=6(\mathrm{P}=0.47) ; \mathrm{I}^{2}=0 \%$

Test for overall effect: $Z=1.00(P=0.32)$

\subsubsection{Golimumab}

Emery 2009

Inman 2008

Kavanaugh 2009

Kay 2008

Smolen 2009b

Zhou 2007

Subtotal $(95 \% \mathrm{Cl})$

Total events

$\begin{array}{rrrrr}1 & 18 & 1 & 21 & 0.3 \% \\ 8 & 16 & 6 & 17 & 0.9 \% \\ 246 & 274 & 247 & 268 & 2.5 \% \\ 8 & 8 & 7 & 9 & 0.2 \% \\ 281 & 357 & 273 & 363 & 3.5 \% \\ 17 & 23 & 10 & 20 & 1.0 \% \\ 55 & 155 & 18 & 51 & 2.3 \% \\ & 851 & & 749 & 10.7 \% \\ 616 & & 562 & & \end{array}$

$18[0.07,20.26]$

$1.83(0.45,7.41)$

$0.75[0.41,1.35]$

$27[1.28,4.04]$

$0.83[0.41,1.66]$

$0.89[0.60,1.33)$

$1.20[0.78,1.85]$

$1.16[0.86,1.56]$

$5.67[0.23,137.80]$

$1.22(0.86,1.73)$

$2.83[0.79,10.17]$

$1.01[0.52,1.95]$

$1.14[0.88,1.48]$

$1.63[0.96,2.76]$

$1.45[0.87,2.41]$

$1.95(0.43,8.89)$

$0.67[0.42,1.08]$

$9.33[0.71,122.57]$

$1.30[0.85,1.99]$

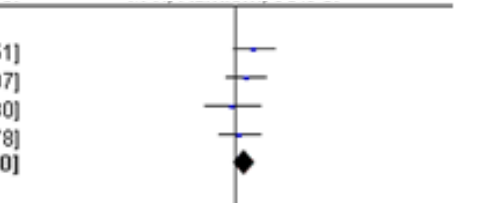

Heterogeneity. Tau $^{2}=0.13 ; \mathrm{Ch}^{2}=10.54$, df $=5(P=0.06) ; \mathbb{P}^{2}=53 \%$

Test for overall effect: $Z=1.22(P=0.22)$

1.1.7 Infliximab

$\begin{array}{lrrrrrr}\text { Gottlieb } 2004 & 76 & 99 & 32 & 51 & 2.1 \% & 1.96[0.94,4.09]\end{array}$

Menter 2007

$\begin{array}{lllll}196 & 313 & 58 & 207 & 3.3 \%\end{array}$

$4.30[2.94,6.29]$ 
Figure 6. (Continued)

Test for overall effect: $Z=1.02(P=0.31)$

\subsubsection{Anakinr}

Cohen 2002

Cohen 2004

Fleishmann 2003

Subtotal (95\% Cl)

Total events

Heterogeneity. Tau $^{2}=1.67 ; \mathrm{Chi}^{2}=6.57$, df $=1(P=0.01) ; P^{2}=85 \%$

Test for overall effect: $Z=0.43(P=0.67)$

\subsubsection{Certolizumab}

$\begin{array}{lrrrrr}\text { Fleishmann 2009 } & 5 & 111 & 2 & 109 & 1.0 \% \\ \text { Keystone 2008 } & 17 & 393 & 3 & 199 & 1.5 \% \\ \text { Sandobm 2007a } & 36 & 333 & 39 & 329 & 3.7 \% \\ \text { Schreiber 2005 } & 7 & 73 & 7 & 73 & 1.8 \% \\ \text { Schreiber 2007 } & 18 & 216 & 28 & 212 & 3.2 \% \\ \text { Smolen 2009a } & 12 & 246 & 2 & 127 & 1.1 \% \\ \text { Subtotal (95\% Cl) } & & 1372 & & 1049 & \mathbf{1 2 . 3 \%} \\ \text { Total events } & 95 & 81 & \end{array}$

Total events

$h_{i}^{2}=9.26, d f=5(P=0.10) ; P^{2}=46 \%$

Test for overall effect: $Z=0.57(P=0.57)$

\subsubsection{Etanercept}

Bliddal 2006

Boetticher 2008

Brandt 2003

Cassano 2006

Combe 2009

Davis 2003

Emery 2008a

Foster 2003

Genovese 2002a

Gorman 2002

Gottlieb 2003

Klareskog 2004

Lan 2004

Marinez Taboada 2008

Mease 2004

Moreland 1999

Ortonne 2008

Papp 2005

Rouhani 2005

Sandbom 2001

van der Heijde 2006

van der Heijde 2007

Weinblatt 1999

Weisman 2007

Zen 2005

Subtotal $(95 \% \mathrm{Cl})$

Total events

Heterogeneity Tau $^{2}=0.05 ; \mathrm{Chi}^{2}=20.59, \mathrm{df}=18(\mathrm{P}=0.30) ; \mathrm{P}^{2}=13 \%$

Test for overall effect: $Z=0.15(P=0.88)$

\subsubsection{Golimumab}

Emery 2009

Inman 2008

Kavanaugh 2009

Kay 2008

Keystone 2009

Smolen 2009b

Wenzel 2009

Subtotal $(95 \% \mathrm{Cl})$

Total events

Total events $\left.\quad{ }^{35} \quad 26 \quad 20.11\right) ;\left.\right|^{2}=41 \%$

Test for overall effect: $Z=0.58(P=0.56)$

\subsubsection{Infliximab}

Abe 2006

Durez 2007

Gottlieb 2004

Maini 1998

Mariette 2004

Menter 2007

Pavelka 2009

Rennard 2007 $\begin{array}{llll}159 & 5 & 160 & 1.9 \%\end{array}$

$\begin{array}{rrrr}138 & 1 & 77 & 0.6 \% \\ 146 & 4 & 113 & 0.9 \%\end{array}$

$\begin{array}{llll}37 & 2 & 34 & 0.9 \%\end{array}$

$\begin{array}{llll}89 & 4 & 133 & 0.9 \%\end{array}$

$\begin{array}{llll}53 & 9 & 155 & 1.6 \%\end{array}$

$\begin{array}{rrrr}77 & 1 & 78 & 0.7 \% \\ 99 & & 750 & 7.5 \%\end{array}$

$\begin{array}{rr}12 & 159 \\ 4 & 13 \\ 2 & 14 \\ 4 & 37 \\ 2 & 89 \\ 4 & 153 \\ 7 & 77 \\ & 79\end{array}$

$\begin{array}{rrr}1 & 49 \\ 1 & 15 \\ 7 & 99 \\ 0 & 14 \\ 6 & 54 \\ 13 & \\ 4 & 69 \\ 22 & 78\end{array}$

$\begin{array}{rrrr}49 & 1 & 47 & 0.4 \% \\ 15 & 0 & 14 & 0.3 \% \\ 99 & 1 & 51 & 0.7 \% \\ 14 & 0 & 14 & \\ 54 & 1 & 49 & 0.6 \% \\ 2 & 2 & 207 & \\ 69 & 5 & 71 & 1.3 \% \\ 78 & 6 & 77 & 2.1 \%\end{array}$

0.22 [0.05, 0.93] Not estimable $1.53[0.99,2.38]$ $0.65[0.09,4.50]$

$2.52[0.48,13.29]$ $2.95[0.86,10.20]$ $0.90[0.56,1.46]$ $1.00[0.33,3.01]$ $0.60[0.32,1.12]$

$3.21[0.71,14.55]$ 1.17 $[0.69,1.97]$

Not estimable $9.00[0.46,177.12]$ Not estimable Not estimable $1.24[0.37,4.16]$ $7.37[0.90,60.76]$ 0.78 [0.46, 1.33] $6.18[0.26,146.78]$ $0.55[0.28,1.07]$ Not estimable $0.30[0.06,1.54]$ $0.77[0.44,1.35]$ $1,00[0.06,16.79]$ $1.14[0,06,21.87]$ $1.03[0.06,16.69]$ $0.68[0.11,4.16]$ $1.88[0.96,3.67]$ $1.48[0.25,8.98]$ $2.48[0.09,68.14]$ $4.77[0.22,105.41]$

$4.48[0.25,80.89]$ Not estimable Not estimable $0.76[0.36,1.60]$ $2.09[0.18,24.61]$ $0.98[0.73,1.32]$

$2.53[0.87,7.36]$ $2.27[0.25,20.67]$ $0.38[0.07,2.10]$ $1.94[0.33,11.34]$ $0.74[0.13,4.14]$ $0.44[0.13,1.45]$ $7.70[0.92,64.16]$ $1.26[0.57,2.79]$

$0.96[0.06,15.78]$ 3.00 [0.11, 79.91] $3.80[0.46,31.80]$ Not estimable $6.00[0.70,51.74]$ Not estimable $0.81[0.21,3.16)$ $4.65[1.77,12.24]$

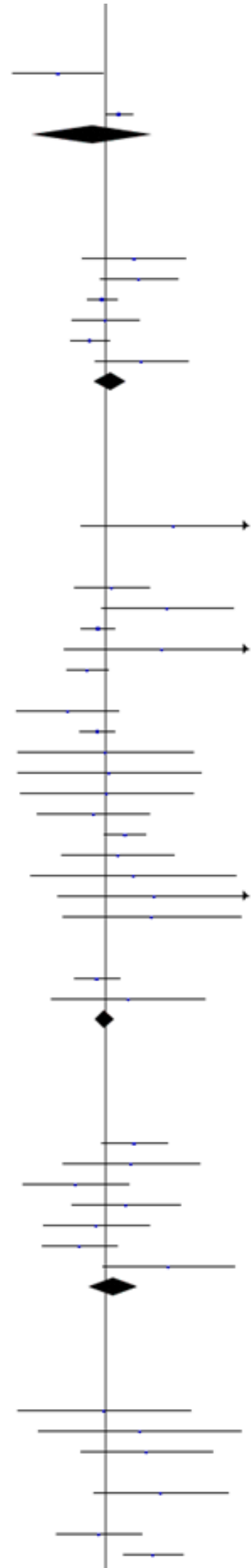


Figure 6. (Continued)

\begin{tabular}{|c|c|c|c|c|c|}
\hline & & 2 & & sur & \\
\hline Pavelka 2009 & 4 & 69 & 5 & 71 & $1.3 \%$ \\
\hline Rennard 2007 & 22 & 78 & 6 & 77 & $2.1 \%$ \\
\hline Salvarani 2007 & 2 & 23 & 0 & 28 & $0.3 \%$ \\
\hline Schirf 2008b & 8 & 165 & 1 & 110 & $0.7 \%$ \\
\hline St Clair 2004 & 34 & 373 & 9 & 298 & $2.7 \%$ \\
\hline Uppal 2009 & 4 & 9 & 0 & 18 & $0.3 \%$ \\
\hline van Vollenhoven 2009 & 10 & 128 & 14 & 130 & $2.4 \%$ \\
\hline Westhovens 2006 & 8 & 360 & 18 & 363 & $2.4 \%$ \\
\hline Wiedenmann 2008 & 7 & 28 & 6 & 30 & $1.5 \%$ \\
\hline Subtotal $(95 \% \mathrm{Cl})$ & & 1466 & & 1507 & $15.8 \%$ \\
\hline Total events & 127 & & 64 & & \\
\hline \multicolumn{6}{|c|}{$\begin{array}{l}\text { Heterogeneity: } \text { Tau }^{2}=0.69 ; C^{2}=29.96, d f=12(P=0.003) ; I^{2}=60 \% \\
\text { Test for overall effect: } Z=2.09(P=0.04)\end{array}$} \\
\hline \multicolumn{6}{|l|}{ 1.7.8 Rituximab } \\
\hline Emery 2006 & 3 & 124 & 0 & 149 & $0.4 \%$ \\
\hline Haus: & 3 & 69 & 2 & 35 & $0.8 \%$ \\
\hline Subtotal $(95 \% \mathrm{Cl})$ & & 193 & & 184 & $1.2 \%$ \\
\hline Total events & 6 & & 2 & & \\
\hline \multirow{2}{*}{\multicolumn{6}{|c|}{$\begin{array}{l}\text { Heterogeneity: } \text { Tau }^{2}=1.56 ; \mathrm{Ch}^{2}=1.98, \text { df }=1(P=0.16) ; \mathrm{P}^{2}=50 \% \\
\text { Test for overall effect: } Z=0.54(P=0.59)\end{array}$}} \\
\hline & & & & & \\
\hline \multicolumn{6}{|l|}{ 1.7.9 Tocilizumab } \\
\hline Emery 2008b & 10 & 163 & 8 & 160 & $2.1 \%$ \\
\hline Maini 2006 & 5 & 54 & 4 & 49 & $1.3 \%$ \\
\hline Smolen 2008 & 7 & 212 & 2 & 204 & $1.1 \%$ \\
\hline Subtotal $(95 \% \mathrm{Cl})$ & & 429 & & 413 & $4.5 \%$ \\
\hline Total events & 22 & & 14 & & \\
\hline \multirow{2}{*}{\multicolumn{6}{|c|}{$\begin{array}{l}\text { Heterogeneity: } \text { Tau }^{2}=0.00 ; \mathrm{Chi}^{2}=1.37 \text {, df }=2(P=0.51) ; \mathrm{P}^{2}=0 \% \\
\text { Test for overall effect: } Z=1.11(P=0.27)\end{array}$}} \\
\hline & & & & & \\
\hline Total $(95 \%$ Cl) & & 12548 & & 10088 & $100.0 \%$ \\
\hline Total events & 797 & & 523 & & \\
\hline \multirow{2}{*}{\multicolumn{6}{|c|}{$\begin{array}{l}\text { Heterogeneity: } \text { Tau }^{2}=0.18 ; \mathrm{Chi}^{2}=113.21, \mathrm{df}=73(\mathrm{P}=0.002) ; \mathrm{P}^{\mathrm{P}}=36 \% \\
\text { Test for overall effect: } \mathrm{Z}=2.14(\mathrm{P}=0.03)\end{array}$}} \\
\hline & & & & & \\
\hline Test for subaroup differe & & & & & \\
\hline
\end{tabular}

Heterogeneitr. $\operatorname{Tau}^{2}=0.69 ; \mathrm{Chi}^{2}=29.96$, df $=12(\mathrm{P}=0.003) ; \mathrm{P}^{2}=60 \%$

$8.61[0.44,168.37]$ $0.75[0.12,4.71]$ $1.93[0.18,21.22]$

$0.81[0.21,3.16)$

$4.65[1.77,12.24]$

$6.63[0.30,145.31]$

$5.55[0.68,45.05]$

$3.22[1.52,6.83]$

$30.27[1.40,654.02]$

$0.70[0.30,1.64]$

$0.44[0.19,1.02]$

$1.33[0.39,4.60]$

$1.99[1.04,3.80]$

$1.24[0.48,3.23]$

$1.15[0.29,4.54]$

$3.45[0.71,16.80]$

$1.49[0.74,3.01]$

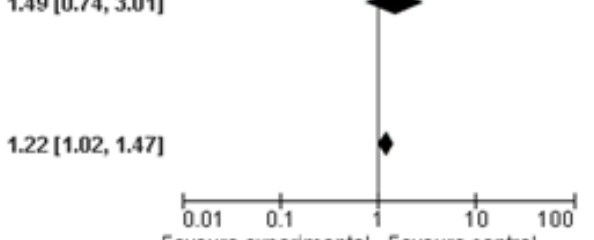

Favours experimental Favours control

\section{6d. Serious infections}

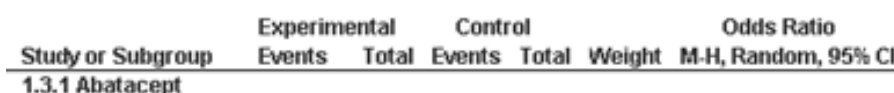

Odds Ratio

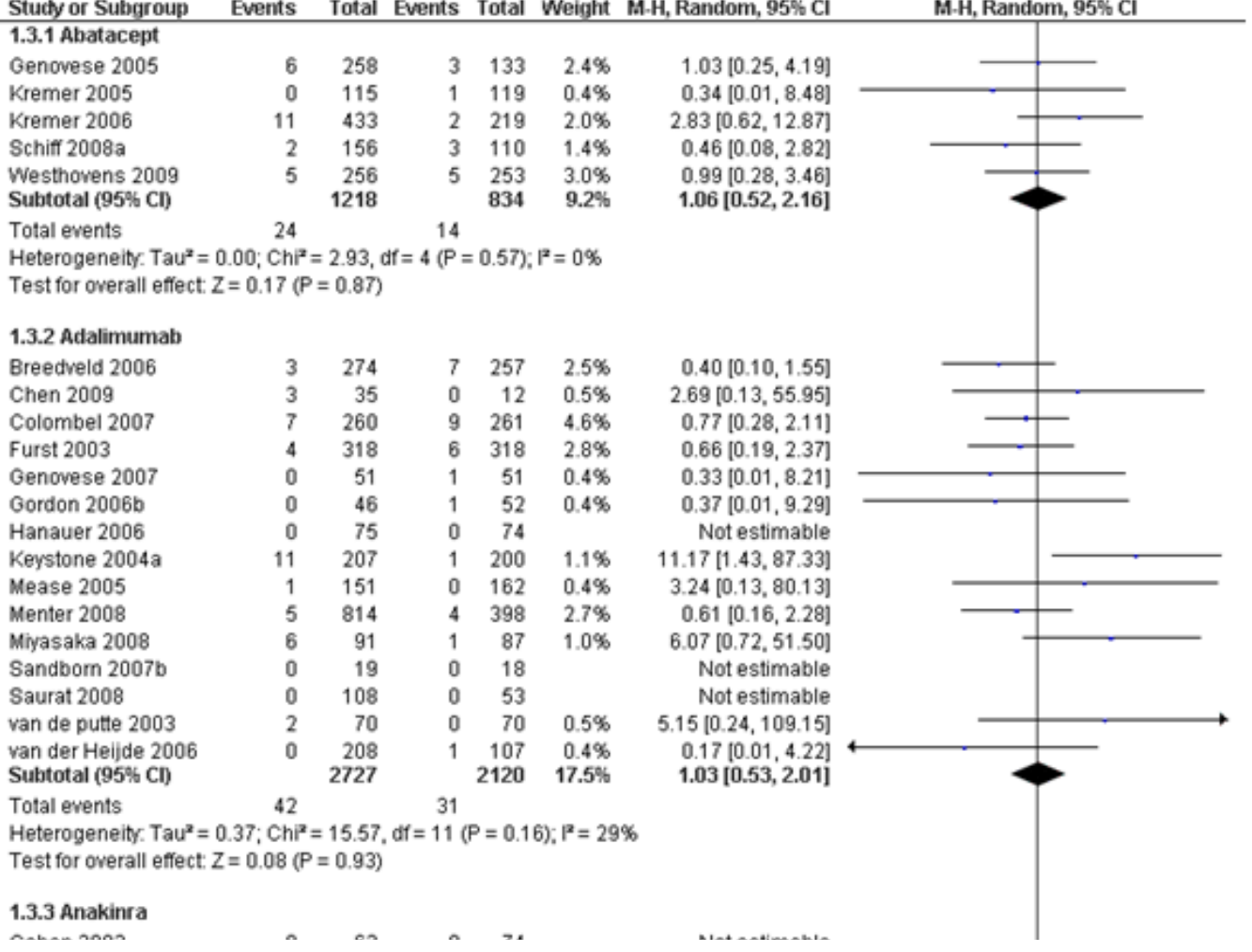


Figure 6. (Continued)

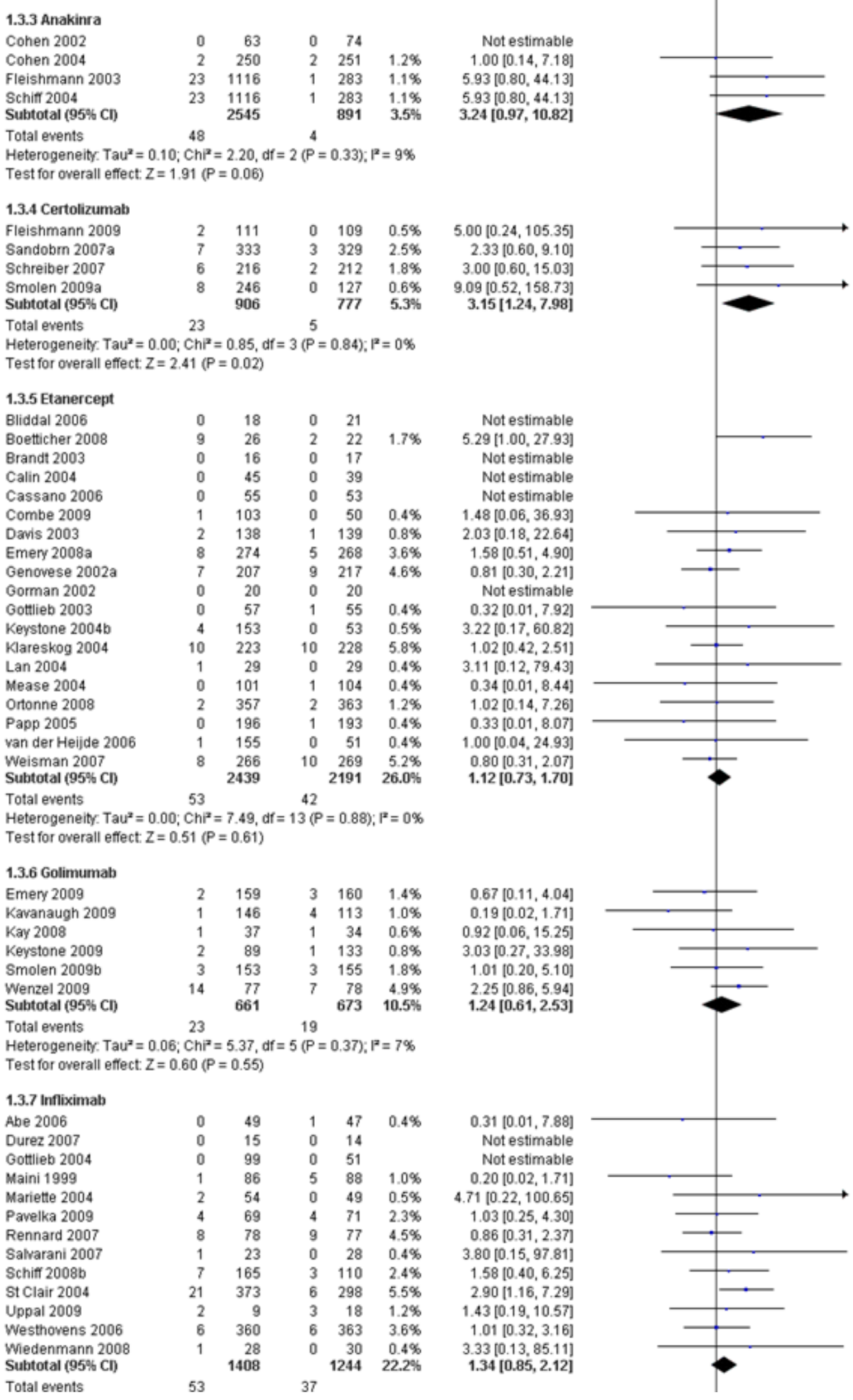


Figure 6. (Continued)

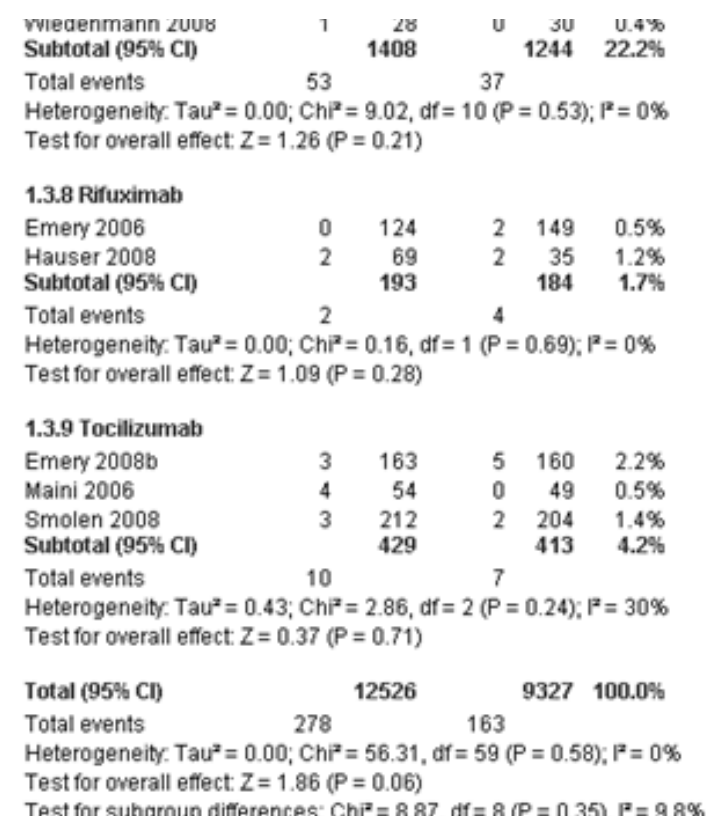

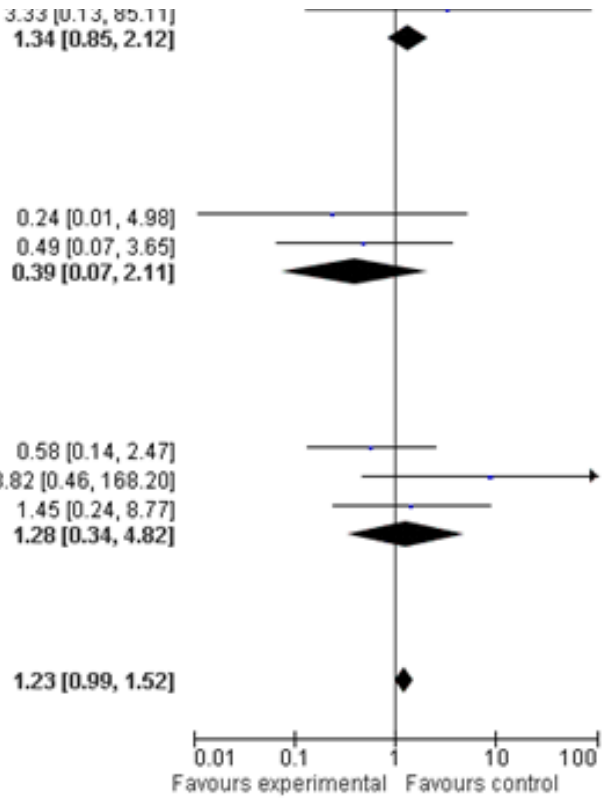

\section{Individual safety of the nine biologics compared to control treatment}

The statistical models for the network meta-analysis did not converge when modeling each of the biologics, in particular for TB reactivation, congestive heart failure, and lymphoma. This was due to a low number of events. Thus for these estimates we were unable to provide estimates for each individual biologic. Details on the overall incidence estimates are provided in Table 5.

Serious adverse events (Table 7; Figure 5):comparing individual biologics to control, only one biologic was statistically significantly different from control in terms of the number of SAEs. Certolizumab pegol was associated with a higher odds of SAEs (OR 1.57, 95\% CI 1.06 to 2.32). In sensitivity analyses, the OR for certolizumab pegol was statistically significant in the unadjusted model (OR 1.66, 95\% $\mathrm{Cl} 1.08$ to 2.59 ), but not statistically significant in the model that was adjusted for dose (OR 1.57; 95\% $\mathrm{Cl} 0.96$ to 2.57) (Appendix 4).

Total adverse events (Table 8; Figure 2): as illustrated in the forest plot, infliximab was associated with statistically significantly higher odds of total AEs compared with control treatment (OR 1.55, 95\% Cl 1.01 to 2.35). None of other biologics were statistically significantly different from control groups regarding total $\mathrm{AEs}$, with odds ratios ranging from 1.03 to 1.54 . In sensitivity analyses, infliximab was associated with significantly higher odds of total AEs compared with control in the unadjusted model (OR $1.54,95 \% \mathrm{Cl} 1.17$ to 2.03 ); differences showed a trend, but were not significant in the doseadjusted model (OR 1.45, 95\% Cl 0.98 to 2.11) (Appendix 5).

Withdrawals due to adverse events (Table 9; Figure 3): infliximab was associated with a statistically significantly increased odds of withdrawal due to AES compared with control (OR 2.34, 95\% Cl 1.40 to 4.14 ). None of other biologics were statistically significantly different from control groups regarding withdrawals due to adverse events, with odds ratios ranging from 1.17 to 2.74 . In sensitivity analyses, infliximab was associated with statistically significantly higher odds of withdrawal due to adverse events compared to control in both the unadjusted (OR $2.32,95 \% \mathrm{Cl} 1.63$ to 3.37 ) and the dose-adjusted model (OR 2.29, $95 \% \mathrm{Cl} 1.45$ to 3.73) (Appendix 6).

Serious infections (Table 10; Figure 4): in comparing the individual biologics to control, two biologics had statistically significantly higher odds of association with serious infections compared with control treatment - certolizumab pegol (OR 4.75, 95\% Cl 1.52 to 18.45 ) and anakinra (OR, $4.05,95 \% \mathrm{Cl} 1.22$ to 16.84 ). Although none of the results for the other biologics reached statistical significance, rituximab was associated with the lowest numerical odds for serious infections compared with control treatment (OR 0.26, 95\% $\mathrm{Cl} 0.03$ to 2.16). In sensitivity analyses, the ORs for certolizumab pegol and anakinra were statistically significant in the unadjusted models (OR 4.65, 95\% Cl 1.61 to 16.22; and OR 3.96, 95\% Cl 1.27 to 15.75 , respectively), as well as the dose-adjusted models (OR 4.67, $95 \% \mathrm{Cl} 1.58$ to 16.15 ; and OR $4.03,95 \% \mathrm{Cl} 1.29$ to 16.22 , respectively) (Appendix 7). As an example of robustness of our findings using several other statistical approaches (five more approaches) and performing sensitivity analyses, we found that OR for certolizumab pegol ranged between 4.12 and 4.81 , a statistically significant result in each instance (Appendix 8).

\section{Safety of individual biologics compared to each other: indirect comparisons}

In order to examine the comparative effectiveness of one biologic against another, as pre-specified in the protocol, we also considered pairwise indirect comparisons across the network in cases where the statistical model converged (that is, where the model allowed us to output inferential statistics). The models 
did not converge for congestive heart failure, lymphoma, and TB reactivation outcomes. The primary analyses for these models was the standard dose model, for which results were presented in detail as below; sensitivity analyses were performed using the unadjusted model and dose-adjusted model (presented in the tables, but not discussed in detail).

Serious adverse events (Table 11): Certolizumab pegol was statistically significantly more likely to be associated with SAEs compared to adalimumab (OR $1.63,95 \% \mathrm{CI} 1.01$ to 2.62). Abatacept was statistically significantly less likely to be associated with SAEs compared to certolizumab (OR $0.56,95 \% \mathrm{Cl} 0.33$ to 0.94 ). In sensitivity analyses in unadjusted model, neither differences were significant. Golimumab was statistically significantly less likely to be associated with SAEs compared to adalimumab (OR $1.18,95 \% \mathrm{Cl} 1.10$ to 3.14) (Appendix 9). There were no other statistically significant differences between the biologics in both the unadjusted model and dose-adjusted model (Appendix 9).

Total adverse events (Table 12): There were no statistically significant differences between any biologics for total AEs in indirect comparisons with each other in any of the models (Appendix 10).

Withdrawals due to adverse events (Table 13): There were no statistically significant differences between any biologics for withdrawals due to adverse events in indirect comparisons with each other. In sensitivity analyses in unadjusted model, infliximab was more likely to be associated with withdrawals due to AEs compared with abatacept (OR $1.92,95 \% \mathrm{Cl} 1.01$ to 3.71), adalimumab (OR $2.00,95 \% \mathrm{Cl} 1.17$ to 3.49 ), and etanercept (OR 1.72 , $95 \% \mathrm{Cl} 1.02$ to 2.91 ). Rituximab was also more likely to be associated with withdrawals due to $\mathrm{AEs}$ than adalimumab (OR 2.17, 95\% $\mathrm{Cl} 1.04$ to 4.74) (Appendix 11).

Serious infections (Table 14): Certolizumab pegol was associated with higher odds of serious infections than abatacept, adalimumab, etanercept, golimumab and rituximab. The odds ratio were roughly 0.25 -times or lower for each of the five biologic compared with certolizumab, in the indirect comparisons (Table 14). These differences persisted in sensitivity analyses in the unadjusted model and dose-adjusted models for each of the five biologics versus certolizumab, with one minor exception of certolizumab versus golimumab, where the confidence interval crossed one (OR $0.28,95 \% \mathrm{Cl} 0.07$ to 1.01 ) in unadjusted dose model (Appendix 12). Anakinra was associated with a statistically significantly higher odds of serious infections compared with rituximab (Table 14).

\section{A priori specified stratified meta-analyses}

These analyses were performed using the frequentist network meta-analyses. The results of the six pre-specified subgroup analyses (by individual biologic; TNF inhibitor or not; TNF antibody or TNF receptor inhibitor or other class; trial duration (short, intermediate or long duration); concomitant medication (MTX + other DMARD, MTX, other DMARD, none); and disease condition (ankylosing spondylitis, cancer, IBD, psoriasis, psoriatic arthritis, RA, other conditions) are shown in Table 15 [Note: these analyses were not adjusted for drug dose]. Only significant differences are noted in the text below.

Serious adverse events (Table 15): There were no statistically significant differences by individual biologic $(P=0.3126)$. No statistically significant differences were noted according to whether the biologic was a TNF inhibitor or not, a TNF antibody or TNF receptor inhibitor or other class of biologic. Statistically significant differences were noted with lower odds of SAEs with trial duration longer than 12 months $(P<0.0001)$. We also noted no statistically significant differences by the type of concomitant medication. When stratified by disease condition, no disease condition was associated with a statistically significant higher risk of SAEs. Overall, there was no statistically significant effect of biologics as a group compared with control groups.

Total adverse events (Table 15): Statistically significant differences were noted for each subgroup comparison. There were statistically significant differences by each biologic $(P=0.0216)$, with etanercept and infliximab being statistically significantly different than control. We also noted statistically significant differences based on whether the biologic was TNF inhibitor or not $(P=0.0021)$, the biologic was a TNF antibody or TNF receptor inhibitor or other class of biologic $(P=0.0097)$, trial duration $(P<0.001)$, concomitant medication $P=0.0723$ ) and by disease condition $(P=0.0166)$. When stratified by disease condition, patients with ankylosing spondylitis and psoriasis had a statistically significant higher risk of serious adverse events, while those with other conditions had nonsignificant differences. Overall, there was a statistically significant effect of biologics as a group compared to control groups $(P=$ 0.0006).

Withdrawals due to adverse effects (Table 15): Significant differences were noted in all six subgroup comparisons. Significant differences were noted by biologic $(P=0.0006)$, since infliximab was associated with significantly higher odds, while other biologics were not. While both TNF inhibitors and non-TNF inhibitors were associated with significantly higher odds, they differed from each other significantly $(P<0.0001)$. Significant differences were also noted according to whether the biologic was a TNF antibody or TNF receptor inhibitor or other class of biologic $(P<0.0001)$, trial duration $(P<0.0001)$, the type of concomitant medication $(P=$ $0.0004)$ and by the disease condition $(P<0.001)$. When stratified by concomitant medication, patients receiving other non-MTX DMARDs as concomitant medications had a statistically significant higher risk of withdrawals due to adverse events, while the MTX group and those that received no concomitant medications had no significant differences compared with the control group. Overall, there was a statistically significant effect of biologics as a group compared to control groups $(\mathrm{P}<0.0001)$.

Serious infections (Table 15): Statistically significant differences were noted in all six subgroup comparisons. Statistically significant differences were noted by individual biologic $(P=0.0003)$ since certolizumab pegol and infliximab were associated with significantly higher odds, while other biologics were not. While both TNF inhibitors and non-TNF inhibitors were associated with statistically significantly higher odds, they differed from each other statistically significantly $(P=0.0002)$. Statistically significant differences were also noted according to whether the biologic was a TNF antibody or TNF receptor inhibitor or other class of biologic $(P=0.0004)$, trial duration $(P<0.0001)$, the type of concomitant medication $(P=0.0176)$ and by the disease condition $(P=0.0001)$. In particular, biologics in patients with RAwere associated with statistically significantly higher risk of serious infections compared with controls, whereas odds in other disease conditions did not differ statistically significantly from controls. Overall, there was a 
statistically significant effect of biologics as a group compared with control groups $(P=0.0003)$.

Sensitivity analyses: Only four RCTs were judged to be at high risk of bias of allocation concealment while the majority (61\%) were marked as unclear given the lack of details on concealment of allocation in the trial reports. Although we did not undertake a stratified analyses by risk of bias of allocation concealment, we expect that the effect estimate would not change dramatically by only taking out the four studies at high risk of allocation concealment bias. In those trials that were pivotal studies used for FDA or European Agency approval, allocation concealment was required in their protocols so although it is troubling that the details were not recorded in the trial report publications this may not be a major bias.

We did not have enough data for the models to run with the stratified analysis for congestive heart failure, lymphoma, and TB reactivation outcomes. The model could not run for a stratified analysis by trial duration for SAEs and by disease for serious infections, respectively.

Heterogeneity: Inconsistency of the results of the network metaanalysis was assessed, as described in the methods section. We found no evidence of inconsistency for all of the outcomes with the exception of 'withdrawals due to adverse events', and the source of heterogeneity could not be clearly identified.

\section{'Optimal Information Size' (OIS)}

\section{Serious adverse events: certolizumab pegol versus control}

In calculating the OIS, we used empirical data from Table 4. For a comparison of two independent binomial proportions using Pearson's $\mathrm{Chi}^{2}$ statistic with a $\mathrm{Chi}^{2}$ approximation with a two-sided significance level of 0.05 , a sample size 1,246 patients in total achieves a power of at least 0.8 when the proportions are 0.174 and 0.118 . Thus, the calculated OIS was substantially lower than the total sample size included (1,246 versus 2,421 patients). As this meta-analysis, meets the OIS criteria, there is no reason to rate down for imprecision.

\section{Serious infections: certolizumab pegol versus control}

In calculating the OIS, we used empirical data from Table 4. For a comparison of two independent binomial proportions using Pearson's $\mathrm{Chi}^{2}$ statistic with a $\mathrm{Chi}^{2}$ approximation with a two-sided significance level of 0.05 , a sample size of 266 patients in total achieves a power of at least 0.8 when the proportions are 0.113 and 0.026 . Thus, the calculated OIS was substantially lower than the total sample size included (266 versus 1,683 patients). As this metaanalysis, meets the OIS criteria, there is no reason to rate down for imprecision.

\section{Withdrawals due to adverse events: infliximab versus control}

In calculating the OIS, we used empirical data from Table 4. For a comparison of two independent binomial proportions using Pearson's $\mathrm{Chi}^{2}$ statistic with a $\mathrm{Chi}^{2}$ approximation with a two-sided significance level of 0.05 , a sample size of 362 patients in total achieves a power of at least 0.8 when the proportions are 0.203 and 0.098 . Thus, the calculated OIS was substantially lower than the total sample size included ( 362 versus 2,973 patients). As this metaanalysis, meets the OIS criteria, there is no reason to rate down for imprecision.

\section{Results from extension studies of randomized trials}

We analyzed the open-label extensions (OLEs) of randomized trials. Data from 59 study arms were available. These included 11,954 patients with 325,904 person-months of observation (Table 16). Serious adverse events were reported in $9 \%$ to $54 \%$ of patients receiving biologics. Serious infections were noted in $1 \%$ to $18 \%$. TB reactivation was reported in $0 \%$ to $0.6 \%$. Lymphoproliferative cancer was reported in $0 \%$ to $0.4 \%$, and congestive heart failure in $0.1 \%$ to $0.7 \%$ of patients.

\section{DISCUSSION}

\section{Summary of main results}

This review of the safety of nine biologics commonly used to treat rheumatoid arthritis (RA) and other conditions included 160 randomized controlled trials with 48,676 participants that investigated the efficacy and safety of these drugs across a variety of conditions including RA. The majority of studies were of fairly short duration, with the median RCT duration being six months (range, one to 63 months), so the results should be considered with this time frame in mind. We combined data across diseases according to the premise that the adverse event profile of biologics would be similar irrespective of the condition being treated. We found that compared with control treatments, biologics were associated with statistically significantly higher rates of total adverse events, withdrawals due to adverse events, serious infections and tuberculosis (TB) reactivation. In most studies, serious infections included opportunistic infections in addition to bacterial and other infections. Specifically, infliximab was associated with a statistically significantly higher rate of total adverse events and withdrawals due to adverse events compared with control treatment. Certolizumab pegol and anakinra were associated with a statistically significantly higher risk of serious infections compared with control treatment. Certolizumab pegol was associated with a significantly higher risk of serious adverse events compared with control treatment. Since models did not converge for TB reactivation, lymphoma and congestive heart failure, comparative risk estimates of each biologic compared with control could not be calculated.

The open-label data provided estimates on rare adverse events related to biologics, such as serious infections and TB reactivation. The open-label data provides important safety data by providing a longer duration of follow-up and larger sample size in many cases thus complimenting data from clinical registries. The latter have been extremely helpful in providing safety data. The open-label extension studies included in this review ranged from three to 60 months duration, with the median being 13 months. However, this time frame may still be too short to address serious but rare adverse events and long-term adverse events such as cancer. The estimates from the open-label phases of clinical trials may be lower than those noted from registry studies since the populations recruited in clinical trials tend to be healthier than the general population due to strict inclusion criteria. Patients recruited in trials of each biologic may differ from each other, which may partially explain the differences in rates of certain adverse events.

Indirect comparisons revealed that the biologics differed from each other with respect to the odds of serious infections and serious adverse events. Certolizumab pegol was associated 
with statistically significantly higher odds of serious infections compared with abatacept, adalimumab, etanercept, golimumab and rituximab. Anakinra was associated with statistically significantly higher odds of serious infections compared with rituximab. Certolizumab pegol was associated with statistically significantly higher odds of serious adverse events compared with abatacept and adalimumab. No significant differences were noted for adverse events or withdrawals due to adverse events between biologics in indirect comparisons.

Stratified meta-analyses based on a priori subgroups revealed interesting findings. Compared with control, serious infections, total adverse events, and withdrawals due to adverse events differed statistically significantly by the individual biologic. Compared with control, TNF inhibitors and non-TNF biologics differed statistically significantly with respect to serious infections and total adverse events with odds numerically slightly higher for TNF inhibitors, and in withdrawals due to adverse events with odds slightly higher for non-TNF biologics. In shorter trials (< six months), biologics were associated with statistically significantly higher odds of serious infections, total adverse events and withdrawals due to adverse events compared with controls. Data were insufficient for congestive heart failure, lymphoma, and TB reactivation. Type of concomitant medication was associated with statistically significant differences for serious infections, total adverse events and withdrawals due to adverse events. When stratified by disease, we found that there were some differences in the risk of these outcomes across different diseases, with the most consistent finding being that ankylosing spondylitis and psoriasis were associated with a higher risk of total adverse events, and RA with a higher risk of serious infections. It is not clear from our analysis why this may be although in view of the multiple analyses performed this finding should be interpreted with caution. It is unclear how these differences in risk across the different conditions may affect our pre-specified decision to pool data across different conditions.

The US FDA's black box warning regarding increased serious infections with most biologics, except abatacept, needs to be considered when prescribing these biologics. Similar observations have been made by observational and registry studies. The lack of statistically significant differences for individual biologics compared to control and overall biologics compared to control in our analyses likely indicates a lack of power (beta-error) due to small numbers of patients and a short follow-up in the RCTs, as described in the limitations section.

\section{Overall completeness and applicability of evidence}

Our published protocol described our plan to analyze a series of major and minor outcomes. We analyzed all seven major outcomes and all other analyses related to them, as pre-specified. All eligible RCTs and open-label extensions up to March 2010 were included. However, due to the complexity of analyses for the major outcomes and the few studies with low numbers of events reporting this data, we decided not to add to the complexity of this review by analyzing the minor outcomes. This decision was made prior to embarking upon any analyses of minor outcomes to avoid any bias in the decision-making process.

\section{Quality of the evidence}

There were 160 RCTs with 48,676 participants included in this analysis. In the majority of studies generation of the allocation sequence and allocation concealment were judged to be 'unclear' due to lack of details provided in the study reports. Only four RCTs were clearly at a high risk of bias for allocation concealment. Blinding was also not clearly described in many of the included studies; however, only 10 RCTs were clearly at a high risk of bias as they were described as 'open-label'. There was greater than $80 \%$ follow-up in the majority of studies and most were judged to have a low risk of bias due to major baseline imbalances. Although we did not search for study protocols, the majority of included studies were judged to be at a low risk of bias for selective outcome reporting due to the fact that important side effects were often reported. Most included trials reported that adverse events were actively monitored. When assessing and combining serious adverse event data, it is important that a definition is provided for how the trialists defined a serious adverse event (SAE); the majority of trials in this review did not provide sufficient information on how a SAE was defined in the study. We combined data on SAEs regardless of the definition and whether it was provided, so caution is needed in interpreting this outcome.

We assessed whether trials reported undertaking active monitoring for adverse events, as a risk of bias criterion specific to adverse effects. The majority of included RCTs were judged to be at low risk of bias for this item, mainly because published trial reports included a statement to the effect that they monitored for adverse effects. However, it should be noted that this is a difficult criterion to assess as many different monitoring techniques may have been used, with varying reliability of the different approaches. As well, the method of monitoring may need to be specific to the different adverse events of interest and this would not have been captured in our broadly defined criteria.

Although the majority of included studies were judged to be at low risk of bias for selective outcome reporting (54\%), this was based on the judgement of the data extractors that most of the adverse events of interest to this review (as pre-specified in our protocol) were reported adequately. We did not have the resources to find and review the protocols or full clinical trial reports (if either was even available) of the 160 included studies, which would have been the best way to assess this criterion. As well, given the problems as described above with detecting adverse events, it is difficult to discriminate between being sure that an event actually did not happen and whether it happened but was not detected due to the method of monitoring used during the trial, or if it was selectively not reported. The judgement was made across all adverse events included in our review rather than by specific adverse event, so we are unable to determine if there are specific adverse events which may be more susceptible to selective outcome reporting. Another issue is how adverse events are defined and counted in trials. For the most part the adverse events included in this review are fairly straightforward to define clinically, with the exception perhaps of CHF. The lack of reporting and consensus of the definition of SAE were noted as potential sources of bias since $63 \%$ of included studies did not provide a clear definition.

We included 46 extension studies with 11,954 participants. Given the nature of extension studies, in which a highly selected group of participants continue on from the RCT and the majority of participants and outcome assessors are not blinded, most of these 
studies were judged to be at a high risk of bias. As well, more than half of the studies were judged to be at a high risk of attrition bias due to withdrawal rates greater than $20 \%$. The majority of studies either reported expected adverse effects or there was insufficient information to judge whether they were at risk of selective outcome reporting. As with RCTs, serious adverse events were not clearly defined in most studies but the majority reported some type of active monitoring for adverse events.

For the overall results of biologics as a group versus placebo for the major outcomes of serious adverse events, serious infections, total adverse events, and withdrawals due to adverse events, our confidence in the results was graded as 'moderate' using the GRADE approach. Due mainly to lack of data, our confidence in the results for TB reactivation, lymphoma, and congestive heart failure was graded as 'low', implying that further research is likely to have an important impact on the confidence in an estimated effect and may change that estimate.

\section{Potential biases in the overview process}

Our review has limitations. Despite inclusion of a large number of RCTs across conditions, which allowed analyses for four of our pre-specified major outcomes (that is, serious adverse events, serious infections, total adverse events, and withdrawals due to adverse events), for three major outcomes (that is, TB reactivation, lymphoma, and congestive heart failure), events were too few to allow meaningful indirect comparisons or stratified meta-analyses.

In view of the lack of head-to-head studies of biologics, we performed indirect comparisons cognizant of the limitations of this approach. Use of this methodology requires assumptions about the comparability of the included RCTs in terms of similarity of patient characteristics and methodological quality. However, clinicians and patients are faced with the dilemma of choosing from among these biologics in the absence of robust comparative data about their relative safety. While we included trials which differed in patient populations, prior failed therapies, concomitant use of disease modifying anti-rheumatic drug (DMARDs), trial duration, and biologic dose, we attempted to adjust for these differences in the analysis. We performed standard dose models as our main analyses, tested the robustness of results by performing sensitivity analyses with unadjusted dose and dose-adjusted models and performed additional stratified metaanalyses to explore differences in other important characteristics (that is, concomitant DMARDs, trial duration). We also performed standard meta-analysis, which also confirmed the robustness of our findings, with minimal changes in odds ratios and no change in interpretation of main effects of biologics compared with control treatment. We performed additional sensitivity analyses (five additional models) to test the robustness of our findings, with the example of higher serious infections with certolizumab pegol compared with control. We did not find evidence of inconsistency in the majority of the results from our indirect comparison analyses, however, these findings should be interpreted with caution. We may be underpowered for several stratified meta-analyses.

For this review, we limited inclusion to RCTs and their open-label extensions. However long-term observational studies, including population-based registries, can provide realistic longer-term estimates of the risks of biologics in the 'real world', although they too have their limitations. These may include indication bias and differences in healthcare setting, country of origin of study, which may impact the choice of biologic and make generalizability challenging. We intend to undertake a second phase of this project which will include observational studies, to try and address the issue of assessing rare or long-term adverse effects.

The analyses are limited by limitations in trial designs. One example is the use of rescue design in some studies where patients are allowed to switch to active medication if they have not responded in the placebo or control arm. This can impact the estimates, since one arm has a continuous exposure to the biologic, where as in the other arm, the exposure is first to the control treatment and then the biologic.

We performed multiple comparisons and therefore, it is possible that some findings may be due to chance only; however it is far more likely that for several analyses there was a lack of power leading to Type-II error (that is, missing a statistically significant difference due to small sample size). Some of these issues may also explain instances where the point estimates for risk appeared large but did not reach statistical significance.

Another limitation of these analyses is that high drop-out rates in some studies may influence the observable adverse event rate; this may have a differential effect depending on whether the drop out rate is higher in placebo versus intervention arm.

We assessed the risk of leukemia and lymphoma across all trials and all biologics to be consistent with the overall strategy we used to assess safety in this overview. However, we recognize that this may be inappropriate in this case for several reasons. We combined all trials including those that assessed efficacy of rituximab to treat lymphoproliferative disorders. As well, different biologics (e.g. TNF inhibitors versus non TNF inhibitors) and different diseases may be associated with different risk profiles for different malignancies. We plan further analyses to explore these issues.

Finally, while all data were independently extracted by ten pairs of review authors, the level of interrater agreement was found to be high, and the data were checked for errors during the course of writing the manuscript, we acknowledge that, due to the large amount of data that was included in this review and the large number of review authors, there is a possibility of chance errors.

\section{Agreements and disagreements with other studies or reviews}

In our study that included RCTs of nine biologics used in any disease condition (except HIV/AIDS), we found that compared with control, only infliximab was associated with a significantly higher risk of withdrawals due to adverse events, with no statistically significant differences between other biologics and control; indirect comparisons did not reveal any differences between infliximab and other biologics in the main standard-dose adjusted analysis. Our findings agree with and extend the findings of a previous review that examined 13 randomized controlled trials of at least six months duration of etanercept, infliximab, and adalimumab for RA (Alonso-Ruiz 2008). They also reported that infliximab and adalimumab had higher than control withdrawal rates due to adverse events; similarly in this study we found that infliximab was associated with higher odds of withdrawals due to adverse events compared with control treatment. However, indirect comparisons found no significant differences between biologics in withdrawals due to adverse events. In our previous 
Cochrane review of RCTs, including only trials of approved doses of six biologics for treatment of RA, we found that adalimumab, anakinra, and infliximab were more likely than etanercept to lead to withdrawals due to adverse events (Singh 2009a; Singh 2009b). Lee et al reported no differences for withdrawals due to adverse events (Lee 2008), however only three studies were included, which was likely to lead to type-II error. The indirect comparisons presented in our study add to the current literature.

In two meta-analyses of nine (Bongartz 2006) and 13 RCTs (AlonsoRuiz 2008) of TNF biologics, which included some of the same RCTs, infliximab was associated with twice the risk of serious adverse events and infections as the control (Alonso-Ruiz 2008). Pooled odds ratios for infliximab and adalimumab were significantly higher for serious infections (Bongartz 2006) with odds ratios ranging from 1.2 to 2.0. In contrast, Wiens et al performed a meta-analysis of 21 RCTs of standard (or their equivalent) doses of adalimumab (40 mg every two weeks), etanercept ( $25 \mathrm{mg}$ every two weeks), and infliximab $(3 \mathrm{mg} / \mathrm{kg})$ in RA and reported no differences between each drug and the control for serious infections or serious adverse events (Wiens 2010). The RCTs included in Wiens et al were not identical to the studies included in the other two meta-analyses mentioned above. We noted that compared with control, the odds ratio of serious infections for infliximab was 1.41 , similar to previous studies, but this was not statistically significantly different from control in our analyses.

We found that certolizumab pegol was associated with a statistically significantly higher risk of serious infections compared with control. However, there was often a zero event rate in the control group of the certolizumab pegol studies. Indirect comparisons (that used a control event rate across all studies) showed that certolizumab pegol was associated with significantly higher odds of serious infections compared with abatacept, adalimumab, etanercept, golimumab and rituximab.

Certolizumab pegol was associated with statistically significantly higher odds of serious adverse events compared with control. In indirect comparisons, certolizumab was more likely than abatacept and adalimumab to be associated with serious adverse events.

Most of our findings from indirect comparisons cannot be compared to previous studies since most previous meta-analyses, other than those described above, have focused on efficacy outcomes, and have been limited to a fewer studies, restricted to a particular disease (most commonly, only RA) and were limited to select biologics (i.e., did not include all nine available biologics). These findings should be interpreted with caution in light of the limitations we have described.

\section{AUTHORS' CONCLUSIONS}

\section{Implications for practice}

Several meta-analyses have been published that assessed efficacy of biologics but few have assessed safety. Our review included indirect comparisons of the safety of biologics and should provide some guidance to clinicians and patients until head-to-head comparisons become available.

Our study has several salient findings. Our findings should be interpreted with caution, given study limitations. In short-term RCTs (median duration six months) the overall use of biologics was associated with a statistically significantly higher risk of total adverse events, withdrawals due to adverse events, serious infections and tuberculosis reactivation compared with control.

Specifically, in direct comparisons to control, infliximab was associated with statistically significantly higher numbers of total adverse events, and withdrawals due to adverse events compared with control. Certolizumab pegol was associated with a statistically significantly higher risk of serious infections and serious adverse events compared with control treatment. Since models did not converge for congestive heart failure, lymphoma and TB reactivation, estimates of each biologic compared to control could not be calculated.

Indirect comparisons revealed that although the overall numbers are relatively small, certolizumab pegol was associated with a statistically significantly higher odds of serious infections compared with abatacept, adalimumab, etanercept, golimumab and rituximab; rituximab was statistically significantly less likely than anakinra to be associated with serious infections. No differences were noted between biologics in indirect comparisons for total adverse events and withdrawals due to adverse events.

\section{Implications for research}

Our network meta-analysis provides estimates regarding the overall comparative safety of the biologics. We believe that there is an urgent need for more research regarding the long-term safety of biologics and comparative safety of different biologics. As the number of biologics that are available for treatment of these conditions increases, more options will become available to patients and clinicians. This progress in RA therapeutics provides more options for patients and physicians but offers even more challenges in choosing the best treatment for a given patient. In the absence of comparative effectiveness trials, national and international registries and other types of large databases are the relevant sources for providing complementary evidence regarding the short- and longer-term safety of biologics.

\section{ACKNOWLEDGEMENTS}

We thank Louise Falzon for developing the search strategies and assisting with full text article retrieval. We thank Michelle Fiander and Carolyn Wayne for assisting with full text article retrieval. We thank Michelle Foote, Bharbhoor Dhaliwal and Joseph Kundukulam for assisting with data extraction. 


\section{REFERE N C E S}

\section{References to included reviews}

\section{Abe 2006}

Abe T, Takeuchi T, Miyasaka N, Hashimoto $\mathrm{H}$, Kondo $\mathrm{H}$, Ichikawa Y, et al. A multicenter, double-blind, randomized, placebo controlled trial of infliximab combined with low dose methotrexate in Japanese patients with rheumatoid arthritis. Journal of Rheumatology 2006;33:37-44.

\section{Antoni 2005a}

Antoni C, Krueger GG, De Vlam K, Birbara C, Beutler A, Guzzo C, et al. Infliximab improves signs and symptoms of psoriatic arthritis: results of the IMPACT 2 trial. Annals of the Rheumatic Diseases 2005;64:1150-7.

\section{Antoni 2005b}

Antoni CE, Kavanaugh A, Kirkham B, Tutuncu Z, Burmester GR, Schneider $U$, et al. Sustained benefits of infliximab therapy for dermatologic and articular manifestations of psoriatic arthritis: results from the infliximab multinational psoriatic arthritis controlled trial (IMPACT).[Erratum appears in Arthritis Rheum. 2005 Sep;52(9):2951]. Arthritis and Rheumatism 2005;52:1227-36.

\section{Antoni 2008}

Antoni CE, Kavanaugh A, Van der Heijde D, Beutler A, Keenan G, Zhou B, et al. Two-year efficacy and safety of infliximab treatment in patients with active psoriatic arthritis: findings of the Infliximab Multinational Psoriatic Arthritis Controlled Trial (IMPACT). Journal of Rheumatology 2008;35:869-76.

\section{Aviles 2007a}

Aviles A, Nambo MJ, Castaneda C, Cleto S, Neri N, Murillo E, et al. Rituximab and escalated chemotherapy in elderly patients with aggressive diffuse large-cell lymphoma: a controlled clinical trial. Cancer Biotherapy and Radiopharmaceuticals 2007;22(2):194-9.

\section{Aviles 2007b}

Aviles A, Nambo MJ, Neri N, Cleto S, Castaneda C, HuertaGuzman J, et al. Dose dense (CEOP-14) vs dose dense and rituximab (CEOP-14 +R) in high-risk diffuse large cell lymphoma. Medical Oncology 2007;24:85-9.

\section{Barkham 2009}

Barkham N, Keen HI, Coates LC, O'Connor P, Hensor E, Fraser $A D$, et al. Clinical and imaging efficacy of infliximab in HLA-B27-Positive patients with magnetic resonance imagingdetermined early sacroiliitis. Arthritis and Rheumatism 2009;60:946-54.

\section{Bathon 2000}

Bathon JM, Martin RW, Fleischmann RM, Tesser JR, Schiff MH, Keystone EC, et al. A comparison of etanercept and methotrexate in patients with early rheumatoid arthritis. New England Journal of Medicine 2000;343(22):1586-93.

\section{Bliddal 2006}

Bliddal H, Terslev L, Qvistgaard E, Konig M, Holm CC, Rogind H, et al. A randomized, controlled study of a single intra-articular injection of etanercept or glucocorticosteroids in patients with rheumatoid arthritis. Scandinavian Journal of Rheumatology 2006;35:341-5

\section{Boetticher 2008}

Boetticher NC, Peine CJ, Kwo P, Abrams GA, Patel T, Aqel B, et al. $A$ randomized, double-blinded, placebo-controlled multicenter trial of etanercept in the treatment of alcoholic hepatitis. Gastroenterology 2008;135:1953-60.

\section{Bozkurt 2001}

Bozkurt B, Torre-Amione G, Warren MS, Whitmore J, Soran OZ, Feldman AM, et al. Results of targeted anti-tumor necrosis factor therapy with etanercept (Enbrel) in patients with advanced heart failure. Circulation 2001;103(8):1044-7.

\section{Brandt 2003}

Brandt J, Khariouzov A, Listing J, Haibel H, Sörensen H, Grassnickel L, et al. Six-month results of a double-blind, placebo-controlled trial of etanercept treatment in patients with active ankylosing spondylitis. Arthritis and Rheumatism 2003;48(6):1667-75.

\section{Brandt 2005}

Brandt J, Listing J, Haibel H, Sörensen H, Schwebig A, Rudwaleit M, et al. Long-term efficacy and safety of etanercept after readministration in patients with active ankylosing spondylitis. [Erratum appears in Rheumatology (Oxford). 2005 Apr;44(4):569]. Rheumatology 2005;44:342-8.

\section{Braun 2002}

Braun J, Brandt J, Listing J, Zink A, Alten R, Golder W, et al. Treatment of active ankylosing spondylitis with infliximab: a randomised controlled multicentre trial. Lancet 2002;359(9313):1187-93.

\section{Braun 2003}

Braun J, Brandt J, Listing J, Zink A, Alten R, Burmester G, et al. Long-term efficacy and safety of infliximab in the treatment of ankylosing spondylitis: an open, observational, extension study of a three-month, randomized, placebo-controlled trial. Arthritis and Rheumatism 2003;48(8):2224-33.

\section{Braun 2005}

Braun J, Brandt J, Listing J, Zink A, Alten R, Burmester G, et al. Two year maintenance of efficacy and safety of infliximab in the treatment of ankylosing spondylitis. Annals of the Rheumatic Diseases 2005;64:229-34.

\section{Braun 2008a}

Braun J, Deodhar A, Dijkmans B, Geusens P, Sieper J, Williamson $P$, et al. Efficacy and safety of infliximab in patients with ankylosing spondylitis over a two-year period. Arthritis and Rheumatism 2008;59:1270-8. 


\section{Braun 2008b}

Braun J, Baraliakos X, Listing J, Fritz C, Alten R, Burmester G, et al. Persistent clinical efficacy and safety of anti-tumour necrosis factor alpha therapy with infliximab in patients with ankylosing spondylitis over 5 years: evidence for different types of response. Annals of the Rheumatic Diseases 2008;67:340-5.

\section{Breedveld 2006}

Breedveld FC, Weisman MH, Kavanaugh AF, Cohen SB, Pavelka K, Van Vollenhoven R, et al. The PREMIER study: A multicenter, randomized, double-blind clinical trial of combination therapy with adalimumab plus methotrexate versus methotrexate alone or adalimumab alone in patients with early, aggressive rheumatoid arthritis who had not had previous methotrexate treatment. Arthritis and Rheumatism 2006;54:26-37.

\section{Buske 2009}

Buske C, Hoster E, Dreyling M, Eimermacher $\mathrm{H}$, Wandt $\mathrm{H}$, Metzner $\mathrm{B}$, et al. The addition of rituximab to front-line therapy with $\mathrm{CHOP}$ (R-CHOP) results in a higher response rate and longer time to treatment failure in patients with lymphoplasmacytic lymphoma: results of a randomized trial of the German Low-Grade Lymphoma Study Group (GLSG). Leukemia 2009;23:153-61.

\section{Calin 2004}

Calin A, Dijkmans BA, Emery P, Hakala M, Kalden J, LeirisaloRepo M, et al. Outcomes of a multicentre randomised clinical trial of etanercept to treat ankylosing spondylitis. Annals of the Rheumatic Diseases 2004;63(12):1594-600.

\section{Cassano 2006}

Cassano N, Loconsole F, Galluccio A, Miracapillo A, Pezza M, Vena GA. Once-weekly administration of high-dosage Etanercept in patients with plaque psoriasis: results of a pilot experience (power study). International Journal of Immunopathology and Pharmacology 2006;19:225-9.

\section{Chaudhari 2001}

Chaudhari U, Romano P, Mulcahy LD, Dooley LT, Baker DG, Gottlieb AB. Efficacy and safety of infliximab monotherapy for plaque-type psoriasis: a randomised trial. Lancet 2001;357(9271):1842-7.

\section{Chen 2009}

Chen DY, Chou SJ, Hsieh TY, Chen YH, Chen HH, Hsieh CW, et al. Randomized, double-blind, placebo-controlled, comparative study of human anti-TNF antibody adalimumab in combination with methotrexate and methotrexate alone in Taiwanese patients with active rheumatoid arthritis. Journal of the Formosan Medical Association 2009;108:310-9.

\section{Chevalier 2009}

Chevalier X, Goupille P, Beaulieu AD, Burch FX, Bensen WG, Conrozier $\mathrm{T}$, et al. Intraarticular injection of anakinra in osteoarthritis of the knee: a multicenter, randomized, doubleblind, placebo-controlled study. Arthritis and Rheumatism 2009;61:344-52.

\section{Chung 2003}

Chung ES, Packer M, Lo KH, Fasanmade AA, Willerson JT, AntiTNF Therapy Against Congestive Heart Failure Investigators. Randomized, double-blind, placebo-controlled, pilot trial of infliximab, a chimeric monoclonal antibody to tumor necrosis factor-alpha, in patients with moderate-to-severe heart failure: results of the anti-TNF Therapy Against Congestive Heart Failure (ATTACH) trial. Circulation 2003;107(25):3133-40.

\section{Cohen 2002}

Cohen S, Hurd E, Cush J, Schiff M, Weinblatt ME, Moreland LW, et al. Treatment of rheumatoid arthritis with anakinra, a recombinant human interleukin-1 receptor antagonist, in combination with methotrexate: results of a twenty-four-week, multicenter, randomized, double-blind, placebo-controlled trial. Arthritis and Rheumatism 2002;46(3):614-24.

\section{Cohen 2004}

Cohen SB, Moreland LW, Cush JJ, Greenwald MW, Block S, Shergy WJ, et al. A multicentre, double blind, randomised, placebo controlled trial of anakinra (Kineret), a recombinant interleukin 1 receptor antagonist, in patients with rheumatoid arthritis treated with background methotrexate. Annals of the Rheumatic Diseases 2004;63(9):1062-8.

\section{Cohen 2005}

Cohen S, Shoup A, Weisman MH, Harris J. Etanercept treatment for autoimmune inner ear disease: results of a pilot placebocontrolled study. Otology \& Neurotology 2005;26:903-7.

\section{Cohen 2006}

Cohen SB, Emery P, Greenwald MW, Dougados M, Furie RA, Genovese MC, et al. Rituximab for rheumatoid arthritis refractory to anti-tumor necrosis factor therapy: Results of a multicenter, randomized, double-blind, placebo-controlled, phase III trial evaluating primary efficacy and safety at twentyfour weeks. Arthritis and Rheumatism 2006;54(9):2793-806.

\section{Coiffier 1998}

Coiffier B, Haioun C, Ketterer N, Engert A, Tilly H, Ma D, et al. Rituximab (anti-CD20 monoclonal antibody) for the treatment of patients with relapsing or refractory aggressive lymphoma: a multicenter phase II study. Blood 1998;92(6):1927-32.

\section{Coiffier 2002}

Coiffier B, Lepage E, Briere J, Herbrecht R, Tilly H, Bouabdallah R, et al. CHOP chemotherapy plus rituximab compared with $\mathrm{CHOP}$ alone in elderly patients with diffuse large-B-cell lymphoma. New England Journal of Medicine 2002;346(4):235-42.

\section{Colombel 2007}

Colombel J-F, Sandborn WJ, Rutgeerts P, Enns R, Hanauer SB, Panaccione $\mathrm{R}$, et al. Adalimumab for maintenance of clinical response and remission in patients with Crohn's disease: the CHARM trial. Gastroenterology 2007;132:52-65.

\section{Combe 2009}

Combe B, Codreanu C, Fiocco U, Gaubitz M, Geusens PP, Kvien TK, et al. Efficacy, safety and patient-reported outcomes of combination etanercept and sulfasalazine versus etanercept 
alone in patients with rheumatoid arthritis: a double-blind randomised 2-year study. Annals of the Rheumatic Diseases 2009;68:1146-52.

\section{Copelan 2009}

Copelan E, Pohlman B, Rybicki L, Kalaycio M, Sobecks R, Andresen $S$, et al. A randomized trial of etoposide and GCSF with or without rituximab for PBSC mobilization in Bcell non-Hodgkin's lymphoma. Bone Marrow Transplantation 2009;43:101-5

\section{Davis 2003}

Davis JC, Van Der Heijde D, Braun J, Dougados M, Cush J, Clegg DO, et al. Recombinant human tumor necrosis factor receptor (etanercept) for treating ankylosing spondylitis: a randomized, controlled trial. Arthritis and Rheumatism 2003;48(11):3230-6.

\section{Davis 2004}

Davis J, Webb A, Lund S, Sack K. Results from an open-label extension study of etanercept in ankylosing spondylitis. Arthritis and Rheumatism 2004;51(2):302-4.

\section{Davis 2008}

Davis J C Jr, Van der Heijde D M, Braun J, Dougados M, Clegg D O, Kivitz A J, et al. Efficacy and safety of up to 192 weeks of etanercept therapy in patients with ankylosing spondylitis. Annals of the Rheumatic Diseases 2008;67:346-52.

\section{Den Broeder 2002}

Den Broeder A, Van de Putte L, Rau R, Schattenkirchner M, Van Riel P, Sander O, et al. A single dose, placebo controlled study of the fully human anti-tumor necrosis factor-alpha antibody adalimumab (D2E7) in patients with rheumatoid arthritis. Journal of Rheumatology 2002;29(11):2288-98.

\section{Dijkmans 2009}

Dijkmans B, Emery P, Hakala M, Leirisalo-Repo M, Mola E M, Paolozzi L, et al. Etanercept in the longterm treatment of patients with ankylosing spondylitis. Journal of Rheumatology 2009;36(6):1256-64.

\section{Durez 2007}

Durez P, Malghem J, Nzeusseu Toukap A, Depresseux G, Lauwerys BR, Westhovens R, et al. Treatment of early rheumatoid arthritis: a randomized magnetic resonance imaging study comparing the effects of methotrexate alone, methotrexate in combination with infliximab, and methotrexate in combination with intravenous pulse methylprednisolone. Arthritis and Rheumatism 2007;56:3919-27.

\section{Edwards 2004}

Edwards JC, Szczepanski L, Szechinski J, FilipowiczSosnowska A, Emery P, Close DR, et al. Efficacy of Bcell-targeted therapy with rituximab in patients with rheumatoid arthritis. New England Journal of Medicine 2004;350(25):2572-81.

\section{Emery 2006}

Emery P, Fleischmann R, Filipowicz-Sosnowska A, Schechtman J, Szczepanski L, Kavanaugh A, et al. The efficacy and safety of rituximab in patients with active rheumatoid arthritis despite methotrexate treatment: results of a phase IIB randomized, double-blind, placebo-controlled, dose-ranging trial. Arthritis and Rheumatism 2006;54(5):1390-400.

\section{Emery 2008a}

Emery P, Breedveld FC, Hall S, Durez P, Chang DJ, Robertson D, et al. Comparison of methotrexate monotherapy with a combination of methotrexate and etanercept in active, early, moderate to severe rheumatoid arthritis (COMET): a randomised, double-blind, parallel treatment trial. Lancet 2008;372:375-82.

\section{Emery 2008b}

Emery P, Keystone E, Tony HP, Cantagrel A, Van Vollenhoven R, Sanchez A, et al. IL-6 receptor inhibition with tocilizumab improves treatment outcomes in patients with rheumatoid arthritis refractory to anti-tumour necrosis factor biologicals: results from a 24-week multicentre randomised placebocontrolled trial.[Erratum appears in Ann Rheum Dis. 2009 Feb;68(2):296]. Annals of the Rheumatic Diseases 2008;67(11):1516-23.

\section{Emery 2009}

Emery P, Fleischmann RM, Moreland LW, Hsia EC, Strusberg I, Durez $\mathrm{P}$, et al. Golimumab, a human anti-tumor necrosis factor alpha monoclonal antibody, injected subcutaneously every four weeks in methotrexate-naive patients with active rheumatoid arthritis: twenty-four-week results of a phase III, multicenter, randomized, double-blind, placebo-controlled study of golimumab before methotrexate as first-line therapy for early-onset rheumatoid arthritis. Arthritis and Rheumatism 2009;60:2272-83.

\section{Eve 2009}

Eve HE, Linch D, Qian W, Ross M, Seymour JF, Smith P, et al. Toxicity of fludarabine and cyclophosphamide with or without rituximab as initial therapy for patients with previously untreated mantle cell lymphoma: results of a randomised phase II study. Leukemia and Lymphoma 2009;50:211-5.

\section{Feugier 2005}

Feugier P, Van Hoof A, Sebban C, Solal-Celigny P, Bouabdallah R, Ferme $\mathrm{C}$, et al. Long-term results of the R-CHOP study in the treatment of elderly patients with diffuse large B-cell lymphoma: a study by the Groupe d'Etude des Lymphomes de l'Adulte. Journal of Clinical Oncology 2005;23:4117-26.

\section{Fleischmann 2003}

Fleischmann RM, Schechtman J, Bennett R, Handel ML, Burmester GR, Tesser J, et al. Anakinra, a recombinant human interleukin-1 receptor antagonist (r-metHulL-1ra), in patients with rheumatoid arthritis: A large, international, multicenter, placebo-controlled trial. Arthritis and Rheumatism 2003;48(8):927-34.

\section{Fleischmann 2006}

Fleischmann RM, Tesser J, Schiff MH, Schechtman J, Burmester GR, Bennett R, et al. Safety of extended treatment with anakinra in patients with rheumatoid arthritis. Annals of the Rheumatic Diseases 2006;65(8):1006-12. 


\section{Fleischmann 2009}

Fleischmann R, Vencovsky J, Van Vollenhoven R F, Borenstein D, Box J, Coteur G, et al. Efficacy and safety of certolizumab pegol monotherapy every 4 weeks in patients with rheumatoid arthritis failing previous disease-modifying antirheumatic therapy: the FAST4WARD study. Annals of the Rheumatic Diseases 2009;68:805-11.

\section{Forstpointner 2002}

Forstpointner R, Hänel A, Repp R, Hermann S, Metzner B, Pott C, et al. [Increased response rate with rituximab in relapsed and refractory follicular and mantle cell lymphomas - results of a prospective randomized study of the German Low-Grade Lymphoma Study Group] [Rituximab zur remissionsinduktion bei rezidivierten und refraktären indolenten lymphomen und mantelzell-lymphomen - Ergebnisse einer prospektiv randomisierten studie der deutschenü studiengruppe für niedrig maligne lymphome (GLSG)]. Deutsche Medizinische Wochenschrift 2002;127(43):2253-8.

\section{Forstpointner 2004}

Forstpointner R, Dreyling M, Repp R, Hermann S, Hänel A, Metzner $B$, et al. The addition of rituximab to a combination of fludarabine, cyclophosphamide, mitoxantrone (FCM) significantly increases the response rate and prolongs survival as compared with FCM alone in patients with relapsed and refractory follicular and mantle cell lymphomas: results of a prospective randomized study of the German Low-Grade Lymphoma Study Group. Blood 2004;104(10):3064-71.

\section{Foster 2003}

Foster CS, Tufail F, Waheed NK, Chu D, Miserocchi E, Baltatzis S, et al. Efficacy of etanercept in preventing relapse of uveitis controlled by methotrexate. Archives of Ophthalmology 2003;121(4):437-40.

\section{Freedman 2009}

Freedman A, Neelapu SS, Nichols C, Robertson MJ, Djulbegovic B, Winter JN, et al. Placebo-controlled phase III trial of patient-specific immunotherapy with mitumprotimut$T$ and granulocyte-macrophage colony-stimulating factor after rituximab in patients with follicular lymphoma. Journal of Clinical Oncology 2009;27:3036-43.

\section{Furst 2003}

Furst DE, Schiff MH, Fleischmann RM, Strand V, Birbara CA, Compagnone $\mathrm{D}$, et al. Adalimumab, a fully human anti tumor necrosis factor-alpha monoclonal antibody, and concomitant standard antirheumatic therapy for the treatment of rheumatoid arthritis: results of STAR (Safety Trial of Adalimumab in Rheumatoid Arthritis). Journal of Rheumatology 2003;30(12):2563-71.

\section{Furst 2007}

Furst DE, Gaylis N, Bray V, Olech E, Yocum D, Ritter J, et al. Open-label, pilot protocol of patients with rheumatoid arthritis who switch to infliximab after an incomplete response to etanercept: the opposite study. Annals of the Rheumatic Diseases 2007;66:893-9.

\section{Gavalas 2007}

Gavalas E, Kountouras J, Stergiopoulos C, Zavos C, Gisakis D, Nikolaidis N, et al. Efficacy and safety of infliximab in steroiddependent ulcerative colitis patients. Hepato-Gastroenterology 2007;54(76):1074-9.

\section{Genovese 2002}

Genovese MC, Bathon JM, Martin RW, Fleischmann RM, Tesser JR, Schiff MH, et al. Etanercept versus methotrexate in patients with early rheumatoid arthritis: two-year radiographic and clinical outcomes. Arthritis and Rheumatism 2002;46(6):1443-50.

\section{Genovese 2005a}

Genovese MC, Becker J-C, Schiff M, Luggen M, Sherrer Y, Kremer J, et al. Abatacept for rheumatoid arthritis refractory to tumor necrosis factor alpha inhibition. [Erratum appears in $\mathrm{N}$ Engl J Med. 2005 Nov 24;353(21):2311]. New England Journal of Medicine 2005;353:1114-23.

\section{Genovese 2005b}

Genovese MC, Bathon JM, Fleischmann RM, Moreland LW, Martin RW, Whitmore JB, et al. Longterm safety, efficacy, and radiographic outcome with etanercept treatment in patients with early rheumatoid arthritis. Journal of Rheumatology 2005;32:1232-42.

\section{Genovese 2007}

Genovese MC, Mease PJ, Thomson GTD, Kivitz AJ, Perdok RJ, Weinberg MA, et al. Safety and efficacy of adalimumab in treatment of patients with psoriatic arthritis who had failed disease modifying antirheumatic drug therapy.[Erratum appears in J Rheumatol. 2007 Jun;34(6):1439]. Journal of Rheumatology 2007;34:1040-50.

\section{Genovese 2008a}

Genovese MC, McKay JD, Nasonov EL, Mysler EF, da Silva NA, Alecock E, et al. Interleukin-6 receptor inhibition with tocilizumab reduces disease activity in rheumatoid arthritis with inadequate response to disease-modifying antirheumatic drugs: the tocilizumab in combination with traditional diseasemodifying antirheumatic drug therapy study. Arthritis and Rheumatism 2008;58:2968-80.

\section{Genovese 2008b}

Genovese MC, Schiff M, Luggen M, Becker JC, Aranda R, Teng J, et al. Efficacy and safety of the selective co-stimulation modulator abatacept following 2 years of treatment in patients with rheumatoid arthritis and an inadequate response to anti-tumour necrosis factor therapy. Annals of the Rheumatic Diseases 2008;67:547-54.

\section{Ghielmini 2004}

Ghielmini M, Schmitz SF, Cogliatti SB, Pichert G, Hummerjohann J, Waltzer $\mathrm{U}$, et al. Prolonged treatment with rituximab in patients with follicular lymphoma significantly increases event-free survival and response duration compared with the standard weekly $\times 4$ schedule. Blood 2004;103(12):4416-23. 


\section{Ghielmini 2005}

Ghielmini M, Rufibach K, Salles G, Leoncini-Franscini L, LegerFalandry C, Cogliatti S, et al. Single agent rituximab in patients with follicular or mantle cell lymphoma: clinical and biological factors that are predictive of response and event-free survival as well as the effect of rituximab on the immune system: a study of the Swiss Group for Clinical Cancer Research (SAKK). Annals of Oncology 2005;16(10):1675-82.

\section{Gladman 2007}

Gladman DD, Mease PJ, Ritchlin CT, Choy EHS, Sharp JT, Ory PA, et al. Adalimumab for long-term treatment of psoriatic arthritis: forty-eight week data from the adalimumab effectiveness in psoriatic arthritis trial. Arthritis and Rheumatism 2007;56:476-88.

\section{Gordon 2006a}

Gordon KB, Gottlieb AB, Leonardi CL, Elewski BE, Wang A, Jahreis $A$, et al. Clinical response in psoriasis patients discontinued from and then reinitiated on etanercept therapy. [Erratum appears in J Dermatolog Treat. 2006;17(3):192]. Journal of Dermatological Treatment 2006;17:9-17.

\section{Gordon 2006b}

Gordon KB, Langley RG, Leonardi C, Toth D, Menter MA, Kang S, et al. Clinical response to adalimumab treatment in patients with moderate to severe psoriasis: double-blind, randomized controlled trial and open-label extension study. Journal of the American Academy of Dermatology 2006;55:598-606.

\section{Gorman 2002}

Gorman JD, Sack KE, Davis JC. Treatment of ankylosing spondylitis by inhibition of tumor necrosis factor alpha. New England Journal of Medicine 2002;346(18):1349-56.

\section{Gottlieb 2003a}

Gottlieb AB, Chaudhari U, Mulcahy LD, Li S, Dooley LT, Baker DG. Infliximab monotherapy provides rapid and sustained benefit for plaque-type psoriasis. Journal of the American Academy of Dermatology 2003;48(6):829-35.

\section{Gottlieb 2003b}

Gottlieb AB, Matheson RT, Lowe N, Krueger GG, Kang S, Goffe BS, et al. A randomized trial of etanercept as monotherapy for psoriasis. Archives of Dermatology 2003;139(12):1627-32.

\section{Gottlieb 2004}

Gottlieb AB, Evans R, Li S, Dooley LT, Guzzo CA, Baker D, et al. Infliximab induction therapy for patients with severe plaquetype psoriasis: a randomized, double-blind, placebo-controlled trial. Journal of the American Academy of Dermatology 2004;51(4):534-42.

\section{Haibel 2008}

Haibel H, Rudwaleit M, Listing J, Heldmann F, Wong RL, Kupper $\mathrm{H}$, et al. Efficacy of adalimumab in the treatment of axial spondylarthritis without radiographically defined sacroiliitis: results of a twelve-week randomized, double-blind, placebocontrolled trial followed by an open-label extension up to week fifty-two. Arthritis and Rheumatism 2008;58:1981-91.

\section{Hainsworth 2005}

Hainsworth JD, Litchy S, Shaffer DW, Lackey VL, Grimaldi M, Greco FA. Maximizing therapeutic benefit of rituximab: maintenance therapy versus re-treatment at progression in patients with indolent non-Hodgkin's lymphoma--a randomized phase II trial of the Minnie Pearl Cancer Research Network. Journal of Clinical Oncology 2005;23:1088-95.

\section{Hanauer 2002}

Hanauer SB, Feagan BG, Lichtenstein GR, Mayer LF, Schreiber S, Colombel JF, et al. Maintenance infliximab for Crohn's disease: the ACCENT I randomised trial. Lancet 2002;359(9317):1541-9.

\section{Hanauer 2006}

Hanauer SB, Sandborn WJ, Rutgeerts P, Fedorak RN, Lukas M, MacIntosh $D$, et al. Human anti-tumor necrosis factor monoclonal antibody (adalimumab) in Crohn's disease: the CLASSIC-I trial. Gastroenterology 2006;130:323-33.

\section{Hauser 2008}

Hauser SL, Waubant E, Arnold DL, Vollmer T, Antel J, Fox RJ, et al. B-cell depletion with rituximab in relapsingremitting multiple sclerosis. New England Journal of Medicine 2008;358:676-88.

\section{Hawker 2009}

Hawker K, O'Connor P, Freedman MS, Calabresi PA, Antel J, Simon J, et al. Rituximab in patients with primary progressive multiple sclerosis: results of a randomized double-blind placebo-controlled multicenter trial. Annals of Neurology 2009;66:460-71.

\section{Herold 2000}

Herold M, Strohl J, Assmann M, Eschenburg H, Franke A, Freund $M$, et al. Acute toxicity of mitoxantrone, chlorambucil and prednisolone (MCP) versus MCP plus rituximab in low-grade non-Hodgkin's lymphoma - Interim results of a phase III trial [Akute Toxizität von Mitoxantron, Chlorambucil und Prednisolon (MCP) versus MCP plus Rituximab bei niedrig-malignen NonHodgkin-Lymphomen - erste Ergebnisse einer Phase-III Studie]. Onkologie 2000;23(2):164-6.

\section{Herold 2007}

Herold M, Haas A, Srock S, Neser S, Al-Ali K, Neubauer A, et al. Rituximab added to first-line mitoxantrone, chlorambucil, and prednisolone chemotherapy followed by interferon maintenance prolongs survival in patients with advanced follicular lymphoma: an East German Study Group Hematology and Oncology Study. Journal of Clinical Oncology 2007;25:1986-92.

\section{Hiddemann 2005}

Hiddemann W, Kneba M, Dreyling M, Schmitz N, Lengfelder E, Schmits R, et al. Frontline therapy with rituximab added to the combination of cyclophosphamide, doxorubicin, vincristine, and prednisone (CHOP) significantly improves the outcome for patients with advanced-stage follicular lymphoma compared with therapy with $\mathrm{CHOP}$ alone: results of a prospective randomized study of the German Low-Grade Lymphoma Study Group. Blood 2005;106:3725-32. 


\section{Inman 2008}

Inman RD, Davis JC Jr, Van der Heijde D, Diekman L, Sieper J, Kim S Il, et al. Efficacy and safety of golimumab in patients with ankylosing spondylitis: results of a randomized, double-blind, placebo-controlled, phase III trial. Arthritis and Rheumatism 2008;58:3402-12.

\section{Jarnerot 2005}

Jarnerot G, Hertervig E, Friis-Liby I, Blomquist L, Karlen P, Granno C, et al. Infliximab as rescue therapy in severe to moderately severe ulcerative colitis: a randomized, placebocontrolled study. Gastroenterology 2005;128:1805-11.

\section{Jatoi 2007}

Jatoi A, Dakhil SR, Nguyen PL, Sloan JA, Kugler JW, Rowland KM Jr, et al. A placebo-controlled double blind trial of etanercept for the cancer anorexia/weight loss syndrome: results from N0OC1 from the North Central Cancer Treatment Group. Cancer 2007;110:1396-403.

\section{Johnsen 2006}

Johnsen AK, Schiff MH, Mease PJ, Moreland LW, Maier AL, Coblyn JS, et al. Comparison of 2 doses of etanercept (50 vs 100 $\mathrm{mg}$ ) in active rheumatoid arthritis: a randomized double blind study. Journal of Rheumatology 2006;33:659-64.

\section{Jones 2008}

Jones G, Sebba A, Gu J, Lowenstein MB, Calvo A, GomezReino JJ, et al. Comparison of tocilizumab monotherapy versus methotrexate monotherapy in patients with moderate to severe rheumatoid arthritis: The AMBITION study. Annals of the Rheumatic Diseases 2008;69:88-96.

\section{Kavanaugh 2000}

Kavanaugh A, St Clair EW, McCune WJ, Braakman T, Lipsky P. Chimeric anti-tumor necrosis factor-alpha monoclonal antibody treatment of patients with rheumatoid arthritis receiving methotrexate therapy. Journal of Rheumatology 2000;27(4):841-50

\section{Kavanaugh 2007}

Kavanaugh A, Krueger GG, Beutler A, Guzzo C, Zhou B, Dooley LT, et al. Infliximab maintains a high degree of clinical response in patients with active psoriatic arthritis through 1 year of treatment: results from the IMPACT 2 trial. Annals of the Rheumatic Diseases 2007;66:498-505.

\section{Kavanaugh 2009}

Kavanaugh A, McInnes I, Mease P, Krueger GG, Gladman D, Gomez-Reino J, et al. Golimumab, a new human tumor necrosis factor alpha antibody, administered every four weeks as a subcutaneous injection in psoriatic arthritis: Twenty-four-week efficacy and safety results of a randomized, placebo-controlled study. Arthritis and Rheumatism 2009;60:976-86.

\section{Kay 2008}

Kay J, Matteson EL, Dasgupta B, Nash P, Durez P, Hall S, et al. Golimumab in patients with active rheumatoid arthritis despite treatment with methotrexate: a randomized, doubleblind, placebo-controlled, dose-ranging study. Arthritis and Rheumatism 2008;58:964-75.

\section{Keystone 2004a}

Keystone EC, Kavanaugh AF, Sharp JT, Tannenbaum H, Hua Y, Teoh LS, et al. Radiographic, clinical, and functional outcomes of treatment with adalimumab (a human anti-tumor necrosis factor monoclonal antibody) in patients with active rheumatoid arthritis receiving concomitant methotrexate therapy: a randomized, placebo-controlled, 52-week trial. Arthritis and Rheumatism 2004;50(5):1400-11.

\section{Keystone 2004b}

Keystone EC, Schiff MH, Kremer JM, Kafka S, Lovy M, DeVries T, et al. Once-weekly administration of $50 \mathrm{mg}$ etanercept in patients with active rheumatoid arthritis: results of a multicenter, randomized, double-blind, placebo-controlled trial. Arthritis and Rheumatism 2004;50(2):353-63.

\section{Keystone 2007}

Keystone E, Fleischmann R, Emery P, Furst DE, Van Vollenhoven R, Bathon J, et al. Safety and efficacy of additional courses of rituximab in patients with active rheumatoid arthritis: An open-label extension analysis. Arthritis and Rheumatism 2007;56:3896-908.

\section{Keystone 2008}

Keystone E, Van der Heijde D, Mason D Jr, Landewe R, Vollenhoven RV, Combe B, et al. Certolizumab pegol plus methotrexate is significantly more effective than placebo plus methotrexate in active rheumatoid arthritis: findings of a fifty-two-week, phase III, multicenter, randomized, doubleblind, placebo-controlled, parallel-group study.[Erratum appears in Arthritis Rheum. 2009 May;60(5):1249]. Arthritis and Rheumatism 2008;58:3319-29.

\section{Keystone 2009a}

Keystone EC, Genovese MC, Klareskog L, Hsia EC, Hall ST, Miranda PC, et al. Golimumab, a human antibody to tumour necrosis factor \{alpha\} given by monthly subcutaneous injections, in active rheumatoid arthritis despite methotrexate therapy: the GO-FORWARD Study. Annals of the Rheumatic Diseases 2009;68:789-96.

\section{Kim 2007}

Kim HY, Lee SK, Song YW, Yoo DH, Koh EM, Yoo B, et al. A randomized, double-blind, placebo-controlled, phase III study of the human anti-tumor necrosis factor antibody adalimumab administered as subcutaneous injections in Korean rheumatoid arthritis patients treated with methotrexate. APLAR Journal of Rheumatology 2007;10:9-16.

\section{Klareskog 2004}

Klareskog L, Van der Heijde D, De Jager J P, Gough A, Kalden J, Malaise M, et al. Therapeutic effect of the combination of etanercept and methotrexate compared with each treatment alone in patients with rheumatoid arthritis: double-blind randomised controlled trial. Lancet 2004;363(9410):675-81.

\section{Klareskog 2006}

Klareskog L, Gaubitz M, Rodriguez-Valverde V, Malaise M, Dougados M, Wajdula J, et al. A long-term, open-label trial of the safety and efficacy of etanercept (Enbrel) in patients with rheumatoid arthritis not treated with other disease- 
modifying antirheumatic drugs. Annals of the Rheumatic Diseases 2006;65:1578-84.

\section{Kremer 2003}

Kremer JM, Weinblatt ME, Bankhurst AD, Bulpitt KJ, Fleischmann RM, Jackson CG, et al. Etanercept added to background methotrexate therapy in patients with rheumatoid arthritis: continued observations. Arthritis and Rheumatism 2003;48(6):1493-9.

\section{Kremer 2005}

Kremer JM, Dougados M, Emery P, Durez P, Sibilia J, Shergy W, et al. Treatment of rheumatoid arthritis with the selective costimulation modulator abatacept: twelve-month results of a phase iib, double-blind, randomized, placebo-controlled trial. [Erratum appears in Arthritis Rheum. 2005 Oct;52(10):3321]. Arthritis and Rheumatism 2005;52:2263-71.

\section{Kremer 2006}

Kremer JM, Genant HK, Moreland LW, Russell AS, Emery P, Abud-Mendoza C, et al. Effects of abatacept in patients with methotrexate-resistant active rheumatoid arthritis: a randomized trial.[Summary for patients in Ann Intern Med. 2006 Jun 20;144(12):I18; PMID: 16785473]. Annals of Internal Medicine 2006;144:865-76.

\section{Krueger 2006}

Krueger GG, Elewski B, Papp K, Wang A, Zitnik R, Jahreis A. Patients with psoriasis respond to continuous open-label etanercept treatment after initial incomplete response in a randomized, placebo-controlled trial. Journal of the American Academy of Dermatology 2006;54:S112-9.

\section{Lan 2004}

Lan JL, Chou SJ, Chen DY, Chen YH, Hsieh TY, Young M. A comparative study of etanercept plus methotrexate and methotrexate alone in Taiwanese patients with active rheumatoid arthritis: a 12-week, double-blind, randomized, placebo-controlled study. Journal of the Formosan Medical Association 2004;103(8):618-23.

\section{Leonardi 2003}

Leonardi CL, Powers JL, Matheson RT, Goffe BS, Zitnik R, Wang A, et al. Etanercept as monotherapy in patients with psoriasis. New England Journal of Medicine 2003;349(21):2014-22.

\section{Lin 2005}

Lin T-Y, Zhang H-Y, Huang Y, Guan Z-Z, Shen T, Shi Y-K, et al. [Comparison between $\mathrm{R}-\mathrm{CHOP}$ regimen and $\mathrm{CHOP}$ regimen in treating naive diffuse large B-cell lymphoma in China - a multicenter randomized trial]. Aizheng: Chinese Journal of Cancer 2005;24(12):1421-6.

\section{Maini 1998}

Maini RN, Breedveld FC, Kalden JR, Smolen JS, Davis D, Macfarlane JD, et al. Therapeutic efficacy of multiple intravenous infusions of anti-tumor necrosis factor alpha monoclonal antibody combined with low-dose weekly methotrexate in rheumatoid arthritis. Arthritis and Rheumatism 1998;41(9):1552-63.

\section{Maini 1999}

Maini R, St Clair E W, Breedveld F, Furst D, Kalden J, Weisman M, et al. Infliximab (chimeric anti-tumour necrosis factor alpha monoclonal antibody) versus placebo in rheumatoid arthritis patients receiving concomitant methotrexate: a randomised phase III trial. ATTRACT Study Group. Lancet 1999;354(9194):1932-9.

\section{Maini 2006}

Maini RN, Taylor PC, Szechinski J, Pavelka K, Broll J, Balint G, et al. Double-blind randomized controlled clinical trial of the interleukin- 6 receptor antagonist, tocilizumab, in European patients with rheumatoid arthritis who had an incomplete response to methotrexate.[Erratum appears in Arthritis Rheum. 2008 Mar;58(3):887]. Arthritis and Rheumatism 2006;54(9):2817-29.

\section{Marcus 2005}

Marcus R, Imrie K, Belch A, Cunningham D, Flores E, Catalano J, et al. CVP chemotherapy plus rituximab compared with CVP as first-line treatment for advanced follicular lymphoma. Blood 2005;105(4):1417-23.

\section{Mariette 2004}

Mariette X, Ravaud P, Steinfeld S, Baron G, Goetz J, Hachulla E, et al. Inefficacy of infliximab in primary Sjögren's syndrome: results of the randomized, controlled Trial of Remicade in Primary Sjögren's Syndrome (TRIPSS). Arthritis and Rheumatism 2004;50(4):1270-6.

\section{Martinez-Taboada 2008}

Martinez-Taboada VM, Rodriguez-Valverde V, Carreno L, LopezLongo J, Figueroa M, Belzunegui J, et al. A double-blind placebo controlled trial of etanercept in patients with giant cell arteritis and corticosteroid side effects. Annals of the Rheumatic Diseases 2008;67(5):625-30.

\section{Marzo-Ortega 2005}

Marzo-Ortega H, McGonagle D, Jarrett S, Haugeberg G, Hensor E, O'Connor P, et al. Infliximab in combination with methotrexate in active ankylosing spondylitis: a clinical and imaging study. Annals of the Rheumatic Diseases 2005;64(11):1568-75.

\section{Mease 2000}

Mease PJ, Goffe BS, Metz J, VanderStoep A, Finck B, Burge DJ. Etanercept in the treatment of psoriatic arthritis and psoriasis: a randomised trial. Lancet 2000;356(9227):385-90.

\section{Mease 2004}

Mease PJ, Kivitz AJ, Burch FX, Siegel EL, Cohen SB, Ory P, et al. Etanercept treatment of psoriatic arthritis: safety, efficacy, and effect on disease progression. Arthritis and Rheumatism 2004;50(7):2264-72.

\section{Mease 2005}

Mease PJ, Gladman DD, Ritchlin CT, Ruderman EM, Steinfeld SD, Choy EHS, et al. Adalimumab for the treatment of patients with moderately to severely active psoriatic arthritis: results of a double-blind, randomized, placebo-controlled trial. Arthritis and Rheumatism 2005;52(10):3279-89. 


\section{Mease 2006}

Mease PJ, Kivitz AJ, Burch FX, Siegel EL, Cohen SB, Ory P, et al. Continued inhibition of radiographic progression in patients with psoriatic arthritis following 2 years of treatment with etanercept. Jourunal of Rheumatology 2006;33(4):712-21.

\section{Mease 2009}

Mease PJ, Ory P, Sharp JT, Ritchlin CT, Van den Bosch F, Wellborne $F$, et al. Adalimumab for long-term treatment of psoriatic arthritis: 2-year data from the Adalimumab Effectiveness in Psoriatic Arthritis Trial (ADEPT). Annals of the Rheumatic Diseases 2009;68(5):702-9.

\section{Menter 2007}

Menter A, Feldman SR, Weinstein GD, Papp K, Evans R, Guzzo C, et al. A randomized comparison of continuous vs. intermittent infliximab maintenance regimens over 1 year in the treatment of moderate-to-severe plaque psoriasis. Journal of the American Academy of Dermatology 2007;56(1):31.e1-15.

\section{Menter 2008}

Menter A, Tyring SK, Gordon K, Kimball AB, Leonardi CL, Langley RG, et al. Adalimumab therapy for moderate to severe psoriasis: A randomized, controlled phase III trial. Journal of the Americn Academy of Dermatology 2008;58(1):106-15.

\section{Miyasaka 2008}

Miyasaka N, Change Study Investigators. Clinical investigation in highly disease-affected rheumatoid arthritis patients in Japan with adalimumab applying standard and general evaluation: the CHANGE study. Modern Rheumatology 2008;18(3):252-62.

\section{Monk 2006}

Monk JI, Phillips G, Waite R, Kuhn J, Schaaf LJ, Otterson GA, et al. Assessment of tumor necrosis factor alpha blockade as an intervention to improve tolerability of dose-intensive chemotherapy in cancer patients. Journal of Clinical Oncology 2006;24(12):1852-9.

\section{Moreland 1999}

Moreland LW, Schiff MH, Baumgartner SW, Tindall EA, Fleischmann RM, Bulpitt KJ, et al. Etanercept therapy in rheumatoid arthritis. A randomized, controlled trial. Annals of Internal Medicine 1999;130(6):478-86.

\section{Naveau 2004}

Naveau S, Chollet-Martin S, Dharancy S, Mathurin P, Jouet P, Piquet MA, et al. A double-blind randomized controlled trial of infliximab associated with prednisolone in acute alcoholic hepatitis. Hepatology 2004;39(5):1390-7.

\section{Nishimoto 2009}

Nishimoto N, Miyasaka N, Yamamoto K, Kawai S, Takeuchi T, Azuma J. Long-term safety and efficacy of tocilizumab, an antiIL-6 receptor monoclonal antibody, in monotherapy, in patients with rheumatoid arthritis (the STREAM study): evidence of safety and efficacy in a 5-year extension study. Annals of the Rheumatic Diseases 2009;68(10):1580-4.

\section{Nuki 2002}

Nuki G, Bresnihan B, Bear MB, McCabe D, European Group Of Clinical Investigators. Long-term safety and maintenance of clinical improvement following treatment with anakinra (recombinant human interleukin-1 receptor antagonist) in patients with rheumatoid arthritis: extension phase of a randomized, double-blind, placebo-controlled trial. Arthritis and Rheumatism 2002;46(11):2838-46.

\section{Ortonne 2008}

Ortonne JP, Griffiths CEM, Dauden E, Strohal R, Robertson D, Pedersen $\mathrm{R}$, et al. Efficacy and safety of continuous versus paused etanercept teatment in patients with moderate-tosevere psoriasis over 54 weeks: The CRYSTEL study. Expert Review of Dermatology 2008;3(6):657-65.

\section{Papp 2005}

Papp KA, Tyring S, Lahfa M, Prinz J, Griffiths CEM, Nakanishi AM, et al. A global phase III randomized controlled trial of etanercept in psoriasis: safety, efficacy, and effect of dose reduction. British Journal of Dermatology 2005;152(6):1304-12.

\section{Pavelka 2009}

Pavelka K, Jarosova K, Suchy D, Senolt L, Chroust K, Dusek L, et al. Increasing the infliximab dose in rheumatoid arthritis patients: a randomised, double blind study failed to confirm its efficacy. Annals of the Rheumatic Diseases 2009;68(8):1285-9.

\section{Pescovitz 2009}

Pescovitz MD, Greenbaum CJ, Krause-Steinrauf H, Becker DJ, Gitelman SE, Goland R, et al. Rituximab, B-lymphocyte depletion, and preservation of beta-cell function. New England Journal of Medicine 2009;361(22):2143-52.

\section{Pfreundschuh 2006}

Pfreundschuh M, Trumper L, Osterborg A, Pettengell R, Trneny M, Imrie K, et al. CHOP-like chemotherapy plus rituximab versus $\mathrm{CHOP}$-like chemotherapy alone in young patients with good-prognosis diffuse large-B-cell lymphoma: a randomised controlled trial by the MabThera International Trial (MInT) Group. Lancet: Oncology 2006;7(5):379-91.

\section{Present 1999}

Present DH, Rutgeerts P, Targan S, Hanauer SB, Mayer L, Van Hogezand RA, et al. Infliximab for the treatment of fistulas in patients with Crohn's disease. New England Journal of Medicine 1999;340(18):1398-405.

\section{Rau 2004}

Rau R, Simianer S, Van Riel PL, Van de Putte LB, Krüger K, Schattenkirchner M, et al. Rapid alleviation of signs and symptoms of rheumatoid arthritis with intravenous or subcutaneous administration of adalimumab in combination with methotrexate. Scandinavian Journal of Rheumatology 2004;33(3):145-53.

\section{Reich 2005}

Reich K, Nestle F, Papp K, Ortonne J-P, Evans R, Guzzo C, et al. Infliximab induction and maintenance therapy for moderateto-severe psoriasis: a phase III, multicentre, double-blind trial. Lancet 2005;366(9494):1367-74. 


\section{Rennard 2007}

Rennard SI, Fogarty C, Kelsen S, Long W, Ramsdell J, Allison J, et al. The safety and efficacy of infliximab in moderate to severe chronic obstructive pulmonary disease. American Journal of Respiratory and Critical Care Medicine 2007;175(9):926-34.

\section{Rossman 2006}

Rossman MD, Newman LS, Baughman RP, Teirstein A, Weinberger SE, Miller W Jr, et al. A double-blinded, randomized, placebo-controlled trial of infliximab in subjects with active pulmonary sarcoidosis. Sarcoidosis, Vasculitis, and Diffuse Lung Diseases 2006;23(3):201-8.

\section{Rouhani 2005}

Rouhani FN, Meitin CA, Kaler M, Miskinis-Hilligoss D, Stylianou M, Levine SJ. Effect of tumor necrosis factor antagonism on allergen-mediated asthmatic airway inflammation. Respiratory Medicine 2005;99(9):1175-82.

\section{Rutgeerts 1999}

Rutgeerts P, D'Haens G, Targan S, Vasiliauskas E, Hanauer SB, Present $\mathrm{DH}$, et al. Efficacy and safety of retreatment with anti-tumor necrosis factor antibody (infliximab) to maintain remission in Crohn's disease. Gastroenterology 1999;117(4):761-9.

\section{Salles 2008}

Salles GA, Mounier N, De Guibert S, Morschhauser F, Doyen C, Rossi J, et al. Rituximab combined with chemotherapy and interferon in follicular lymphoma patients: results of the GELAGOELAMS FL2000 study. Blood 2007;112(13):4824-31.

\section{Salvarani 2007}

Salvarani C, Macchioni P, Manzini C, Paolazzi G, Trotta A Manganelli $P$, et al. Infliximab plus prednisone or placebo plus prednisone for the initial treatment of polymyalgia rheumatica: a randomized trial.[Summary for patients in Ann Intern Med. 2007 May 1;146(9):I20; PMID: 17470827]. Annals of Internal Medicine 2007;146(9):631-9.

\section{Sandborn 2001}

Sandborn WJ, Hanauer SB, Katz S, Safdi M, Wolf DG, Baerg RD, et al. Etanercept for active Crohn's disease: a randomized, double-blind, placebo-controlled trial. Gastroenterology 2001;121(5):1088-94.

\section{Sandborn 2007a}

Sandborn WJ, Feagan BG, Stoinov S, Honiball PJ, Rutgeerts P, Mason D, et al. Certolizumab pegol for the treatment of Crohn's disease. New England Journal of Medicine 2007;357(3):228-38.

\section{Sandborn 2007b}

Sandborn WJ, Hanauer SB, Rutgeerts P, Fedorak RN, Lukas M, Maclntosh DG, et al. Adalimumab for maintenance treatment of Crohn's disease: results of the CLASSIC II trial. Gut 2007;56(9):1232-9.

\section{Sandborn 2007c}

Sandborn WJ, Rutgeerts P, Enns R, Hanauer SB, Colombel JF, Panaccione R, et al. Adalimumab induction therapy for Crohn disease previously treated with infliximab: a randomized
trial.[Summary for patients in Ann Intern Med. 2007 Jun 19;146(12):I20; PMID: 17470825]. Annals of Internal Medicine 2007;146(12):829-38.

\section{Sandborn 2009}

Sandborn WJ, Rutgeerts P, Feagan BG, Reinisch W, Olson A, Johanns J, et al. Colectomy rate comparison after treatment of ulcerative colitis with placebo or infliximab. Gastroenterology 2009;137(4):1250-60.

\section{Sands 2001}

Sands BE, Tremaine WJ, Sandborn WJ, Rutgeerts PJ, Hanauer SB, Mayer L, et al. Infliximab in the treatment of severe, steroid-refractory ulcerative colitis: a pilot study. Inflammatory Bowel Diseases 2001;7(2):83-8.

\section{Sany 2005}

Sany J, Kaiser MJ, Jorgensen C, Trape G. Study of the tolerance of infliximab infusions with or without betamethasone premedication in patients with active rheumatoid arthritis. Annals of the Rheumatic Diseases 2005;64(11):1647-9.

\section{Schiff 2004}

Schiff MH, DiVittorio G, Tesser J, Fleischmann R, Schechtman J, Hartman S, et al. The safety of anakinra in high-risk patients with active rheumatoid arthritis: six-month observations of patients with comorbid conditions. Arthritis and Rheumatism 2004;50(6):1752-60

\section{Schiff 2008}

Schiff M, Keiserman M, Codding C, Songcharoen S, Berman A, Nayiager S, et al. Efficacy and safety of abatacept or infliximab vs placebo in ATTEST: a phase III, multi-centre, randomised, double-blind, placebo-controlled study in patients with rheumatoid arthritis and an inadequate response to methotrexate. Annals of the Rheumatic Diseases 2008;67(8):1096-103.

\section{Schreiber 2005}

Schreiber S, Rutgeerts P, Fedorak RN, Khaliq-Kareemi M, Kamm MA, Boivin M, et al. A randomized, placebo-controlled trial of certolizumab pegol (CDP870) for treatment of Crohn's disease.[Erratum appears in Gastroenterology. 2005 Nov;129(5):1808 Note: Dosage error in article text]. Gastroenterology 2005;129(3):807-18.

\section{Schreiber 2007}

Schreiber S, Khaliq-Kareemi M, Lawrance IC, Thomsen OO, Hanauer SB, McColm J, et al. Maintenance therapy with certolizumab pegol for Crohn's disease. [Erratum appears in $\mathrm{N}$ Engl J Med. 2007 Sep 27;357(13):1357]. New England Journal of Medicine 2007;357(3):239-50.

\section{Smolen 2008}

Smolen JS, Beaulieu A, Rubbert-Roth A, Ramos-Remus C, Rovensky J, Alecock E, et al. Effect of interleukin-6 receptor inhibition with tocilizumab in patients with rheumatoid arthritis (OPTION study): a double-blind, placebo-controlled, randomised trial. Lancet 2008;371(9617):987-97. 


\section{Smolen 2009a}

Smolen J, Landewe RB, Mease P, Brzezicki J, Mason D, Luijtens $\mathrm{K}$, et al. Efficacy and safety of certolizumab pegol plus methotrexate in active rheumatoid arthritis: the RAPID 2 study. A randomised controlled trial. Annals of the Rheumatic Diseases 2009;68(6):797-804.

\section{Smolen 2009b}

Smolen JS, Kay J, Doyle MK, Landewe R, Matteson EL, Wollenhaupt J, et al. Golimumab in patients with active rheumatoid arthritis after treatment with tumour necrosis factor alpha inhibitors (GO-AFTER study): a multicentre, randomised, double-blind, placebo-controlled, phase III trial. [Erratum appears in Lancet. 2009 Oct 24;374(9699):1422]. Lancet 2009;374(9685):210-21.

\section{Spahr 2002}

Spahr L, Rubbia-Brandt L, Frossard JL, Giostra E, Rougemont AL, Pugin J, et al. Combination of steroids with infliximab or placebo in severe alcoholic hepatitis: a randomized controlled pilot study. Journal of Hepatology 2002;37(4):448-55.

\section{St Clair 2004}

St Clair EW, Van der Heijde DM, Smolen JS, Maini RN, Bathon JM, Emery P, et al. Combination of infliximab and methotrexate therapy for early rheumatoid arthritis: a randomized, controlled trial. Arthritis and Rheumatism 2004;50(11):3432-43.

\section{Torre-Amione 2007}

Torre-Amione G, Wallace CK, Young JB, Koerner MM, Thohan V, McRee S, et al. The effect of etanercept on cardiac transplant recipients: a study of TNFalpha antagonism and cardiac allograft hypertrophy. Transplantation 2007;84(4):480-3.

\section{Tyden 2009}

Tyden G, Genberg H, Tollemar J, Ekberg H, Persson NH, Tufveson G, et al. A randomized, double blind, placebocontrolled, study of single-dose rituximab as induction in renal transplantation. Transplantation 2009;87(9):1325-9.

\section{Tyring 2007}

Tyring S, Gordon KB, Poulin Y, Langley RG, Gottlieb AB, Dunn M, et al. Long-term safety and efficacy of $50 \mathrm{mg}$ of etanercept twice weekly in patients with psoriasis. Archives of Dermatology 2007;143(6):719-26.

\section{Uppal 2009}

Uppal SS, Hayat SJ, Raghupathy R. Efficacy and safety of infliximab in active SLE: a pilot study. Lupus 2009;18(8):690-7.

\section{Van de Kerkhof 2008}

Van de Kerkhof PC, Segaert S, Lahfa M, Luger TA, Karolyi Z, Kaszuba A, et al. Once weekly administration of etanercept 50 $\mathrm{mg}$ is efficacious and well tolerated in patients with moderateto-severe plaque psoriasis: a randomized controlled trial with open-label extension. British Journal of Dermatology 2008;159(5):1177-85.

\section{Van de Putte 2003}

Van de Putte LB, Rau R, Breedveld FC, Kalden JR, Malaise MG, Van Riel PL, et al. Efficacy and safety of the fully human anti-tumour necrosis factor alpha monoclonal antibody adalimumab (D2E7) in DMARD refractory patients with rheumatoid arthritis: a 12 week, phase II study. Annals of the Rheumatic Diseases 2003;62(12):1168-77.

\section{Van de Putte 2004}

Van de Putte L B, Atkins C, Malaise M, Sany J, Russell A S, Van Riel P L, et al. Efficacy and safety of adalimumab as monotherapy in patients with rheumatoid arthritis for whom previous disease modifying antirheumatic drug treatment has failed. Annals of the Rheumatic Diseases 2004;63(5):508-16.

\section{Van Den Bosch 2002}

Van Den Bosch F, Kruithof E, Baeten D, Herssens A, De Keyser F, Mielants $\mathrm{H}$, et al. Randomized double-blind comparison of chimeric monoclonal antibody to tumor necrosis factor alpha (infliximab) versus placebo in active spondylarthropathy. Arthritis and Rheumatism 2002;46(3):755-65.

\section{Van der Bijl 2009}

Van der Bijl AE, Teng YK, Van Oosterhout M, Breedveld FC, Allaart CF, Huizinga TW, et al. Efficacy of intraarticular infliximab in patients with chronic or recurrent gonarthritis: a clinical randomized trial. Arthritis and Rheumatism 2009;61(7):974-8.

\section{Van der Heijde 2005}

Van der Heijde D, Dijkmans B, Geusens P, Sieper J, DeWoody K, Williamson $P$, et al. Efficacy and safety of infliximab in patients with ankylosing spondylitis: results of a randomized, placebo-controlled trial (ASSERT). Arthritis and Rheumatism 2005;52(2):582-91.

\section{Van der Heijde 2006a}

Van der Heijde D, Kivitz A, Schiff MH, Sieper J, Dijkmans BAC, Braun J, et al. Efficacy and safety of adalimumab in patients with ankylosing spondylitis: results of a multicenter, randomized, double-blind, placebo-controlled trial. Arthritis and Rheumatism 2006;54(7):2136-46.

\section{Van der Heijde 2006b}

Van der Heijde D, Da Silva JC, Dougados M, Geher P, Van der Horst-Bruinsma I, Juanola X, et al. Etanercept $50 \mathrm{mg}$ once weekly is as effective as $25 \mathrm{mg}$ twice weekly in patients with ankylosing spondylitis. Annals of the Rheumatic Diseases 2006;65(12):1572-7.

\section{Van der Heijde 2007}

Van der Heijde D, Klareskog L, Landewe R, Bruyn GA, Cantagrel A, Durez P, et al. Disease remission and sustained halting of radiographic progression with combination etanercept and methotrexate in patients with rheumatoid arthritis. Arthritis and Rheumatism 2007;56(12):3928-39.

\section{Van der Heijde 2008a}

Van der Heijde D, Burmester G, Melo-Gomes J, Codreanu C, Mola EM, Pedersen R, et al. The safety and efficacy of adding etanercept to methotrexate or methotrexate to etanercept in moderately active rheumatoid arthritis patients previously 
treated with monotherapy. Annals of the Rheumatic Diseases 2008;67(2):182-8.

\section{Van der Heijde 2009}

Van der Heijde D, Schiff MH, Sieper J, Kivitz AJ, Wong RL, Kupper $\mathrm{H}$, et al. Adalimumab effectiveness for the treatment of ankylosing spondylitis is maintained for up to 2 years: longterm results from the ATLAS trial. Annals of the Rheumatic Diseases 2009;68(6):922-9.

\section{Van der Vaart 2005}

Van der Vaart H, Koeter GH, Postma DS, Kauffman HF, ten Hacken NHT. First study of infliximab treatment in patients with chronic obstructive pulmonary disease. American Journal of Respiratory and Critical Care Medicine 2005;172(4):465-9.

\section{Van Vollenhoven 2009}

Van Vollenhoven RF, Ernestam S, Geborek P, Petersson IF, Coster L, Waltbrand E, et al. Addition of infliximab compared with addition of sulfasalazine and hydroxychloroquine to methotrexate in patients with early rheumatoid arthritis (Swefot trial): 1-year results of a randomised trial. Lancet 2009;374(9688):459-66.

\section{Wegener's 2005}

Wegener's Granulomatosis Etanercept Trial Research Group. Etanercept plus standard therapy for Wegener's granulomatosis. New England Journal of Medicine 2005;352(4):351-61.

\section{Weinblatt 1999}

Weinblatt ME, Kremer JM, Bankhurst AD, Bulpitt KJ, Fleischmann RM, Fox RI, et al. A trial of etanercept, a recombinant tumor necrosis factor receptor:Fc fusion protein, in patients with rheumatoid arthritis receiving methotrexate. New England Journal of Medicine 1999;340(4):253-9.

\section{Weinblatt 2003}

Weinblatt ME, Keystone EC, Furst DE, Moreland LW, Weisman MH, Birbara CA, et al. Adalimumab, a fully human anti-tumor necrosis factor alpha monoclonal antibody, for the treatment of rheumatoid arthritis in patients taking concomitant methotrexate: the ARMADA trial. Arthritis and Rheumatism 2003;48(1):35-45.

\section{Weinblatt 2006a}

Weinblatt M, Combe B, Covucci A, Aranda R, Becker JC, Keystone E. Safety of the selective costimulation modulator abatacept in rheumatoid arthritis patients receiving background biologic and nonbiologic disease-modifying antirheumatic drugs: A one-year randomized, placebocontrolled study. Arthritis and Rheumatism 2006;54(9):2807-16.

\section{Weinblatt 2006b}

Weinblatt ME, Keystone EC, Furst DE, Kavanaugh AF, Chartash EK, Segurado OG. Long term efficacy and safety of adalimumab plus methotrexate in patients with rheumatoid arthritis: ARMADA 4 year extended study. Annals of the Rheumatic Diseases 2006;65(6):753-9.

\section{Weinblatt 2007}

Weinblatt M, Schiff M, Goldman A, Kremer J, Luggen M, Li T, et al. Selective costimulation modulation using abatacept in patients with active rheumatoid arthritis while receiving etanercept: a randomised clinical trial. Annals of the Rheumatic Diseases 2007;66:228-34.

\section{Weinblatt 2008}

Weinblatt ME, Schiff MH, Ruderman EM, Bingham CO 3rd, Li J, Louie J, et al. Efficacy and safety of etanercept $50 \mathrm{mg}$ twice a week in patients with rheumatoid arthritis who had a suboptimal response to etanercept $50 \mathrm{mg}$ once a week: results of a multicenter, randomized, double-blind, active drugcontrolled study. Arthritis and Rheumatism 2008;58(7):1921-30.

\section{Weisman 2003}

Weisman MH, Moreland LW, Furst DE, Weinblatt ME, Keystone EC, Paulus HE, et al. Efficacy, pharmacokinetic, and safety assessment of adalimumab, a fully human anti-tumor necrosis factor-alpha monoclonal antibody, in adults with rheumatoid arthritis receiving concomitant methotrexate: a pilot study. Clinical Therapeutics 2003;25(6):1700-21.

\section{Weisman 2007}

Weisman MH, Paulus HE, Burch FX, Kivitz AJ, Fierer J, Dunn M, et al. A placebo-controlled, randomized, double-blinded study evaluating the safety of etanercept in patients with rheumatoid arthritis and concomitant comorbid diseases. Rheumatology 2007;46(7):1122-5.

\section{Wenzel 2009}

Wenzel SE, Barnes PJ, Bleecker ER, Bousquet J, Busse W, Dahlen SE, et al. A randomized, double-blind, placebocontrolled study of tumor necrosis factor-alpha blockade in severe persistent asthma. American Journal of Respiratory and Critical Care Medicine 2009;179(7):549-58.

\section{Westhovens 2006}

Westhovens R, Yocum D, Han J, Berman A, Strusberg I, Geusens $P$, et al. The safety of infliximab, combined with background treatments, among patients with rheumatoid arthritis and various comorbidities: a large, randomized, placebo-controlled trial.[Erratum appears in Arthritis Rheum. 2007 May;56(5):1675 Note: Dosage error in article text]. Arthritis and Rheumatism 2006;54(4):1075-86.

\section{Westhovens 2009a}

Westhovens R, Kremer JM, Moreland LW, Emery P, Russell AS, $\mathrm{Li}$ T, et al. Safety and efficacy of the selective costimulation modulator abatacept in patients with rheumatoid arthritis receiving background methotrexate: a 5-year extended phase IIB study. Journal of Rheumatology 2009;36(4):736-42.

\section{Westhovens 2009b}

Westhovens R, Robles M, Ximenes AC, Nayiager S, Wollenhaupt J, Durez P, et al. Clinical efficacy and safety of abatacept in methotrexate-naive patients with early rheumatoid arthritis and poor prognostic factors. Annals of the Rheumatic Diseases 2009;68(12):1870-7. 


\section{Wiedenmann 2008}

Wiedenmann B, Malfertheiner P, Friess H, Ritch P, Arseneau J, Mantovani G, et al. A multicenter, phase II study of infliximab plus gemcitabine in pancreatic cancer cachexia. Journal of Supportive Oncology 2008;6(1):18-25.

\section{Witzig 2002}

Witzig TE, Gordon LI, Cabanillas F, Czuczman MS, Emmanouilides C, Joyce R, et al. Randomized controlled trial of yttrium-90-labeled ibritumomab tiuxetan radioimmunotherapy versus rituximab immunotherapy for patients with relapsed or refractory low-grade, follicular, or transformed B-cell non-Hodgkin's lymphoma. Journal of Clinical Oncology 2002;20(10):2453-63.

\section{Zein 2005}

Zein NN, Etanercept Study Group. Etanercept as an adjuvant to interferon and ribavirin in treatment-naive patients with chronic hepatitis $C$ virus infection: a phase 2 randomized, double-blind, placebo-controlled study. Journal of Hepatology 2005;42(3):315-22.

\section{Zhou 2007}

Zhou H, Jang H, Fleischmann RM, Bouman-Thio E, Xu Z, Marini JC, et al. Pharmacokinetics and safety of golimumab, a fully human anti-TNF-alpha monoclonal antibody, in subjects with rheumatoid arthritis. Journal of Clinical Pharmacology 2007;47(3):383-96

\section{References to excluded reviews}

\section{Ansell 2006}

Ansell SM, Geyer SM, Maurer MJ, Kurtin PJ, Micallef INM, Stella P, et al. Randomized phase II study of interleukin-12 in combination with rituximab in previously treated nonHodgkin's lymphoma patients. Clinical Cancer Research 2006;12(20 Pt 1):6056-63.

\section{Bathon 2006}

Bathon JM, Fleischmann RM, Van der Heijde D, Tesser JR, Peloso PM, Chon Y, et al. Safety and efficacy of etanercept treatment in elderly subjects with rheumatoid arthritis. Journal of Rheumatology 2006;33(2):234-43.

\section{Bienvenu 2001}

Bienvenu J, Chvetzoff R, Salles G, Balter C, Tilly H, Herbrecht R, et al. Tumor necrosis factor alpha release is a major biological event associated with rituximab treatment. The Hematology Journal : the official journal of the European Hematology Association / EHA 2001;2(6):378-84.

\section{Boehme 2009}

Boehme V, Schmitz N, Zeynalova S, Loeffler M, Pfreundschuh M. CNS events in elderly patients with aggressive lymphoma treated with modern chemotherapy (CHOP-14) with or without rituximab: an analysis of patients treated in the RICOVER-60 trial of the German High-Grade Non-Hodgkin Lymphoma Study Group (DSHNHL). Blood 2009;113(17):3896-902.

\section{Cohen 2007}

Cohen SP, Wenzell D, Hurley RW, Kurihara C, Buckenmaier CC 3rd, Griffith S, et al. A double-blind, placebocontrolled, dose-response pilot study evaluating intradiscal etanercept in patients with chronic discogenic low back pain or lumbosacral radiculopathy. Anesthesiology 2007;107(1):99-105.

\section{Cohen 2009}

Cohen S P, Bogduk N, Dragovich A, Buckenmaier C C, Griffith S, Kurihara $C$, et al. Randomized, double-blind, placebocontrolled, dose-response, and preclinical safety study of transforaminal epidural etanercept for the treatment of sciatica. Anesthesiology 2009;110(5):1116-26.

\section{Combe 2006}

Combe B, Codreanu C, Fiocco U, Gaubitz M, Geusens PP Kvien TK, et al. Etanercept and sulfasalazine, alone and combined, in patients with active rheumatoid arthritis despite receiving sulfasalazine: a double-blind comparison. Annals of the Rheumatic Diseases 2006;65:1357-62.

\section{D'Haens 2008}

D'Haens G, Baert F, van Assche G, Caenepeel P, Vergauwe P, Tuynman $\mathrm{H}$, et al. Early combined immunosuppression or conventional management in patients with newly diagnosed Crohn's disease: an open randomised trial. Lancet 2008;371:660-7.

\section{De Vos 2009}

De Vos S, Goy A, Dakhil SR, Saleh MN, McLaughlin P, Belt R, et al. Multicenter randomized phase II study of weekly or twiceweekly bortezomib plus rituximab in patients with relapsed or refractory follicular or marginal-zone B-cell lymphoma. Journal of Clinical Oncology 2009;27(30):5023-30.

\section{Erin 2006}

Erin EM, Leaker BR, Nicholson GC, Tan AJ, Green LM, Neighbour $\mathrm{H}$, et al. The effects of a monoclonal antibody directed against tumor necrosis factor-alpha in asthma. American Journal of Respiratory and Critical Care Medicine 2006;174:753-62.

\section{Feist 2009}

Feist E, Burmester GR. Is tocilizumab in combination with traditional DMARDs safe and effective for patients with active RA?. Nature Clinical Practice Rheumatology 2009;5:128-9.

\section{Fernandez-Lopez 2006}

Fernandez-Lopez C, Blanco FJ. ATTAIN study: Efficacy of abatacept in patients with rheumatoid arthritis and inadequate response to anti-TNF-alpha. [Spanish]. Reumatologia Clinica Suplementos 2006;1:34-43.

\section{Genovese 2004}

Genovese MC, Cohen S, Moreland L, Lium D, Robbins S, Newmark R, et al. Combination therapy with etanercept and anakinra in the treatment of patients with rheumatoid arthritis who have been treated unsuccessfully with methotrexate. Arthritis and Rheumatism 2004;50(5):1412-9. 


\section{Goekoop-Ruiterman 2005}

Goekoop-Ruiterman YPM, De Vries-Bouwstra JK, Allaart CF, Van Zeben D, Kerstens PJSM, Hazes JMW, et al. Clinical and radiographic outcomes of four different treatment strategies in patients with early rheumatoid arthritis (the BeSt study): a randomized, controlled trial. Arthritis and Rheumatism 2005;52:3381-90.

\section{Goekoop-Ruiterman 2007}

Goekoop-Ruiterman YPM, De Vries-Bouwstra JK, Allaart CF, Van Zeben D, Kerstens PJSM, Hazes JMW, et al. Comparison of treatment strategies in early rheumatoid arthritis: a randomized trial. Annals of Internal Medicine: 2007;146:406-15.

\section{Gottlieb 2006}

Gottlieb AB, Kircik L, Eisen D, Jackson JM, Boh EE, Strober BE, et al. Use of etanercept for psoriatic arthritis in the dermatology clinic: The Experience Diagnosing, Understanding Care, and Treatment with Etanercept (EDUCATE) study. Journal of Dermatological Treatment 2006;17:343-52.

\section{Griffiths 2010}

Griffiths CE, Strober BE, Van de Kerkhof P, Ho V, Fidelus-Gort R, Yeilding $\mathrm{N}$, et al. Comparison of ustekinumab and etanercept for moderate-to-severe psoriasis. New England Journal of Medicine 2010;362:118-28.

\section{Kaplan 2005}

Kaplan LD, Lee JY, Ambinder RF, Sparano JA, Cesarman E, Chadburn A, et al. Rituximab does not improve clinical outcome in a randomized phase 3 trial of CHOP with or without rituximab in patients with HIV-associated non-Hodgkin lymphoma: AIDSMalignancies Consortium Trial 010. Blood 2005;106:1538-43.

\section{Kimby 2008}

Kimby E, Jurlander J, Geisler C, Hagberg H, Holte H, Lehtinen T, et al. Long-term molecular remissions in patients with indolent lymphoma treated with rituximab as a single agent or in combination with interferon alpha-2a: a randomized phase II study from the Nordic Lymphoma Group. Leukemia and Lymphoma 2008;49:102-12.

\section{Kremer 2008}

Kremer JM, Genant HK, Moreland LW, Russell AS, Emery P, Abud-Mendoza C, et al. Results of a two-year followup study of patients with rheumatoid arthritis who received a combination of abatacept and methotrexate. Arthritis and Rheumatism 2008;58:953-63.

\section{Lee 2009}

Lee RA, Dommasch E, Treat J, Sciacca-Kirby J, Chachkin S, Williams J, et al. A prospective clinical trial of open-label etanercept for the treatment of hidradenitis suppurativa. Journal of the American Academy of Dermatology 2009;60(4):565-73.

\section{Li 2008}

Li EK, Griffith JF, Lee VW, Wang YX, Li TK, Lee KK, et al. Shortterm efficacy of combination methotrexate and infliximab in patients with ankylosing spondylitis: a clinical and magnetic resonance imaging correlation. Rheumatology 2008;47:1358-63.

\section{Maini 2004}

Maini RN, Breedveld FC, Kalden JR, Smolen JS, Furst D, Weisman $\mathrm{MH}$, et al. Sustained improvement over two years in physical function, structural damage, and signs and symptoms among patients with rheumatoid arthritis treated with infliximab and methotrexate. Arthritis and Rheumatism 2004;50(4):1051-65.

\section{Moore 2007}

Moore A, Gordon KB, Kang S, Gottlieb A, Freundlich B, Xia HA, et al. A randomized, open-label trial of continuous versus interrupted etanercept therapy in the treatment of psoriasis. Journal of the American Academy of Dermatology 2007;56(4):598-603.

\section{Moreland 2006}

Moreland LW, Weinblatt ME, Keystone EC, Kremer JM, Martin RW, Schiff MH, et al. Etanercept treatment in adults with established rheumatoid arthritis: 7 years of clinical experience. Journal of Rheumatology 2006;33(5):854-61.

\section{Nikas 2006}

Nikas SN, Voulgari PV, Alamanos Y, Papadopoulos CG, Venetsanopoulou Al, Georgiadis AN, et al. Efficacy and safety of switching from infliximab to adalimumab: a comparative controlled study. Annals of the Rheumatic Diseases 2006;65(2):257-60.

\section{Ogura 2006}

Ogura M, Morishima Y, Kagami Y, Watanabe T, Itoh K, Igarashi T, et al. Randomized phase II study of concurrent and sequential rituximab and $\mathrm{CHOP}$ chemotherapy in untreated indolent B-cell lymphoma. Cancer Science 2006;97(4):305-12.

\section{Ramos-Remus 2008}

Ramos-Remus C, Muriel-Vizcaino R. The OPTION trial: Inhibition of the interleukin-6 receptor with tocilizumab in patients with rheumatoid arthritis http:// dx.doi.org/10.2217/17460816.3.5.429. Future Rheumatology 2008;3(5):429-34.

\section{Ribrag 2009}

Ribrag V, Gisselbrecht C, Haioun C, Salles G, Golfier JB, Ertault $\mathrm{M}$, et al. Efficacy and toxicity of 2 schedules of frontline rituximab plus cyclophosphamide, doxorubicin, vincristine, and prednisone plus bortezomib in patients with B-cell lymphoma: a randomized phase 2 trial from the French Adult Lymphoma Study Group (GELA). Cancer 2009;115(19):4540-6.

\section{Rutgeerts 2004}

Rutgeerts P, Feagan BG, Lichtenstein GR, Mayer LF, Schreiber S, Colombel JF, et al. Comparison of scheduled and episodic treatment strategies of infliximab in Crohn's disease. Gastroenterology 2004;126(2):402-13.

\section{Saurat 2008}

Saurat JH, Stingl G, Dubertret L, Papp K, Langley RG, Ortonne JP, et al. Efficacy and safety results from the randomized controlled comparative study of adalimumab vs. methotrexate vs. placebo in patients with psoriasis (CHAMPION). British Journal of Dermatology 2008;158(3):558-66. 


\section{Schroder 2006}

Schroder O, Blumenstein I, Stein J. Combining infliximab with methotrexate for the induction and maintenance of remission in refractory Crohn's disease: a controlled pilot study. European Journal of Gastroenterology and Hepatology 2006;18(1):11-6.

\section{Sibilia 2007}

Sibilia J, Westhovens R. Safety of T-cell co-stimulation modulation with abatacept in patients with rheumatoid arthritis. Clinical and Experimental Rheumatology 2007;25 Suppl(5):46-56.

\section{Soubrier 2009}

Soubrier M, Puechal X, Sibilia J, Mariette X, Meyer O, Combe B, et al. Evaluation of two strategies (initial methotrexate monotherapy vs its combination with adalimumab) in management of early active rheumatoid arthritis: data from the GUEPARD trial. Rheumatology 2009;48(11):1429-34.

\section{Tesser 2004}

Tesser J, Fleischmann R, Dore R, Bennett R, Solinger A, Joh T, et al. Concomitant medication use in a large, international, multicenter, placebo controlled trial of anakinra, a recombinant interleukin 1 receptor antagonist, in patients with rheumatoid arthritis. Journal of Rheumatology 2004;31(4):649-54.

\section{Tornero 2006}

Tornero Molina J. The AIM study: Efficacy of abatacept in patients with rheumatoid arthritis and inadequate response to methotrexate. [Spanish]. Reumatologia Clinica Suplementos 2006;1(2):25-33.

\section{Tyring 2006}

Tyring S, Gottlieb A, Papp K, Gordon K, Leonardi C, Wang A, et al. Etanercept and clinical outcomes, fatigue, and depression in psoriasis: double-blind placebo-controlled randomised phase III trial. Lancet 2006;367(9504):29-35.

\section{Van der Heijde 2006c}

Van der Heijde D, Klareskog L, Rodriguez-Valverde V, Codreanu C, Bolosiu H, Melo-Gomes J, et al. Comparison of etanercept and methotrexate, alone and combined, in the treatment of rheumatoid arthritis: two-year clinical and radiographic results from the TEMPO study, a double-blind, randomized trial. Arthritis and Rheumatism 2006;54(4):1063-74.

\section{Van der Heijde 2008b}

Van der Heijde D, Pangan AL, Schiff MH, Braun J, Borofsky M, Torre J, et al. Adalimumab effectively reduces the signs and symptoms of active ankylosing spondylitis in patients with total spinal ankylosis. Annals of the Rheumatic Diseases 2008;67(9):1218-21.

\section{Van Heeckeren 2006}

Van Heeckeren WJ, Vollweiler J, Fu P, Cooper BW, Meyerson H, Lazarus HM, et al. Randomised comparison of two B-cell purging protocols for patients with B-cell non-Hodgkin lymphoma: in vivo purging with rituximab versus ex vivo purging with CliniMACS CD34 cell enrichment device. British Journal of Haematology 2006;132(1):42-55.

\section{Van Riel 2006}

Van Riel PLCM, Taggart AJ, Sany J, Gaubitz M, Nab HW, Pedersen R, et al. Efficacy and safety of combination etanercept and methotrexate versus etanercept alone in patients with rheumatoid arthritis with an inadequate response to methotrexate: the ADORE study. Annals of the Rheumatic Diseases 2006;65(11):1478-83.

\section{Xu 2008}

Xu W, Li JY, Zhang ZH, Qiu HX, Qian SX, Wu HX, et al. Comparison between efficacy and safety of rituximab plus $\mathrm{CHOP}$ regimen and $\mathrm{CHOP}$ regimen for treatment of newly diagnosed patients with diffuse large B-cell lymphoma. [Chinese]. Journal of Experimental Hematology / Chinese Associationo of Pathhophysiology 2008;16(4):933-7.

\section{Zachariae 2008}

Zachariae C, Mork N-J, Reunala T, Lorentzen H, Falk E, Karvonen S-L, et al. The combination of etanercept and methotrexate increases the effectiveness of treatment in active psoriasis despite inadequate effect of methotrexate therapy. Acta Dermato-Venereologica 2008;88(5):495-501.

\section{Additional references}

\section{Alonso-Ruiz 2008}

Alonso-Ruiz A, Pijoan JI, Ansuategui E, Urkaregi A, Calabozo M, Quintana A. Tumor necrosis factor alpha drugs in rheumatoid arthritis: systematic review and metaanalysis of efficacy and safety. BMC Musculoskeletal Disorders 2008;9(52):1-27.

\section{Becker 2008}

Becker LA, Oxman AD. Chapter 22: Overviews of Reviews. In: Higgins JP, Green S, editors, Cochrane Handbook for Systematic Reviews of Interventions Version 5.0.1 (updated September 2008). The Cochrane Collaboration, 2008. Available from www.cochranehandbook.org.

\section{Behm 2008}

Behm BW, Bickston SJ. Tumor necrosis factor-alpha antibody for maintenance of remission in Crohn's disease. Cochrane Database of Systematic Reviews 2008, Issue 1. [DOI: 10.1002/14651858.CD006893]

\section{Blumenauer 2002}

Blumenauer BBTB, Judd M, Wells GA, Burls A, Cranney A, Hochberg MC, et al. Infliximab for the treatment of rheumatoid arthritis. Cochrane Database of Systematic Reviews 2002, Issue 3. [DOI: 10.1002/14651858.CD003785]

\section{Blumenauer 2003}

Blumenauer BBTB, Cranney A, Burls A, Coyle D, Hochberg MC, Tugwell $P$, et al. Etanercept for the treatment of rheumatoid arthritis. Cochrane Database of Systematic Reviews 2003, Issue 3. [DOI: 10.1002/14651858.CD004525]

\section{Bongartz 2006}

Bongartz T, Sutton AJ, Sweeting MJ, Buchan I, Matteson EL, Montori V. Anti-TNF antibody therapy in rheumatoid arthritis and the risk of serious infections and malignancies: systematic 
review and meta-analysis of rare harmful effects in randomized controlled trials. JAMA 2006 May 17;295(19):2275-85.

\section{Doherty 2009}

Doherty G, Bennett G, Patil S, Cheifetz A, Moss AC. Interventions for prevention of post-operative recurrence of Crohn's disease. Cochrane Database of Systematic Reviews 2009, Issue 4. [DOI: 10.1002/14651858.CD006873.pub2]

\section{Drugs.com 2006}

Drug Information Online. Drugs.com. FDA Approves First Rheumatoid Arthritis Indication for Rituxan. http:// www.drugs.com/news/fda-approves-first-rheumatoid-arthritisindication-rituxan-1745.html 03/01/2006.

\section{FDA 1998a}

Food, Drug Administration. Etanercept Product Approval Information- Licensing Action 12/2/1998. http:// www.fda.gov/Drugs/DevelopmentApprovalProcess/ HowDrugsareDevelopedandApproved/ApprovalApplications/ TherapeuticBiologicApplications/ucm080536.htm 1998.

\section{FDA 1998b}

Food, Drug Administration. Medication Guide: Enbrel $^{\circledR}$ (etanercept). http://www.accessdata.fda.gov/drugsatfda_docs/ label/2008/103795s5359lbl.pdf.

\section{FDA 1999}

Food, Drug Administration. Remicade ${ }^{\circledast}$ (infliximab) for IV Injection. http://www.fda.gov/ downloads/Drugs/DevelopmentApprovalProcess/ HowDrugsareDevelopedandApproved/ApprovalApplications/ TherapeuticBiologicApplications/ucm107722.pdf 1999.

\section{FDA 2001}

Food, Drug Administration. Kineret ${ }^{\circledR}$ (anakinra) Physician packet insert: Kineret ${ }^{\circledR}$ (anakinra) prescribing information. http://www.fda.gov/Drugs/DevelopmentApprovalProcess/ HowDrugsareDevelopedandApproved/ApprovalApplications/ TherapeuticBiologicApplications/ucm080650.htm 2001.

\section{FDA 2002a}

Food, Drug Administration. Humira ${ }^{\circledR}$ (adalimumab): Highlights of prescribing information. http://www.accessdata.fda.gov/ drugsatfda_docs/label/2008/125057s114lbl.pdf.

\section{FDA 2002b}

Food, Drug Administration. Package Insert. HUMIRA ${ }^{\circledR}$ (adalimumab). Abbott Laboratories. http:// www.fda.gov/Drugs/DevelopmentApprovalProcess/ HowDrugsareDevelopedandApproved/ApprovalApplications/ TherapeuticBiologicApplications/ucm080610.htm 2002.

\section{FDA 2005}

Food, Drug Administration. Patient Information Sheet. Abatacept (marketed as Orencia ${ }^{\circledR}$ ). http:// www.fda.gov/Drugs/DevelopmentApprovalProcess/ HowDrugsareDevelopedandApproved/ DrugandBiologicApprovalReports/FastTrackApprovalReports/ ucm082380.htm 2005.

\section{FDA 2006}

Food, Drug Administration. Rituxan ${ }^{\circledast}$ (rituximab). http:// www.fda.gov/Safety/MedWatch/Safetylnformation/ SafetyAlertsforHumanMedicalProducts/ucm150747.htm.

\section{FDA 2009a}

FDA: FDA Center for Drug Evaluation and Research. SIMPONI ${ }^{\circledR}$ (Golimumab) Summary Review. http:// www.accessdata.fda.gov/drugsatdfa_docs/ nda/2009/125289s000_SumR.pdf 2009.

\section{FDA 2009b}

FDA. SIMPONI ${ }^{\circledR}$ (Golimumab) Physician Packet Insert: Highlights of Prescribing Information. http://www.accessdata.fda.gov/ drugsatdfa_docs/label/2009/125289s000lbl.pdf 2009.

\section{FDA 2009c}

Food, Drug Administration. Cimzia ${ }^{\circledR}$ (Certolizumab): Highlights of prescribing information. http://www.accessdata.fda.gov/ drugsatfda_docs/label/2009/125160s092lbl.pdf 2009.

\section{FDA 2009d}

Food, Drug Administration. Drug details: Orencia ${ }^{\circledR}$. http://www.accessdata.fda.gov/drugsatfda_docs/ label/2009/125118s0086lbl.pdf 2009.

\section{FDA 2009e}

Food, Drug Administration. Remicade ${ }^{\circledR}$ (infliximab) for IV Injection. http://www.accessdata.fda.gov/drugsatfda_docs/ label/2009/103772s5234lbl.pdf 2009.

\section{FDA 2010}

FDA: Food, Drug Administration. Medication Guide. Actermra (Tocilizumab). http://www.fda.gov/downloads/Drugs/ DrugSafety/UCM197463.pdf 2010.

\section{FDA 2010b}

Food and Drug Administration. Department of Health and Human Services: Safety. MedWatch: The FDA Safety information and adverse event reporting program: Reporting serious problems to FDA: What is a serious advent event?. http:// www.fda.gov/safety/medwatch/howtoreport/ucm053087.htm. Page last udpated 12/15/2010.

\section{Golicki 2009}

Golicki D, Macioch T, Niewada M, Jakubczyk M, Tlustochowicz M, Owczarek W, Tlustochowicz W. TNF-alpha inhibitors for psoriatic arthritis. Cochrane Database of Systematic Reviews 2009, Issue 3. [DOI: 10.1002/14651858.CD007940]

\section{Guyatt 2011}

Guyatt G, Oxman AD, Kunz R, Brozek J, Alonso-Coello P, Rind D, et al. GRADE guidelines 6 . Rating the quality of evidenceimprecision. Journal of Clinical Epidemiology 2011;64:1283-93.

\section{Harris 1990}

Harris ED Jr. Rheumatoid arthritis. Pathophysiology and implications for therapy. New England Journal of Medicine 1990;322(18):1277-89. 


\section{Higgins 2011}

Higgins JPT, Green S, editors. Cochrane Handbook for Systematic Reviews of Interventions Version 5.1.0 [updated March 2011]. The Cochrane Collaboration, 2011. Available from www.cochrane-handbook.org.

\section{Keystone 2009b}

Keystone E. Recent concepts in the inhibition of radiographic progression with biologics. Current Opinion in Rheumatology 2009;21(3):231-7.

\section{Kvien 2004}

Kvien TK. Epidemiology and burden of illness of rheumatoid arthritis. Pharmacoeconomics 2004;22 Suppl 1(2):1-12.

\section{Kvien 2005}

Kvien TK, Uhlig T. Quality of life in rheumatoid arthritis. Scandinavian Journal of Rheumatology 2005;34(5):333-41.

\section{Lee 2008}

Lee YH, Woo JH, Rho YH, Choi SJ, Ji JD, Song GG. Meta-analysis of the combination of TNF inhibitors plus MTX compared to MTX monotherapy, and the adjusted indirect comparison of TNF inhibitors in patients suffering from active rheumatoid arthritis. Rheumatology International 2008 April;28(6):553-9.

\section{Lubeck 2004}

Lubeck DP. Patient-reported outcomes and their role in the assessment of rheumatoid arthritis. Pharmacoeconomics 2004;22 Suppl 1(2):27-38

\section{Maxwell 2009}

Maxwell L, Singh JA. Abatacept for rheumatoid arthritis. Cochrane Database of Systematic Reviews 2009, Issue 4. [DOI: 10.1002/14651858.CD007277]

\section{Menge 2008}

Menge T, et al. Disease-modifying agents for multiple sclerosis: recent advances and future prospects. Drugs 2008;68(17):2445-68.

\section{Mertens 2009}

Mertens M, Singh JA. Anakinra for rheumatoid arthritis. Cochrane Database of Systematic Reviews 2009, Issue 1. [DOI: 10.1002/14651858.CD005121]

\section{Navarro-Sarabia 2005}

Navarro-Sarabia F, Ariza-Ariza R, Hernandez-Cruz B, Villanueva I. Adalimumab for treating rheumatoid arthritis. Cochrane Database of Systematic Reviews 2005, Issue 3. [DOI: 10.1002/14651858.CD005113.pub2]

\section{Ntzoufras 2008}

Ntzoufras I. Wiley Series in Computational Statistics, in Bayesian Modeling Using WinBUGS. Hoboken, NJ, USA: John Wiley \& Sons, Inc., 2008. [DOI: 10.1002/9780470434567.scard]

\section{Odegard 2005}

Odegard S, Finset A, Kvien TK, Mowinckel P, Uhlig T. Work disability in rheumatoid arthritis is predicted by physical and psychological health status: a 7-year study from the
Oslo RA register. Scandinavian Journal of Rheumatology 2005;34(6):441-7.

\section{Pincus 1983}

Pincus T, Summey JA, Soraci SA, Jr, Wallston KA, Hummon NP. Assessment of patient satisfaction in activities of daily living using a modified Stanford Health Assessment Questionnaire. Arthritis and Rheumatism 1983;26(11):1346-53.

\section{Pogue 1997}

Pogue JM, Yusuf S. Cumulating evidence from randomized trials: utilizing sequential monitoring boundaries for cumulative meta-analysis. Controlled Clinical Trials 1997 Dec;18(6):580-93.

\section{Rozenblit 2009}

Rozenblit M, Lebwohl M. New biologics for psoriasis and psoriatic arthritis. Dermatologic Therapy 2009;22(1):56-60.

\section{Ruiz Garcia 2011}

Ruiz Garcia V, Jobanputra P, Burls A, Cabello JB, Gálvez Muñoz JG, Saiz Cuenca ESC, Fry-Smith A. Certolizumab pegol (CDP870) for rheumatoid arthritis in adults. Cochrane Database of Systematic Reviews 2011, Issue 2. [DOI: 10.1002/14651858.CD007649.pub2]

\section{Schulz 2007}

Schulz H, Bohlius J, Skoetz N, Trelle S, Kober T, Reiser M, et al. Chemotherapy plus Rituximab versus chemotherapy alone for B-cell non-Hodgkin's lymphoma. Cochrane Database of Systematic Reviews 2007, Issue 4. [DOI: 10.1002/14651858.CD003805.pub2]

\section{Schünemann 2008a}

Schünemann HJ, Oxman AD, Higgins JPT, Vist GE, Glasziou P, Guyatt GH. Chapter 11: Presenting results and 'Summary of findings' tables. In: Higgins JPT, Green S (editors), Cochrane Handbook for Systematic Reviews of Interventions Version 5.0.1 (updated September 2008). The Cochrane Collaboration, 2008. Available from www.cochrane-handbook.org.

\section{Schünemann 2008b}

Schünemann HJ, Oxman AD, Vist GE, Higgins JPT, Deeks JJ, Glasziou P, Guyatt GH. Chapter 12: Interpreting results and drawing conclusions. In: Higgins JPT, Green S (editors), Cochrane Handbook for Systematic Reviews of Interventions Version 5.0.1 (updated September 2008). The Cochrane Collaboration, 2008. Available from www.cochranehandbook.org.

\section{Scott 2006}

Scott DL, Kingsley GH. Tumor necrosis factor inhibitors for rheumatoid arthritis. New England Journal of Medicine 2006;355(7):704-12.

\section{Singh 2009a}

Singh JA, Christensen R, Wells GA, Suarez-Almazor ME, Buchbinder R, Lopez-Olivo MA, et al. Biologics for rheumatoid arthritis: an overview of Cochrane reviews. Cochrane Database of Systematic Reviews 2009, Issue 4. [DOI: 10.1002/14651858.CD007848.pub2] 


\section{Singh 2009b}

Singh JA, Christensen R, Wells GA, Suarez-Almazor ME, Buchbinder R, Lopez-Olivo MA, et al. A network meta-analysis of randomized controlled trials of biologics for rheumatoid arthritis: a Cochrane overview. Canadian Medical Association Journal 2009;181(11):787-96.

\section{Singh 2010a}

Singh JA, Beg S, Lopez-Olivo MA. Tocilizumab for rheumatoid arthritis. Cochrane Database of Systematic Reviews 2010, Issue 7. [DOI: 10.1002/14651858.CD008331]

\section{Singh 2010b}

Singh JA, Noorbaloochi S, Singh G. Golimumab for rheumatoid arthritis. Cochrane Database of Systematic Reviews 2010, Issue 1. [DOI: 10.1002/14651858.CD008341]

\section{Spiegelhalter 2003}

Spiegelhalter D, Thomas A, Best N, Lunn D. WinBUGS user manual. Version 1.4. [Cambridge, UK]: BUGS Project; http:// www.mrc-bsu.cam.ac.uk/bugs/winbugs/manual14.pdf 2003 Jan.

\section{Strand 2008}

Strand V, Singh JA. Improved health-related quality of life with effective disease-modifying antirheumatic drugs: evidence from randomized controlled trials. American Journal of Managed Care 2008;14(4):234-54.

\section{Strand 2010}

Strand V, Singh JA. Newer biological agents in rheumatoid arthritis: impact on health-related quality of life and productivity. Drugs. 2010;70(2):121-45.

\section{Vidal 2009}

Vidal L, Gafter-Gvili A, Leibovici L, Shpilberg O. Rituximab as maintenance therapy for patients with follicular lymphoma. Cochrane Database of Systematic Reviews 2009, Issue 2. [DOI: 10.1002/14651858.CD006552.pub2]

\section{Wiens 2010}

Wiens A, Venson R, Correr CJ, Otuki MF, Pontarolo R. Metaanalysis of the efficacy and safety of adalimumab, etanercept, and infliximab for the treatment of rheumatoid arthritis. Pharmacotherapy 2010 April;30(4):339-53.

\section{Yelin 2007}

Yelin E. Work disability in rheumatic diseases. Current Opinion in Rheumatology 2007;19(2):91-6.

\section{Zochling $\mathbf{J}$}

Zochling J, Maxwell L, Beardmore J, Boonen A. TNFalpha inhibitors for ankylosing spondylitis. Cochrane Database of Systematic Reviews 2009, Issue 1. [DOI: 10.1002/14651858.CD005468]

\section{ADDITIONAL TABLES}

Table 1. Details on doses used for the dose-adjusted analysis

\begin{tabular}{lll}
\hline & Approved dose and range & Dose used for adjustment \\
\hline Etanercept & $25 \mathrm{mg}$ SQ twice a week & $50 \mathrm{mg}$ qweek \\
\hline Infliximab & $3-5 \mathrm{mg} / \mathrm{kg}$ Q8 weeks; may increase to $10 \mathrm{mg} / \mathrm{kg}$ & $3 \mathrm{mg} / \mathrm{kg}$ q8weeks \\
\hline Adalimumab & $40 \mathrm{mg}$ SQ Q2 weeks & $40 \mathrm{mg}$ q2weeks \\
\hline Golimumab & $50 \mathrm{mg}$ SQ Q4 weeks & $50 \mathrm{mg}$ q4weeks \\
\hline Certolizumab pegol & $400 \mathrm{mg}$ SQ initially, then 200-mg Qother week or $400 \mathrm{mg}$ monthly & $400 \mathrm{mg}$ monthly \\
\hline Anakinra & $100 \mathrm{mg}$ SQ Qday & $100 \mathrm{mg}$ qday \\
\hline Rituximab & 500 or 1000 mg -2 infusions, 2 weeks apart & $500-1000$ mg 2wks apart \\
\hline Abatacept & 500,750 or 1000 mg Q4 weeks & $500-1000$ mg Q4weeks
\end{tabular}


Table 2. Summary of characteristics of included studies

\begin{tabular}{|c|c|c|}
\hline Characteristic & $\begin{array}{l}\text { Randomized-con- } \\
\text { trolled trials, } \\
\mathrm{N}=160\end{array}$ & $\begin{array}{l}\text { Open-label exten- } \\
\text { sion studies, } N=46\end{array}$ \\
\hline \multicolumn{3}{|l|}{ Type of intervention } \\
\hline abatacept & 7 & 2 \\
\hline adalimumab & 22 & 10 \\
\hline anakinra & 5 & 2 \\
\hline certolizumab pegol & 6 & 1 \\
\hline etanercept & 39 & 10 \\
\hline golimumab & 8 & 1 \\
\hline infliximab & $40^{\star \star \star}$ & 18 \\
\hline rituximab & 29 & 1 \\
\hline tocilizumab & 5 & 1 \\
\hline \multicolumn{3}{|l|}{ Type of condition } \\
\hline rheumatoid arthritis & 62 & 18 \\
\hline cancer & 25 & 0 \\
\hline psoriasis & 14 & 8 \\
\hline IBD & 12 & 1 \\
\hline ankylosing spondylitis & 10 & 10 \\
\hline psoriatic arthritis & 7 & 7 \\
\hline Crohn's disease & 6 & 0 \\
\hline ulcerative colitis & 6 & 0 \\
\hline other* & 18 & 2 \\
\hline Trial duration, months mean(SD; median) & $9.8(11.5 ; 6.0)$ & $20.7(17.9 ; 13.5)$ \\
\hline Trial duration, short $<6$ months, $N$ studies & 98 & 9 \\
\hline Trial duration: intermediate $(6<\mathrm{mo} . \leq 12), \mathrm{N}$ studies & 27 & 12 \\
\hline Trial duration: long $>12$ months , $N$ studies & 35 & 25 \\
\hline Age, years mean(SD; median) & $49.9(8.2 ; 51)$ & $79.9(24.2 ; 87.0)$ \\
\hline \% Female mean(SD; median) & $58.9(20.4 ; 61)$ & $57.3(24.5 ; 61.7)$ \\
\hline
\end{tabular}


Table 2. Summary of characteristics of included studies (Continued)

IBD = inflammatory bowel disease; SD = standard deviation; *other conditions for RCT include: heart failure, multiple sclerosis, COPD, alcoholic hepatitis, diabetes, lupus, active spondylarthropathy, osteoarthritis, asthma, cardiac or renal transplantation, Sjogren's syndrome, polymyalgia rheumatica, autoimmune inner ear disease, giant cell arteritis, pulmonary sarcoidosis, Hepatitis C, cancer anorexia/weight loss syndrome, Wegener's granulomatosis; other conditions for OLE = sarcoidosis, axial spondylarthritis; ${ }^{\star \star \star}$ one study (Schiff 2008) had two treatment arms (abatacept and infliximab)

Table 3. Summary of findings table 1

Biologics for any condition except HIV/AIDS: standard drug dose* and control event rate

\begin{tabular}{|c|c|c|c|c|c|c|}
\hline \multirow[t]{3}{*}{ Outcome } & $\begin{array}{l}\text { Comparison } \\
\text { intervention }\end{array}$ & $\begin{array}{l}\text { Illustrative comparative } \\
\text { risks }\end{array}$ & \multirow[t]{3}{*}{$\begin{array}{l}\text { Relative effect } \\
(95 \% \mathrm{Cl})\end{array}$} & \multirow{3}{*}{$\begin{array}{l}\text { Number of par- } \\
\text { ticipants } \\
\text { (studies) }\end{array}$} & \multirow{3}{*}{$\begin{array}{l}\text { Quality } \\
\text { of the ev- } \\
\text { idence } \\
\text { (GRADE) }\end{array}$} & \multirow[t]{3}{*}{ NNTH $(95 \% \mathrm{Cl})$} \\
\hline & $\begin{array}{l}\text { Assumed risk } \\
\text { with com- } \\
\text { parator }\end{array}$ & $\begin{array}{l}\text { Corresponding risk with } \\
\text { intervention }(95 \% \mathrm{Cl})\end{array}$ & & & & \\
\hline & Control & Biologics ** & & & & \\
\hline $\begin{array}{l}\text { Serious adverse } \\
\text { events }\end{array}$ & 118 per 1000 & $\begin{array}{l}127 \text { per } 1000 \text { (115 to } \\
142)\end{array}$ & $\begin{array}{l}\text { OR } 1.09 \text { (0.97 to } \\
1.24 \text { ) }\end{array}$ & $\begin{array}{l}21,152 \\
\text { (76 studies) }\end{array}$ & $\begin{array}{l}\oplus \oplus \oplus \ominus \\
\text { moder- } \\
\text { ate }{ }^{1}\end{array}$ & $\begin{array}{l}\text { Not statistically } \\
\text { significant }\end{array}$ \\
\hline $\begin{array}{l}\text { Total adverse } \\
\text { events }\end{array}$ & 724 per 1000 & $\begin{array}{l}770 \text { per } 1000 \text { ( } 741 \text { to } \\
797)\end{array}$ & $\begin{array}{l}\text { OR } 1.28 \text { (1.09 to } \\
1.50)\end{array}$ & $\begin{array}{l}14,959 \\
\text { (48 studies) }\end{array}$ & $\begin{array}{l}\oplus \oplus \oplus \oplus \\
\text { high }\end{array}$ & 22 (14 to 60$)$ \\
\hline $\begin{array}{l}\text { Withdrawals } \\
\text { due to adverse } \\
\text { events }\end{array}$ & 98 per 1000 & $\begin{array}{l}137 \text { per } 1000 \text { (115 to } \\
168)\end{array}$ & $\begin{array}{l}\text { OR } 1.47 \text { ( } 1.20 \text { to } \\
1.86)\end{array}$ & $\begin{array}{l}22,636 \\
\text { (83 studies) }\end{array}$ & $\begin{array}{l}\oplus \oplus \oplus \ominus \\
\text { moder- } \\
\text { ate }^{1}\end{array}$ & 26 (15 to 58$)$ \\
\hline $\begin{array}{l}\text { Serious infec- } \\
\text { tions }\end{array}$ & 26 per 1000 & 35 per 1000 ( 27 to 46$)$ & $\begin{array}{l}\text { OR } 1.37 \text { (1.04 to } \\
1.82)\end{array}$ & $\begin{array}{l}21,853 \\
\text { (70 studies) }\end{array}$ & $\begin{array}{l}\oplus \oplus \oplus \ominus \\
\text { moder- } \\
\text { ate }^{1}\end{array}$ & 108 (50 to 989 ) \\
\hline $\begin{array}{l}\text { Tuberculosis } \\
\text { reactivation }\end{array}$ & 4 per 10,000 & 20 per 10,000 & $\begin{array}{l}\text { OR } 4.68 \text { ( } 1.18 \text { to } \\
18.60)\end{array}$ & $\begin{array}{l}30,671 \\
\text { (71 studies) }\end{array}$ & $\begin{array}{l}\oplus \oplus \odot \ominus \\
\text { low }\end{array}$ & $\begin{array}{l}681(143 \text { to } \\
14706)\end{array}$ \\
\hline Lymphoma & 9 per 10000 & 1 per 1000 & $\begin{array}{l}\text { OR } 0.53 \text { ( } 0.17 \text { to } \\
1.66)\end{array}$ & $\begin{array}{l}21,260 \\
\text { (52 studies) }\end{array}$ & $\begin{array}{l}\oplus \oplus \odot \ominus \\
\text { low }\end{array}$ & $\begin{array}{l}\text { Not statistically } \\
\text { significant }\end{array}$ \\
\hline $\begin{array}{l}\text { Congestive } \\
\text { heart failure }\end{array}$ & 8 per 1000 & $\begin{array}{l}6 \text { per } 1000 \\
(1 \text { to } 21)\end{array}$ & $\begin{array}{l}\text { OR } 0.69 \text { ( } 0.18 \text { to } \\
2.69)\end{array}$ & $\begin{array}{l}8847 \\
\text { (24 studies) }\end{array}$ & $\begin{array}{l}\oplus \oplus \odot \ominus \\
\text { low } 4\end{array}$ & $\begin{array}{l}\text { Not statistically } \\
\text { significant }\end{array}$ \\
\hline
\end{tabular}

* = standard drug dose was used for serious adverse events, total adverse events, withdrawals due to adverse events and serious infectiosn only. All doses were combined for tuberculosis reactivation, lymphoma and congestive heart failure because of very limited data.

$\star \star=$ all nine biologics as a group

$95 \% \mathrm{Cl}=95 \%$ confidence interval or $95 \%$ credible interval; NNTH = Number needed to treat for harm; OR = odds ratio

Control event rates based on the number of events in the included studies. 
1 The $95 \%$ credible interval around the pooled effect includes both no effect and appreciable benefit or harm.

2 Out of 19 studies, two studies (Buske 2009; Eve 2009) had inadequate allocation concealment; four studies (Eve 2009; Forstpointner 2004; Hainsworth 2005; Herold 2007) reported no blinding of personnel, participants and outcome assessors; two studies (Buske 2009; Salles 2007) reported no blinding of personnel and participants only.

3 Out of 15 studies, two (Buske 2009; Hiddemann 2005) had inadequate allocation concealment; four studies (Coiffier 1998; Forspointner 2004; Hainsworth 2005; Hiddemann 2005) reported no blinding of personnel, participants and outcome assessors; two studies (Forstpointner 2002; Salles 2007) reported no blinding of personel and participants only.

4 Very few events. 


\begin{tabular}{|c|c|c|c|c|c|c|c|}
\hline \multicolumn{8}{|c|}{ Biologics for any condition except HIV/AIDS: standard drug dose* and control event rate } \\
\hline \multirow[t]{3}{*}{ Intervention } & \multirow{3}{*}{$\begin{array}{l}\text { Comparison } \\
\text { intervention }\end{array}$} & \multicolumn{2}{|c|}{ Illustrative comparative risks } & \multirow{3}{*}{$\begin{array}{l}\text { Relative effect } \\
(95 \% \mathrm{Cl})\end{array}$} & \multirow{3}{*}{$\begin{array}{l}\text { Number of partici- } \\
\text { pants } \\
\text { (studies) }\end{array}$} & \multirow{3}{*}{$\begin{array}{l}\text { Quality of } \\
\text { the evidence } \\
\text { (GRADE) }\end{array}$} & \multirow[t]{3}{*}{ NNTH $(95 \% \mathrm{Cl})$} \\
\hline & & $\begin{array}{l}\text { Assumed } \\
\text { risk with } \\
\text { comparator }\end{array}$ & $\begin{array}{l}\text { Corresponding risk with in- } \\
\text { tervention }(95 \% \mathrm{Cl})\end{array}$ & & & & \\
\hline & & Control & Biologic & & & & \\
\hline \multicolumn{8}{|c|}{ Serious adverse events } \\
\hline Abatacept & control & 118 per 1000 & 116 per 1000 ( 76 to 144$)$ & OR 0.89 (0.61 to 1.26$)$ & $\begin{array}{l}2052 \\
\text { (5 studies) }\end{array}$ & $\begin{array}{l}\oplus \oplus \oplus \oplus \\
\text { high }\end{array}$ & $\begin{array}{l}\text { Not statistically signif- } \\
\text { icant }\end{array}$ \\
\hline $\begin{array}{l}\text { Adalimum- } \\
\text { ab }\end{array}$ & control & 118 per 1000 & 114 per 1000 ( 90 to 145 ) & OR 0.96 (0.74 to 1.27$)$ & $\begin{array}{l}4662 \\
\text { (15 studies) }\end{array}$ & $\begin{array}{l}\oplus \oplus \oplus \ominus \\
\text { moderate } 1\end{array}$ & $\begin{array}{l}\text { Not statistically signif- } \\
\text { icant }\end{array}$ \\
\hline Anakinra & control & 118 per 1000 & 122 per 1000 ( 82 to 180$)$ & OR 1.04 (0.67 to 1.64$)$ & $\begin{array}{l}1900 \\
\text { (3 studies) }\end{array}$ & $\begin{array}{l}\oplus \oplus \oplus \oplus \\
\text { high }\end{array}$ & $\begin{array}{l}\text { Not statistically signif- } \\
\text { icant }\end{array}$ \\
\hline $\begin{array}{l}\text { Certolizum- } \\
\text { ab pegol }\end{array}$ & control & 118 per 1000 & 174 per 1000 (124 to 237$)$ & OR 1.57 (1.06 to 2.32 ) & $\begin{array}{l}2421 \\
\text { (6 studies) }\end{array}$ & $\begin{array}{l}\oplus \oplus \oplus \odot \\
\text { moderate }^{1}\end{array}$ & 18 (9 to 162 ) \\
\hline Etanercept & control & 118 per 1000 & 142 per 1000 (111 to 184$)$ & OR 1.24 (0.93 to 1.69 ) & $\begin{array}{l}3931 \\
\text { (21 studies) }\end{array}$ & $\begin{array}{l}\oplus \oplus \oplus \ominus \\
\text { moderate } 1\end{array}$ & $\begin{array}{l}\text { Not statistically signif- } \\
\text { icant }\end{array}$ \\
\hline Golimumab & control & 118 per 1000 & 123 per 1000 ( 82 to 184$)$ & OR 1.05 (0.67 to 1.69 ) & $\begin{array}{l}1564 \\
\text { (8 studies) }\end{array}$ & $\begin{array}{l}\oplus \oplus \oplus \ominus \\
\text { moderate } 1\end{array}$ & $\begin{array}{l}\text { Not statistically signif- } \\
\text { icant }\end{array}$ \\
\hline Infliximab & control & 118 per 1000 & 133 per 1000 (102 to 174$)$ & OR 1.15 (0.85 to 1.57 ) & $\begin{array}{l}3403 \\
\text { (14 studies) }\end{array}$ & $\begin{array}{l}\oplus \oplus \oplus \ominus \\
\text { moderate } 1\end{array}$ & $\begin{array}{l}\text { Not statistically signif- } \\
\text { icant }\end{array}$ \\
\hline Rituximab & control & 118 per 1000 & 186 per 1000 ( 85 to 375$)$ & OR 1.71 (0.69 to 4.49 ) & $\begin{array}{l}377 \\
\text { (2 studies) }\end{array}$ & $\begin{array}{l}\oplus \oplus \oplus \odot \\
\text { moderate } 1\end{array}$ & $\begin{array}{l}\text { Not statistically signif- } \\
\text { icant }\end{array}$ \\
\hline
\end{tabular}




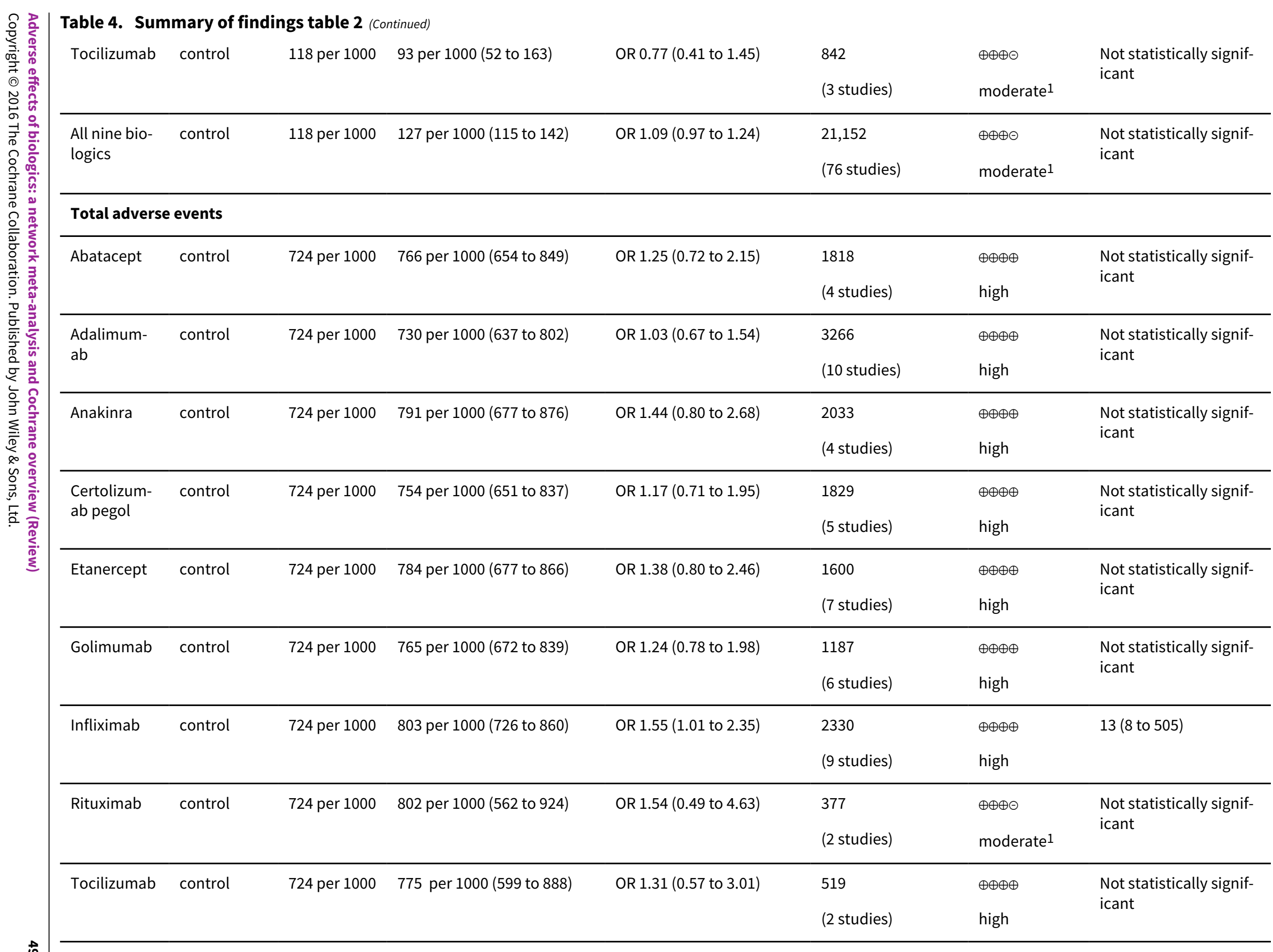




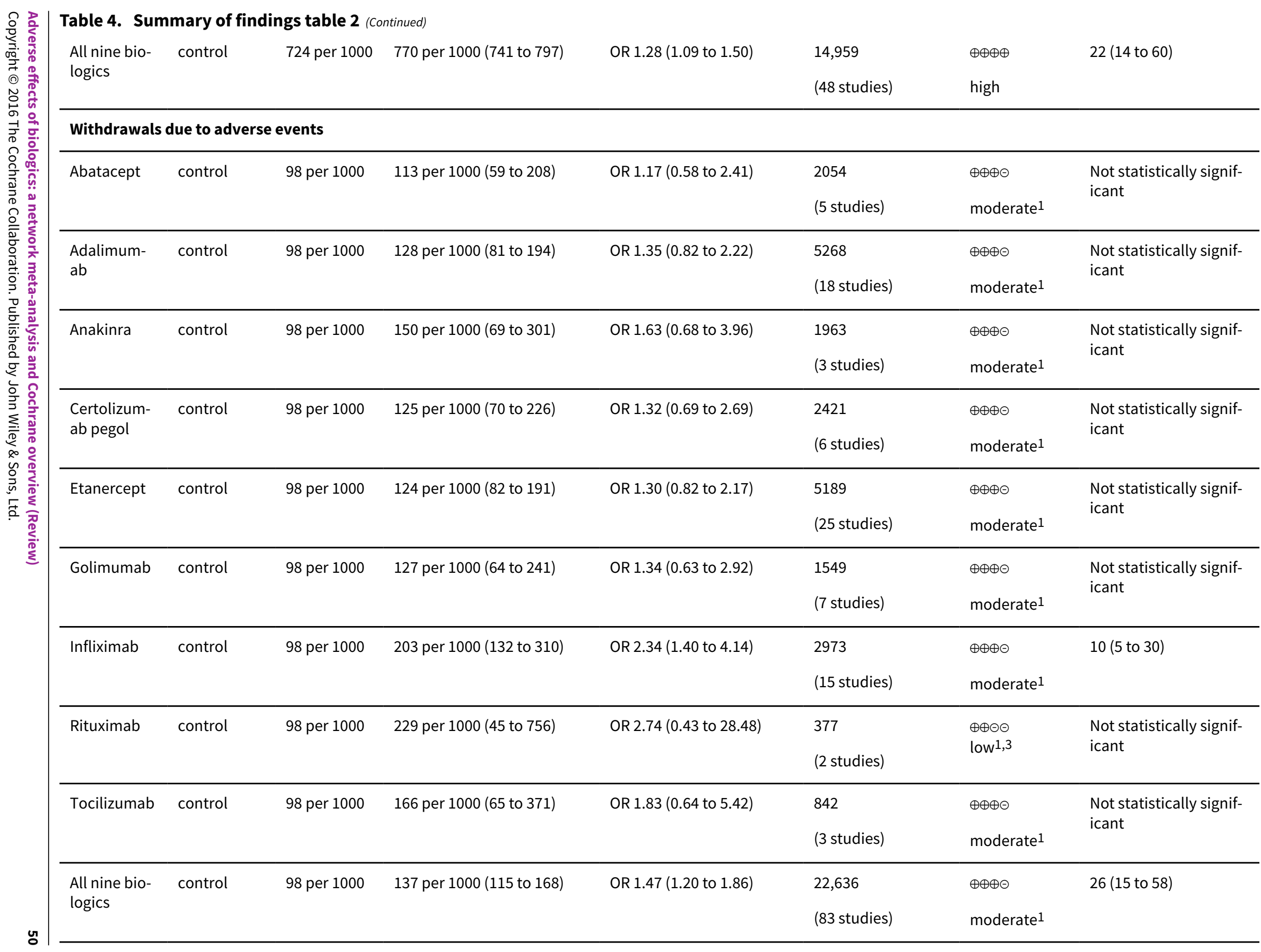




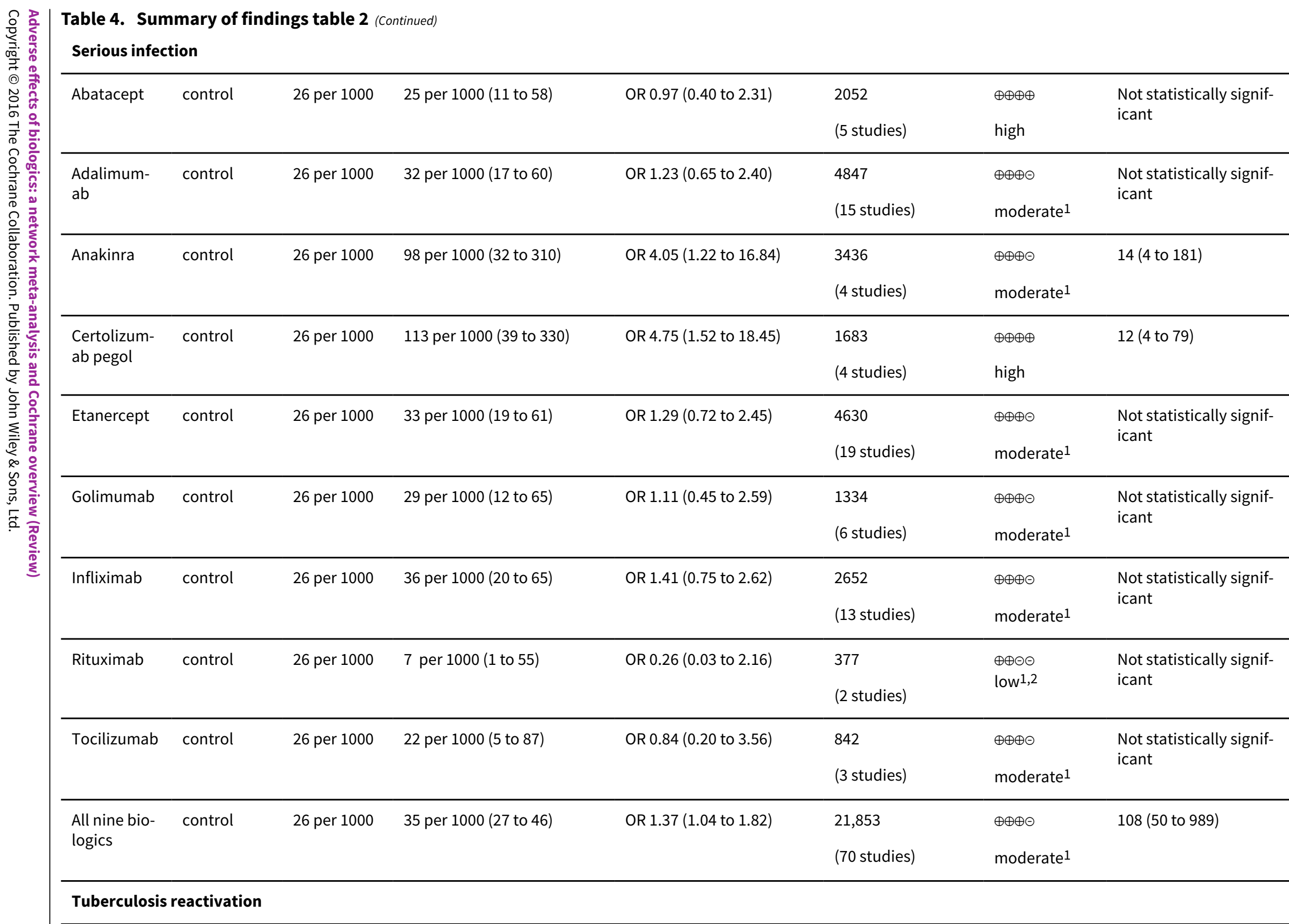


Table 4. Summary of findings table 2 (Continued)

\begin{tabular}{|c|c|c|c|c|c|c|c|}
\hline $\begin{array}{l}\text { All nine bio- } \\
\text { logics }\end{array}$ & control & 4 per 10,000 & 20 per 10,000 & OR 4.68 (1.18 to 18.60$)$ & $\begin{array}{l}30,671 \\
\text { (71 studies) }\end{array}$ & $\begin{array}{l}\oplus \oplus \ominus \ominus \\
\text { low }^{4}\end{array}$ & 681 (143 to 14706$)$ \\
\hline \multicolumn{8}{|l|}{ Lymphoma } \\
\hline $\begin{array}{l}\text { All nine bio- } \\
\text { logics }\end{array}$ & control & 9 per 10000 & 1 per 1000 & OR 0.53 (0.17 to 1.66 ) & $\begin{array}{l}21,260 \\
\text { (52 studies) }\end{array}$ & $\begin{array}{l}\oplus \oplus \oplus \ominus \\
\text { low } 4\end{array}$ & $\begin{array}{l}\text { Not statistically signif- } \\
\text { icant }\end{array}$ \\
\hline \multicolumn{8}{|c|}{ Congestive heart failure } \\
\hline $\begin{array}{l}\text { All nine bio- } \\
\text { logics }\end{array}$ & control & 8 per 1000 & $\begin{array}{l}6 \text { per } 1000 \\
(1 \text { to } 21)\end{array}$ & OR 0.69 (0.18 to 2.69 ) & $\begin{array}{l}8847 \\
\text { (24 studies) }\end{array}$ & $\begin{array}{l}\oplus \oplus \ominus \ominus \\
l o w^{4}\end{array}$ & $\begin{array}{l}\text { Not statistically signif- } \\
\text { icant }\end{array}$ \\
\hline
\end{tabular}

* = standard drug dose was used for serious adverse events, total adverse events, withdrawals due to adverse events and serious infectiosn only. All doses were combined for tuberculosis reactivation, lymphoma and congestive heart failure because of very limited data.

$95 \% \mathrm{Cl}=95 \%$ confidence interval or $95 \%$ credible interval; $\mathrm{NNTH}=$ Number needed to treat for harm; OR = odds ratio

Control event rates based on the number of events in the included studies.

1 The $95 \%$ credible interval around the pooled effect includes both no effect and appreciable benefit or harm.

2 Out of 19 studies, two studies (Buske 2009; Eve 2009) had inadequate allocation concealment; four studies (Eve 2009; Forstpointner 2004; Hainsworth 2005; Herold 2007) reported no blinding of personnel, participants and outcome assessors; two studies (Buske 2009; Salles 2007) reported no blinding of personnel and participants only.

3 Out of 15 studies, two (Buske 2009; Hiddemann 2005) had inadequate allocation concealment; four studies (Coiffier 1998; Forspointner 2004; Hainsworth 2005; Hiddemann 2005) reported no blinding of personnel, participants and outcome assessors; two studies (Forstpointner 2002; Salles 2007) reported no blinding of personnel and participants only.

4 Very few events.

Table 5. Incidence of safety outcomes from RCTs

\begin{tabular}{|c|c|c|c|c|c|c|c|c|c|c|}
\hline Outcome & $\begin{array}{l}\text { Total \# } \\
\text { studies } \\
\text { with } \\
\text { data }\end{array}$ & $\begin{array}{l}\# \\
\text { Events*: } \\
\text { biologic } \\
\text { group }\end{array}$ & $\begin{array}{l}\text { \# People: } \\
\text { biologic } \\
\text { group }\end{array}$ & $\begin{array}{l}\text { Incidence } \\
\text { in biologic } \\
\text { group }\end{array}$ & $\begin{array}{l}\text { \# } \\
\text { Events*: } \\
\text { control } \\
\text { group }\end{array}$ & $\begin{array}{l}\text { \# people: } \\
\text { control } \\
\text { group }\end{array}$ & $\begin{array}{l}\text { Incidence in } \\
\text { control group }\end{array}$ & $\begin{array}{l}\text { Total \# } \\
\text { events }\end{array}$ & $\begin{array}{l}\text { Total \# peo- } \\
\text { ple studied }\end{array}$ & $\begin{array}{l}\text { Total duration } \\
\text { of studies (mths (yrs)) }\end{array}$ \\
\hline SAE & 125 & 2926 & 26032 & $11.24 \%$ & 1747 & 13,614 & $12.83 \%$ & 4673 & 39,646 & $2613(217.8)$ \\
\hline $\begin{array}{l}\text { S Infec- } \\
\text { tions }\end{array}$ & 117 & 731 & 25,486 & $2.87 \%$ & 325 & 13,741 & $2.37 \%$ & 1056 & 39,227 & $2923(243.6)$ \\
\hline Total AE & 115 & 20,686 & 24,208 & $85.45 \%$ & 11,115 & 13,241 & $83.94 \%$ & 31,801 & 37,449 & $2462(205.2)$ \\
\hline
\end{tabular}

N 


\begin{tabular}{|c|c|c|c|c|c|c|c|c|c|c|}
\hline $\begin{array}{l}\text { With } d / t \\
A E\end{array}$ & 128 & 1577 & 26,553 & $5.94 \%$ & 683 & 14,172 & $4.82 \%$ & 2260 & 40,725 & $2909.2(242.4)$ \\
\hline TB & 71 & 32 & 20,765 & $0.154 \%$ & 3 & 9915 & $0.030 \%$ & 35 & 30,671 & $646.1(53.8)$ \\
\hline $\begin{array}{l}\text { Lym- } \\
\text { phoma }\end{array}$ & 52 & 14 & 14,254 & $0.098 \%$ & 6 & 7006 & $0.086 \%$ & 20 & 21,260 & $518.3(43.2)$ \\
\hline $\mathrm{CHF}$ & 24 & 27 & 5768 & $0.468 \%$ & 17 & 3079 & $0.552 \%$ & 44 & 8847 & $255.6(21.3)$ \\
\hline
\end{tabular}

All drug doses included

\# Events ${ }^{\star}=$ number of events or people with events

\section{Table 6. Standard meta-analyses results}

\begin{tabular}{|c|c|c|c|c|c|c|c|}
\hline & $\begin{array}{l}\text { Serious adverse } \\
\text { events }\end{array}$ & $\begin{array}{l}\text { Total adverse } \\
\text { events }\end{array}$ & $\begin{array}{l}\text { Withdrawals due to } \\
\text { adverse events }\end{array}$ & Serious Infection & TB reactivation & Lymphoma & $\begin{array}{l}\text { Congestive } \\
\text { heart failure }\end{array}$ \\
\hline Abatacept & 0.90 (0.64 to 1.28$)$ & 1.24 (0.97 to 1.60$)$ & 0.97 (0.57 to 1.63$)$ & 1.06 (0.52 to 2.16$)$ & 0.50 (0.03 to 8.11$)$ & $\begin{array}{l}1.52(0.06 \text { to } \\
37.53)\end{array}$ & $\begin{array}{l}1.56 \text { ( } 0.06 \text { to } \\
38.44)\end{array}$ \\
\hline $\begin{array}{l}\text { Adalimum- } \\
\text { ab }\end{array}$ & 0.95 (0.74 to 1.22$)$ & 0.99 (0.63 to 1.56$)$ & 1.21 (0.84 to 1.75$)$ & 1.03 (0.53 to 2.01 ) & $\begin{array}{l}2.14(0.33 \text { to } \\
13.78)\end{array}$ & $\begin{array}{l}0.95 \text { ( } 0.10 \text { to } \\
9.19)\end{array}$ & Not estimable \\
\hline Anakinra & 1.04 (0.68 to 1.61$)$ & 1.69 (0.84 to 3.42 ) & 0.65 (0.09 to 4.50$)$ & 3.24 (0.97 to 10.82$)$ & Not estimable & $\begin{array}{l}0.08 \text { (0.00 to } \\
2.08)\end{array}$ & Not estimable \\
\hline $\begin{array}{l}\text { Certolizum- } \\
\text { ab }\end{array}$ & 1.24 (0.85 to 1.80$)$ & 1.16 (0.86 to 1.56$)$ & 1.17 (0.69 to 1.97 ) & 3.15 (1.24 to 7.98$)$ & $\begin{array}{l}4.43(0.50 \text { to } \\
39.09)\end{array}$ & $\begin{array}{l}0.33 \text { (0.01 to } \\
8.09)\end{array}$ & Not estimable \\
\hline Etanercept & 1.12 (0.87 to 1.44$)$ & 1.14 (0.88 to 1.48$)$ & 0.98 (0.73 to 1.32$)$ & 1.12 (0.73 to 1.70$)$ & $\begin{array}{l}1.48(0.06 \text { to } \\
36.93)\end{array}$ & $\begin{array}{l}2.40(0.38 \text { to } \\
15.31)\end{array}$ & $\begin{array}{l}0.84(0.05 \text { to } \\
14.26)\end{array}$ \\
\hline Golimumab & 1.04 (0.64 to 1.68$)$ & 1.30 (0.85 to 1.99$)$ & 1.26 (0.57 to 2.79$)$ & 1.24 (0.61 to 2.53$)$ & $\begin{array}{l}3.04(0.12 \text { to } \\
75.13)\end{array}$ & Not estimable & $\begin{array}{l}2.84(0.11 \text { to } \\
71.99)\end{array}$ \\
\hline Infliximab & $1.06(0.82$ to 1.37$)$ & 1.51 (0.92 to 2.47 ) & 1.99 (1.04 to 3.80$)$ & 1.34 (0.85 to 2.12 ) & $\begin{array}{l}2.82(0.65 \text { to } \\
12.18)\end{array}$ & $\begin{array}{l}3.00(0.12 \text { to } \\
74.79)\end{array}$ & Not estimable \\
\hline Rituximab & 1.59 (0.51 to 4.89$)$ & 1.69 (0.97 to 2.96$)$ & 1.93 (0.18 to 21.22$)$ & $0.39(0.07$ to 2.11$)$ & --- & --- & --- \\
\hline
\end{tabular}




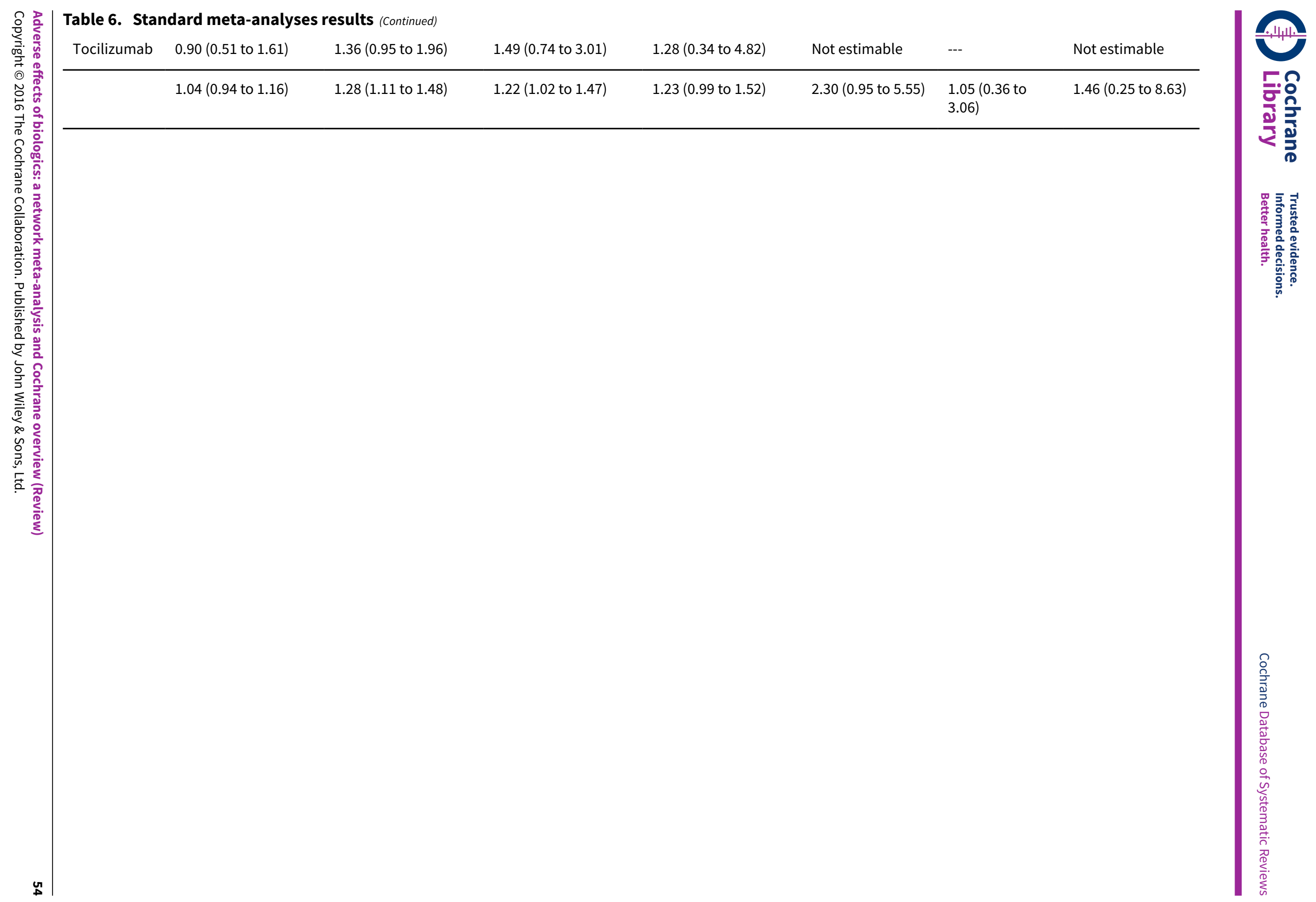


Table 7. Treatment comparison to control: serious adverse events - network meta-analysis MTC

\begin{tabular}{|c|c|}
\hline OR & Standard Dose \\
\hline \multirow[t]{2}{*}{ RE Model } & Model \\
\hline & Median $(95 \% \mathrm{Cl})$ \\
\hline Abatacept & $0.89(0.61$ to 1.26$)$ \\
\hline Adalimumab & $0.96(0.74$ to 1.27$)$ \\
\hline Anakinra & 1.04 (0.67 to 1.64$)$ \\
\hline Certolizumab & $1.57(1.06 \text { to } 2.32)^{\star}$ \\
\hline Etanercept & 1.24 (0.93 to 1.69$)$ \\
\hline Golimumab & 1.05 (0.67 to 1.69$)$ \\
\hline Infliximab & 1.15 (0.85 to 1.57$)$ \\
\hline Rituximab & 1.71 (0.69 to 4.49$)$ \\
\hline Tocilizumab & 0.77 (0.41 to 1.45$)$ \\
\hline Overall & $1.09(0.97,1.24)$ \\
\hline Data points & (133) \\
\hline Residual deviance & 153.8 \\
\hline DIC & 758.95 \\
\hline
\end{tabular}

* = statistically significant; OR = odds ratio; RE model = random-effects model; $95 \% \mathrm{Cl}=95 \%$ credible interval; DIC = Deviance information criteria

Table 8. Treatment comparison to control: total adverse events - network meta-analysis MTC

\begin{tabular}{ll}
\hline OR & Standard Dose \\
RE Model & Model \\
\hline Abatacept & Median $(95 \% \mathrm{Cl})$ \\
\hline Adalimumab & $1.25(0.72$ to 2.15$)$ \\
\hline Anakinra & $1.03(0.67$ to 1.54$)$ \\
\hline Certolizumab & $1.44(0.80$ to 2.68$)$ \\
\hline Etanercept & $1.17(0.71$ to 1.95$)$ \\
\hline Golimumab & $1.38(0.80$ to 2.46$)$ \\
\hline Infliximab & $1.24(0.78$ to 1.98$)$ \\
\hline \hline
\end{tabular}


Table 8. Treatment comparison to control: total adverse events - network meta-analysis MTC (Continued)

\begin{tabular}{ll} 
Rituximab & $1.54(0.49$ to 4.63$)$ \\
\hline Tocilizumab & $1.31(0.57$ to 3.01$)$ \\
\hline Overall & $1.28(1.09,1.50)^{\star}$ \\
\hline Data points & $(101)$ \\
Residual deviance & 113 \\
DIC & 642.73
\end{tabular}

* = statistically significant; OR = odds ratio; RE model = random-effects model; $95 \% \mathrm{Cl}=95 \%$ credible interval; DIC = Deviance information criteria

Table 9. Treatment comparison to control: withdrawals due to adverse events - network meta-analysis MTC

\begin{tabular}{|c|c|}
\hline OR & Standard Dose \\
\hline \multirow[t]{2}{*}{ RE Model } & Model \\
\hline & Median $(95 \% \mathrm{Cl})$ \\
\hline Abatacept & 1.17 (0.58 to 2.41$)$ \\
\hline Adalimumab & 1.35 (0.82 to 2.22$)$ \\
\hline Anakinra & 1.63 (0.68 to 3.96$)$ \\
\hline Certolizumab & 1.32 (0.69 to 2.69 ) \\
\hline Etanercept & $1.30(0.82$ to 2.17$)$ \\
\hline Golimumab & 1.34 (0.63 to 2.92$)$ \\
\hline Infliximab & $2.34(1.40 \text { to } 4.14)^{\star}$ \\
\hline Rituximab & 2.74 (0.43 to 28.48$)$ \\
\hline Tocilizumab & $1.83(0.64$ to 5.42$)$ \\
\hline Overall & $1.47(1.20,1.86)^{\star}$ \\
\hline Data points & $(165)$ \\
\hline Residual deviance & 161.1 \\
\hline DIC & 764.72 \\
\hline
\end{tabular}

* = statistically significant; OR = odds ratio; RE model = random-effects model; $95 \% \mathrm{Cl}=95 \%$ credible interval; DIC = Deviance information criteria

Table 10. Treatment comparison to control: serious infections - network meta-analysis MTC

\begin{tabular}{ll}
\hline OR & Standard Dose \\
RE Model & Model \\
\hline
\end{tabular}


Table 10. Treatment comparison to control: serious infections - network meta-analysis MTC (Continued) Median $(95 \% \mathrm{Cl})$

\begin{tabular}{ll}
\hline Abatacept & $0.97(0.40$ to 2.31$)$ \\
\hline Adalimumab & $1.23(0.65$ to 2.40$)$ \\
\hline Anakinra & $4.05(1.22 \text { to } 16.84)^{\star}$ \\
\hline Certolizumab & $4.75(1.52 \text { to } 18.45)^{\star}$ \\
\hline Etanercept & $1.29(0.72$ to 2.45$)$ \\
\hline Golimumab & $1.11(0.45$ to 2.59$)$ \\
\hline Infliximab & $1.41(0.75$ to 2.62$)$ \\
\hline Rituximab & $0.26(0.03$ to 2.16$)$ \\
\hline Tocilizumab & $0.84(0.20$ to 3.56$)$ \\
\hline Overall & $1.37(1.04,1.82)^{\star}$ \\
\hline Data points & $(115)$ \\
Residual deviance & 123.2 \\
DIC & 494.12 \\
\hline
\end{tabular}

* = statistically significant; OR = odds ratio; RE model = random-effects model; $95 \% \mathrm{Cl}=95 \%$ credible interval; DIC = Deviance information criteria

Table 11. Pairwise treatment comparison: serious adverse events - network meta-analysis MTC

\begin{tabular}{ll}
\hline Comparison & $\begin{array}{l}\text { Standard Dose Model } \\
\text { OR }(95 \% \mathrm{Cl})\end{array}$ \\
\hline Adalimumab vs Etanercept & $0.78(0.52$ to 1.16$)$ \\
\hline Certolizumab vs Etanercept & $1.27(0.77$ to 2.06$)$ \\
\hline Golimumab vs Etanercept & $0.85(0.49$ to 1.44$)$ \\
\hline Abatacept vs Etanercept & $0.71(0.44$ to 1.12$)$ \\
\hline Infliximab vs Etanercept & $0.93(0.60$ to 1.42$)$ \\
\hline Rituximab vs Etanercept & $1.38(0.53$ to 3.84$)$ \\
\hline Anakinra vs Etanercept & $0.84(0.49$ to 1.43$)$ \\
\hline Tocilizumab vs Etanercept & 0.62 (0.30 to 1.24$)$ \\
\hline
\end{tabular}


Table 11. Pairwise treatment comparison: serious adverse events - network meta-analysis MTC (Continued)

\begin{tabular}{lc} 
Golimumab vs Adalimumab & 1.09 (0.64 to 1.88$)$ \\
\hline Abatacept vs Adalimumab & 0.92 (0.58 to 1.42$)$ \\
\hline Infliximab vs Adalimumab & 1.19 (0.79 to 1.79$)$ \\
\hline Rituximab vs Adalimumab & 1.77 (0.68 to 4.82$)$ \\
\hline Anakinra vs Adalimumab & $1.08(0.64$ to 1.82$)$ \\
\hline Tocilizumab vs Adalimumab & $0.79(0.40$ to 1.59$)$
\end{tabular}

\begin{tabular}{lc}
\hline Golimumab vs Certolizumab & 0.67 (0.37 to 1.23$)$ \\
\hline Abatacept vs Certolizumab & 0.56 (0.33 to 0.94$)$ \\
\hline Infliximab vs Certolizumab & 0.73 (0.45 to 1.21$)$ \\
\hline Rituximab vs Certolizumab & 1.09 (0.41 to 3.07) \\
\hline Anakinra vs Certolizumab & 0.66 (0.37 to 1.21$)$ \\
\hline Tocilizumab vs Certolizumab & 0.49 (0.23 to 1.03$)$
\end{tabular}

\begin{tabular}{ll}
\hline Abatacept vs Golimumab & 0.84 (0.47 to 1.48$)$ \\
\hline Infliximab vs Golimumab & $1.09(0.62$ to 1.90$)$ \\
\hline Rituximab vs Golimumab & $1.63(0.59$ to 4.75$)$ \\
\hline Anakinra vs Golimumab & $0.99(0.52$ to 1.90$)$ \\
\hline Tocilizumab vs Golimumab & $0.73(0.34$ to 1.59$)$ \\
\hline
\end{tabular}

\begin{tabular}{lc}
\hline Infliximab vs Abatacept & 1.30 (0.84 to 2.08$)$ \\
\hline Rituximab vs Abatacept & 1.94 (0.73 to 5.43$)$ \\
\hline Anakinra vs Abatacept & 1.17 (0.67 to 2.14$)$ \\
\hline Tocilizumab vs Abatacept & $0.86(0.42$ to 1.81$)$ \\
\hline
\end{tabular}

\begin{tabular}{ll}
\hline Rituximab vs Infliximab & 1.49 (0.57 to 4.13$)$ \\
\hline Anakinra vs Infliximab & 0.91 (0.53 to 1.57$)$ \\
\hline Tocilizumab vs Infliximab & 0.67 (0.33 to 1.34$)$ \\
\hline
\end{tabular}


Table 11. Pairwise treatment comparison: serious adverse events - network meta-analysis MTC (Continued)

\begin{tabular}{ll}
\hline Anakinra vs Rituximab & $0.60(0.21$ to 1.68$)$ \\
\hline Tocilizumab vs Rituximab & $0.44(0.14$ to 1.37$)$ \\
\hline
\end{tabular}

Tocilizumab vs Anakinra

$0.74(0.34$ to 1.60$)$

*=statistically significant; OR = odds ratio; $95 \% \mathrm{Cl}=95 \%$ credible interval

Table 12. Pairwise treatment comparison: total adverse events - network meta-analysis MTC

\begin{tabular}{ll}
\hline Comparison & $\begin{array}{l}\text { Standard Dose Model } \\
\text { OR (95\% Cl) }\end{array}$ \\
\hline Adalimumab vs Etanercept & 0.74 (0.36to 1.45$)$ \\
\hline Certolizumab vs Etanercept & 0.85 (0.39to 1.77$)$ \\
\hline Golimumab vs Etanercept & $0.90(0.43$ to 1.83$)$ \\
\hline Abatacept vs Etanercept & $0.90(0.40$ to 1.94$)$ \\
\hline Infliximab vs Etanercept & $1.12(0.54$ to 2.22$)$ \\
\hline Rituximab vs Etanercept & $1.11(0.31$ to 3.80$)$ \\
\hline Anakinra vs Etanercept & $1.04(0.45$ to 2.36$)$ \\
\hline Tocilizumab vs Etanercept & 0.95 (0.34 to 2.54) \\
\hline
\end{tabular}

\begin{tabular}{lc}
\hline Certolizumab vs Adalimumab & 1.14 (0.60 to 2.24$)$ \\
\hline Golimumab vs Adalimumab & 1.20 (0.65 to 2.30$)$ \\
\hline Abatacept vs Adalimumab & $1.22(0.61$ to 2.45$)$ \\
\hline Infliximab vs Adalimumab & 1.51 (0.84 to 2.76) \\
\hline Rituximab vs Adalimumab & $1.50(0.45$ to 4.93$)$ \\
\hline Anakinra vs Adalimumab & $1.40(0.69$ to 3.00$)$ \\
\hline Tocilizumab vs Adalimumab & $1.27(0.51$ to 3.29$)$ \\
\hline
\end{tabular}

\begin{tabular}{lc}
\hline Golimumab vs Certolizumab & 1.06 (0.53 to 2.10) \\
\hline Abatacept vs Certolizumab & 1.07 (0.50 to 2.22)
\end{tabular}


Table 12. Pairwise treatment comparison: total adverse events - network meta-analysis MTC (Continued)

\begin{tabular}{lc} 
Infliximab vs Certolizumab & 1.32 (0.68 to 2.53) \\
\hline Rituximab vs Certolizumab & 1.31 (0.38 to 4.40) \\
\hline Anakinra vs Certolizumab & 1.22 (0.57 to 2.73) \\
\hline Tocilizumab vs Certolizumab & 1.11 (0.42 to 2.94)
\end{tabular}

\begin{tabular}{lc}
\hline Abatacept vs Golimumab & 1.01 (0.49 to 2.07) \\
\hline Infliximab vs Golimumab & 1.26 (0.66 to 2.33) \\
\hline Rituximab vs Golimumab & 1.25 (0.36 to 4.07) \\
\hline Anakinra vs Golimumab & 1.16 (0.55 to 2.52) \\
\hline Tocilizumab vs Golimumab & 1.06 (0.41 to 2.74 )
\end{tabular}

\begin{tabular}{lc}
\hline Infliximab vs Abatacept & 1.24 (0.65 to 2.39) \\
\hline Rituximab vs Abatacept & 1.23 (0.35 to 4.23) \\
\hline Anakinra vs Abatacept & 1.15 (0.52 to 2.66$)$ \\
\hline Tocilizumab vs Abatacept & 1.05 (0.39 to 2.8$)$
\end{tabular}

\begin{tabular}{lc}
\hline Rituximab vs Infliximab & 0.99 (0.30 to 3.24$)$ \\
\hline Anakinra vs Infliximab & 0.93 (0.45 to 1.98$)$ \\
\hline Tocilizumab vs Infliximab & 0.84 (0.33 to 2.16$)$ \\
\hline
\end{tabular}

\begin{tabular}{lc}
\hline Anakinra vs Rituximab & 0.93 (0.27 to 3.44$)$ \\
\hline Tocilizumab vs Rituximab & 0.85 (0.21 to 3.50$)$
\end{tabular}

$\begin{array}{ll}\text { Tocilizumab vs Anakinra } & 0.91(0.32 \text { to } 2.52)\end{array}$

* = statistically significant; OR = odds ratio; $95 \% \mathrm{Cl}=95 \%$ credible interval

Table 13. Pairwise treatment comparison: withdrawals due to adverse events - network meta-analysis MTC

\begin{tabular}{ll}
\hline Comparison & Standard Dose Model \\
& OR $(95 \% \mathrm{Cl})$
\end{tabular}


Table 13. Pairwise treatment comparison: withdrawals due to adverse events - network meta-analysis MTC (Continued)

\begin{tabular}{ll} 
Adalimumab vs Etanercept & 1.04 (0.51 to 2.02$)$ \\
\hline Certolizumab vs Etanercept & 1.02 (0.44 to 2.32$)$ \\
\hline Golimumab vs Etanercept & 1.03 (0.41 to 2.514$)$ \\
\hline Abatacept vs Etanercept & 0.90 (0.38 to 2.10$)$ \\
\hline Infliximab vs Etanercept & 1.81 (0.89 to 3.68$)$ \\
\hline Rituximab vs Etanercept & 2.11 (0.30 to 22.43$)$ \\
\hline Anakinra vs Etanercept & 1.26 (0.45 to 3.34) \\
\hline Tocilizumab vs Etanercept & 1.41 (0.43 to 4.53$)$
\end{tabular}

\begin{tabular}{lc}
\hline Certolizumab vs Adalimumab & 0.98 (0.43 to 2.33$)$ \\
\hline Golimumab vs Adalimumab & 1.00 (0.40 to 2.49$)$ \\
\hline Abatacept vs Adalimumab & 0.87 (0.37 to 2.09$)$ \\
\hline Infliximab vs Adalimumab & 1.74 (0.86 to 3.70$)$ \\
\hline Rituximab vs Adalimumab & $2.04(0.30$ to 22.18$)$ \\
\hline Anakinra vs Adalimumab & 1.21 (0.44 to 3.32$)$ \\
\hline Tocilizumab vs Adalimumab & $1.36(0.42$ to 4.43$)$
\end{tabular}

\begin{tabular}{ll}
\hline Golimumab vs Certolizumab & 1.01 (0.35 to 2.78$)$ \\
\hline Abatacept vs Certolizumab & 0.88 (0.33 to 2.31$)$ \\
\hline Infliximab vs Certolizumab & $1.77(0.75$ to 4.22$)$ \\
\hline Rituximab vs Certolizumab & $2.07(0.28$ to 23.37$)$ \\
\hline Anakinra vs Certolizumab & $1.23(0.40$ to 3.65$)$ \\
\hline Tocilizumab vs Certolizumab & $1.39(0.39$ to 4.85$)$ \\
\hline
\end{tabular}

\begin{tabular}{ll}
\hline Abatacept vs Golimumab & 0.87 (0.31 to 2.48$)$ \\
\hline Infliximab vs Golimumab & 1.75 (0.70 to 4.53$)$ \\
\hline Rituximab vs Golimumab & 2.05 (0.27 to 24.09) \\
\hline Anakinra vs Golimumab & 1.22 (0.38 to 3.90) \\
\hline
\end{tabular}


Table 13. Pairwise treatment comparison: withdrawals due to adverse events - network meta-analysis MTC (Continued)

Tocilizumab vs Golimumab

1.36 ( 0.37 to 5.12 )

\begin{tabular}{lc}
\hline Infliximab vs Abatacept & 2.01 (0.87 to 4.77) \\
\hline Rituximab vs Abatacept & 2.35 (0.32 to 26.5$)$ \\
\hline Anakinra vs Abatacept & 1.40 (0.45 to 4.32) \\
\hline Tocilizumab vs Abatacept & 1.57 (0.44 to 5.65$)$
\end{tabular}

\begin{tabular}{lc} 
Rituximab vs Infliximab & $1.16(0.17$ to 12.87$)$ \\
\hline Anakinra vs Infliximab & 0.70 (0.24 to 1.91$)$ \\
\hline Tocilizumab vs Infliximab & 0.78 (0.24 to 2.54$)$
\end{tabular}

\begin{tabular}{ll}
\hline Anakinra vs Rituximab & 0.59 (0.05 to 4.61$)$ \\
\hline Tocilizumab vs Rituximab & 0.67 (0.05 to 5.67) \\
\hline
\end{tabular}

Tocilizumab vs Anakinra 1.12 (0.29 to 4.49)

${ }^{*}=$ statistically significant; OR = odds ratio; $95 \% \mathrm{Cl}=95 \%$ credible interval

Table 14. Pairwise treatment comparison: serious infections - network meta-analysis MTC

\begin{tabular}{ll}
\hline Comparison & $\begin{array}{l}\text { Standard Dose Model } \\
\text { OR }(95 \% \mathrm{Cl})\end{array}$ \\
\hline Adalimumab vs Etanercept & $0.95(0.38$ to 2.29$)$ \\
\hline Certolizumab vs Etanercept & $3.68(1.01 \text { to } 16.3)^{\star}$ \\
\hline Golimumab vs Etanercept & $0.86(0.28$ to 2.39$)$ \\
\hline Abatacept vs Etanercept & $0.76(0.25$ to 2.12$)$ \\
\hline Infliximab vs Etanercept & $1.09(0.45$ to 2.56$)$ \\
\hline Rituximab vs Etanercept & $0.20(0.02$ to 1.74$)$ \\
\hline Anakinra vs Etanercept & $3.15(0.80$ to 14.5$)$ \\
\hline Tocilizumab vs Etanercept & $0.65(0.13$ to 3.07$)$ \\
\hline
\end{tabular}


Table 14. Pairwise treatment comparison: serious infections - network meta-analysis MTC (Continued)

\begin{tabular}{lc} 
Certolizumab vs Adalimumab & $3.90(1.03 \text { to } 17.17)^{\star}$ \\
\hline Golimumab vs Adalimumab & $0.90(0.29$ to 2.63$)$ \\
\hline Abatacept vs Adalimumab & 0.80 (0.26 to 2.33$)$ \\
\hline Infliximab vs Adalimumab & $1.15(0.46$ to 2.81$)$ \\
\hline Rituximab vs Adalimumab & $0.21(0.02$ to 1.89$)$ \\
\hline Anakinra vs Adalimumab & $3.33(0.83$ to 15.4$)$ \\
\hline Tocilizumab vs Adalimumab & $0.69(0.14$ to 3.32$)$
\end{tabular}

\begin{tabular}{lc}
\hline Golimumab vs Certolizumab & $0.23(0.04 \text { to } 0.97)^{\star}$ \\
\hline Abatacept vs Certolizumab & $0.20(0.04 \text { to } 0.86)^{\star}$ \\
\hline Infliximab vs Certolizumab & $0.29(0.07$ to 1.08$)$ \\
\hline Rituximab vs Certolizumab & $0.05(0.004 \text { to } 0.59)^{\star}$ \\
\hline Anakinra vs Certolizumab & $0.86(0.14$ to 5.18$)$ \\
\hline Tocilizumab vs Certolizumab & $0.17(0.02$ to 1.08$)$
\end{tabular}

\begin{tabular}{ll}
\hline Abatacept vs Golimumab & $0.88(0.26$ to 3.07$)$ \\
\hline Infliximab vs Golimumab & $1.27(0.45$ to 3.81$)$ \\
\hline Rituximab vs Golimumab & $0.24(0.02$ to 2.26$)$ \\
\hline Anakinra vs Golimumab & $3.68(0.84$ to 19.96$)$ \\
\hline Tocilizumab vs Golimumab & $0.75(0.15$ to 4.32$)$ \\
\hline
\end{tabular}

\begin{tabular}{ll}
\hline Infliximab vs Abatacept & 1.44 (0.53 to 4.07$)$ \\
\hline Rituximab vs Abatacept & $0.27(0.02$ to 2.68$)$ \\
\hline Anakinra vs Abatacept & 4.20 (0.96 to 22.06$)$ \\
\hline Tocilizumab vs Abatacept & $0.86(0.16$ to 4.76$)$ \\
\hline
\end{tabular}

\begin{tabular}{ll}
\hline Rituximab vs Infliximab & 0.19 (0.02 to 1.65$)$ \\
\hline Anakinra vs Infliximab & $2.90(0.75$ to 13.41$)$
\end{tabular}


Table 14. Pairwise treatment comparison: serious infections - network meta-analysis MTC (Continued)

* = statistically significant; $\mathrm{OR}=$ odds ratio; $95 \% \mathrm{Cl}=95 \%$ credible interval 


\begin{tabular}{|c|c|c|c|c|c|c|c|c|}
\hline \multirow[t]{2}{*}{ Factor } & \multicolumn{2}{|c|}{ Total adverse events } & \multicolumn{2}{|c|}{ Serious adverse effects } & \multicolumn{2}{|l|}{ Serious infections } & \multicolumn{2}{|c|}{$\begin{array}{l}\text { Withdrawals due to adverse ef } \\
\text { fects }\end{array}$} \\
\hline & OR $(95 \% \mathrm{Cl})$ & $\begin{array}{l}\text { Tau } \\
\text { squared }\end{array}$ & OR $(95 \% \mathrm{Cl})$ & $\begin{array}{l}\text { Tau } \\
\text { squared }\end{array}$ & OR $(95 \% \mathrm{CI})$ & $\begin{array}{l}\text { Tau } \\
\text { squared }\end{array}$ & OR $(95 \% \mathrm{CI})$ & $\begin{array}{l}\text { Tau } \\
\text { squared }\end{array}$ \\
\hline $\begin{array}{l}\text { Overall biologics (vs } \\
\text { control) }\end{array}$ & $\begin{array}{l}1.06 \\
\text { (1.03 to } 1.10) \\
P=0.0006\end{array}$ & 1.064 & $\begin{array}{l}1.17 \\
\text { (0.90 to } 1.53 \text { ) } \\
P=\mathbf{0 . 2 4 4 8}\end{array}$ & 0.846 & $\begin{array}{l}1.39 \\
\text { (1.18 to } 1.64) \\
P=\mathbf{0 . 0 0 0 3}\end{array}$ & 1.187 & $\begin{array}{l}1.43 \\
(1.23 \text { to } 1.66) \\
P<0.0001\end{array}$ & 1.126 \\
\hline By drug (vs Control) & $P=0.0216$ & 1.064 & $P=0.3126$ & 0.897 & $P=0.0043$ & 1.144 & $P=0.0006$ & 1.075 \\
\hline Abatacept & $\begin{array}{l}1.05 \\
\text { (0.93 to } 1.17)\end{array}$ & & 1.01 (0.77 to 1.31$)$ & & 1.11 (0.66 to 1.87 ) & & 1.14 (0.71 to 1.84$)$ & \\
\hline Adalimumab & 1.00 (0.93 to 1.08$)$ & & 0.92 (0.74 to 1.15$)$ & & $1.24(0.81$ to 1.88$)$ & & 1.21 (0.86 to 1.71$)$ & \\
\hline Anakinra & 1.01 (0.88 to 1.16$)$ & & 1.00 (0.67 to 1.49$)$ & & $1.83(0.85$ to 3.95$)$ & & 1.61 (0.86 to 3.01$)$ & \\
\hline Certolizumab pegol & $1.05(0.91$ to 1.21$)$ & & 1.49 (1.06 to 2.02 ) & & 2.82 (1.27 to 6.29$)$ & & 1.39 (0.85 to 2.29$)$ & \\
\hline Etanercept & $1.10(1.01$ to 1.20$)$ & & $1.13(0.90$ to 1.41$)$ & & 1.10 (0.74 to 1.65$)$ & & 1.25 (0.90 to 1.72 ) & \\
\hline Golimumab & 1.06 (0.93 to 1.20$)$ & & $1.00(0.71$ to 1.41$)$ & & 1.37 (0.77 to 2.44$)$ & & 1.35 (0.79 to 2.30$)$ & \\
\hline Infliximab & $1.16(1.07$ to 1.27$)$ & & 1.19 (0.99 to 1.43 ) & & 1.97 (1.41 to 2.75$)$ & & 2.15 (1.60 to 2.89 ) & \\
\hline Rituximab & 1.04 (0.96 to 1.13 ) & & 1.02 (0.84 to 1.23 ) & & 1.12 (0.81 to 1.54$)$ & & 1.21 (0.77 to 1.89$)$ & \\
\hline Tocilizumab & $1.10(0.97$ to 1.26$)$ & & 1.14 (0.79 to 1.63$)$ & & 1.67 (0.92 to 3.06$)$ & & 1.54 (0.88 to 2.67 ) & \\
\hline TNF-alpha inhibitor: & $P=0.0021$ & 1.031 & $P=0.4927$ & 0.858 & $P=0.0002$ & 1.121 & $P<0.0001$ & 1.061 \\
\hline Yes & 1.07 (1.03 to 1.12$)$ & & $1.25(0.92$ to 1.71$)$ & & 1.41 (1.13 to 1.75$)$ & & 1.41 (1.18 to 1.68$)$ & \\
\hline No & 1.06 (1.00 to 1.12 ) & & 0.99 (0.62 to 1.59$)$ & & 1.37 (1.05 to 1.78$)$ & & 1.50 (1.13 to 1.99$)$ & \\
\hline
\end{tabular}




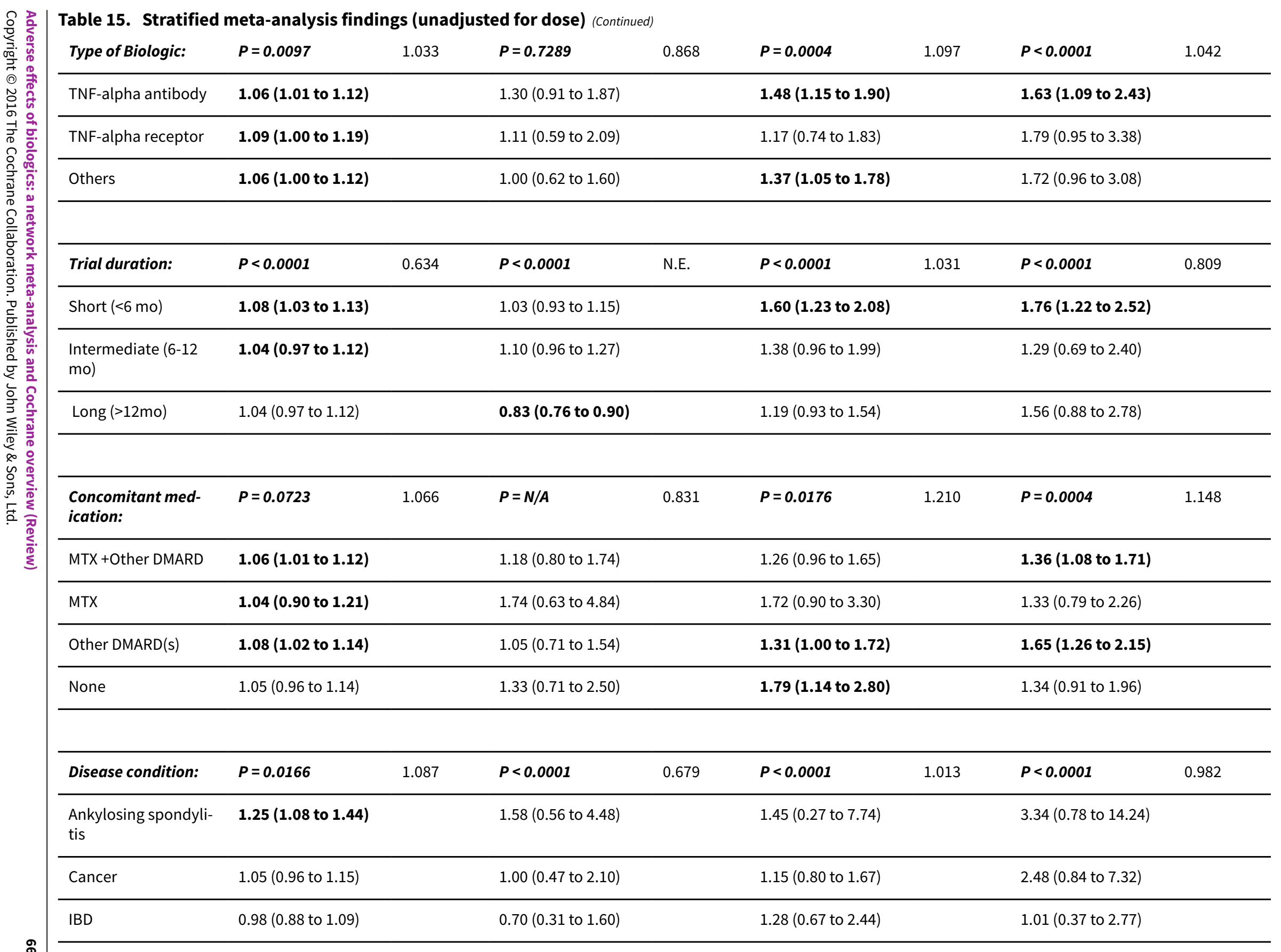

15. Stratified meta-analysis findings (unadjusted for dose) (Continued) 
Table 15. Stratified meta-analysis findings (unadjusted for dose) (Continued)

Psoriasis

$1.17(1.06$ to 1.30$)$

$1.25(0.5$ to 3.08$)$

$0.70(0.28$ to 1.77$)$

$1.34(0.52$ to 3.45$)$

\begin{tabular}{lllll}
\hline Psoriatic arthritis & $1.03(0.87$ to 1.22$)$ & $0.59(0.18$ to 2.01$)$ & $0.29(0.07$ to 1.25$)$ & $1.26(0.31$ to 5.07$)$ \\
\hline Rheumatoid arthritis & $\mathbf{1 . 0 5}(\mathbf{1 . 0 0}$ to $\mathbf{1 . 0 9})$ & $1.31(0.92$ to 1.88$)$ & $\mathbf{1 . 5 5}(\mathbf{1 . 2 3}$ to $\mathbf{1 . 9 5 )}$ & $1.44(0.95$ to 2.20$)$ \\
\hline Other $^{*}$ & $1.07(0.96$ to 1.19$)$ & $1.37(0.77$ to 2.44$)$ & $\mathbf{1 . 6 1}(\mathbf{1 . 0 9}$ to $\mathbf{2 . 3 6})$ & $\mathbf{3 . 6 5}(\mathbf{1 . 6 7}$ to 8.18$)$
\end{tabular}

$\mathrm{N}=$ number of; $\mathrm{OR}=$ odds ratio $\mathrm{Cl}=$ confidence interval; $\mathrm{P}=\mathrm{P}$ value; $\mathrm{TNF}$-alpha inhibitor $=$ tumor necrosis factor - alpha inhibitor; $\mathrm{N} / \mathrm{A}=$ not applicable; $\mathrm{N} . \mathrm{E} .=$ not estimable; $\mathrm{MTX}=$ methotrexate; DMARD = disease modifying anti-rheumatic drug; IBD = inflammatory bowel disease; Other ${ }^{\star}=$ other disease conditions - includes: heart failure, multiple sclerosis, COPD, alcoholic hepatitis, diabetes, lupus, active spondylarthropathy, osteoarthritis, asthma, cardiac or renal transplantation, Sjogren's syndrome, polymyalgia rheumatica, autoimmune inner ear disease, giant cell arteritis, pulmonary sarcoidosis, Hepatitis C, cancer anorexia/weight loss syndrome, Wegener's granulomatosis, Crohn's disese and ulcerative colitis.

The results in this table are not adjusted for dose.

Note: we defined the comparison of TNF antibody versus receptor versus other as follows: TNF antibody (infliximab, golimumab, certolizumab pegol, adalimumab) versus TNF receptor (etanercept) versus other (tocilizumab, rituximab, abatacept). The 'other' types of concomitant medication included DMARDs, steroids and/or NSAIDs.

Note: we did not have enough data for the models to run on the stratified analysis for congestive heart failure, lymphoma, and TB reactivation outcomes.

Table 16. Estimates of safety outcomes from extension studies

\begin{tabular}{|c|c|c|c|c|c|c|c|c|c|}
\hline & $\begin{array}{l}\text { Abat- } \\
\text { a- } \\
\text { cept }\end{array}$ & $\begin{array}{l}\text { Adali- } \\
\text { mum- } \\
\text { ab }\end{array}$ & $\begin{array}{l}\text { Anakin- } \\
\text { ra }\end{array}$ & $\begin{array}{l}\text { Cer- } \\
\text { tolizum- } \\
\text { ab } \\
\text { pegol }\end{array}$ & $\begin{array}{l}\text { Etaner- } \\
\text { cept }\end{array}$ & $\begin{array}{l}\text { Goli- } \\
\text { mum- } \\
\text { ab }\end{array}$ & $\begin{array}{l}\text { Inflix- } \\
\text { imab }\end{array}$ & $\begin{array}{l}\text { Rit- } \\
\text { ux- } \\
\text { imab }\end{array}$ & $\begin{array}{l}\text { Tocilizum- } \\
\text { ab }\end{array}$ \\
\hline Patients & 604 & 2564 & 427 & 781 & 5342 & 137 & 917 & 1039 & 143 \\
\hline Estimated Patient Months & 22926 & 34526 & 8113 & 9372 & 173016 & 1644 & 17855 & 49872 & 8580 \\
\hline
\end{tabular}

\begin{tabular}{|c|c|c|c|c|c|c|c|c|c|c|}
\hline Outcome measure & Cour & sRisk Counts & Risk C & tsRisKounts & Risk Counts & Risk Counts & Risk Counts & Risk Counts & Risk Cou & sRisk \\
\hline Serious AE, events & 132 & $46.0 \% 227$ & $9.0 \%$ & 93 & $11.9 \% 55$ & $10.4 \% 2$ & $16.1 \% 16$ & $12.9 \% 16$ & $30.4 \% 7$ & $53.8 \%$ \\
\hline Serious $A E$, patients & 287 & 2522 & . & 781 & 3406 & 137 & 898 & 1039 & 143 & . \\
\hline Serious Infections, events & . & 62 & $2.5 \%$ & 7 & $0.9 \% 178$ & $3.9 \% 3$ & $2.2 \% 42$ & $5.1 \% 84$ & $8.1 \% 25$ & $17.5 \%$ \\
\hline Serious Infections, patients & . & 2476 & . & 781 & 4577 & 137 & 831 & 1039 & 143 & . \\
\hline
\end{tabular}




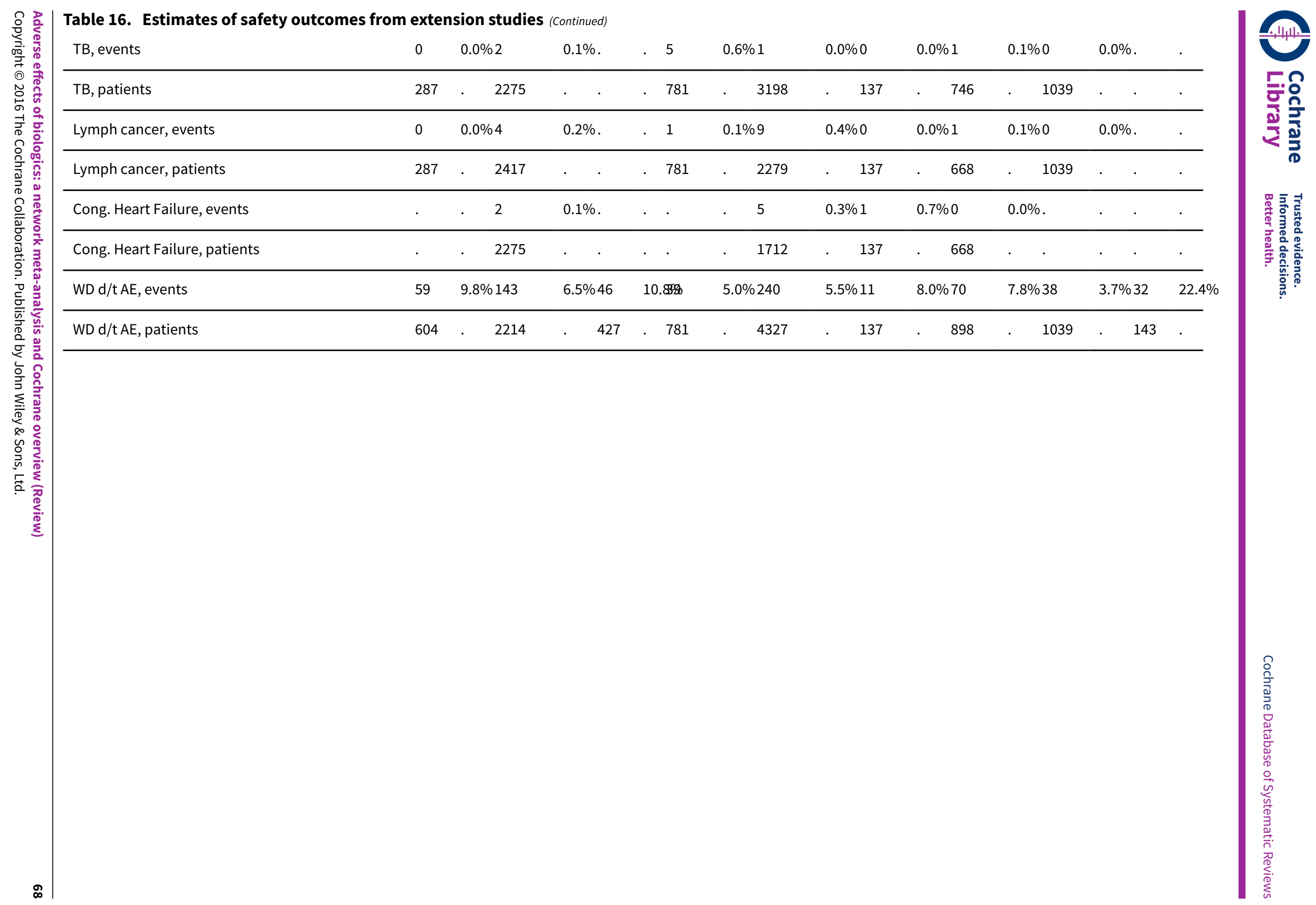




\section{AP PEN DICES}

\section{Appendix 1. Systematic review search strategy}

The Cochrane Library, Issue 1, 2010

Cochrane Database of Systematic Reviews (limited to Reviews only):

DARE:

HTA:

\section{CENTRAL:}

\#1 MeSH descriptor Antibodies, Monoclonal explode all trees

\#2 MeSH descriptor Monokines explode all trees

\#3 MeSH descriptor Receptors, Interleukin-1 explode all trees

\#4 MeSH descriptor Receptors, Interleukin-6 explode all trees

\#5 MeSH descriptor Immunoglobulin G explode all trees

\#6 MeSH descriptor Immunoconjugates explode all trees

\#7 MeSH descriptor Polyethylene Glycols explode all trees

\#8 MeSH descriptor Immunoglobulin Fab Fragments explode all trees

\#9 MeSH descriptor T-Lymphocytes explode all trees

\#10 adalimumab:ti,ab

\#11 humira:ti,ab

\#12 trudexa:ti,ab

\#13 abatacept:ti,ab

\#14 orencia:ti,ab

\#15 anakinra:ti,ab

\#16 kineret:ti,ab

\#17 Certolizumab:ti,ab

\#18 cimzia:ti,ab

\#19 Etanercept:ti,ab

\#20 enbrel:ti,ab

\#21 Golimumab:ti,ab

\#22 simponi:ti,ab

\#23 rituximab:ti,ab

\#24 rituxan:ti,ab

\#25 mabthera:ti,ab

\#26 Tocilizumab:ti,ab

\#27 actemra:ti,ab

\#28 RoActemra:ti,ab 
\#29 (\#1 OR \#2 OR \#3 OR \#4 OR \#5 OR \#6 OR \#7 OR \#8 OR \#9 OR \#10 OR \#11 OR \#12 OR \#13 OR \#14 OR \#15 OR \#16 OR \#17 OR \#18 OR \#19 OR \#20 OR \#21 OR \#22 OR \#23 OR \#24 OR \#25 OR \#26 OR \#27 OR \#28)

\section{Appendix 2. RCT, CCT, open label extension update search strategy}

\section{MEDLINE 2005 to January Week 42010}

1. exp antibodies, monoclonal/

2. exp monokines/

3. exp receptors, interleukin-1/

4. exp receptors, interleukin-6/

5. exp immunoglobuling/

6. exp immunoconjugates/

7. exp polyethylene glycols/

8. exp immunoglobulin fab fragments/

9. exp t-lymphocytes/

10. adalimumab.tw.

11. humira.tw.

12. trudexa.tw.

13. abatacept.tw

14. orencia.tw.

15. anakinra.tw.

16. kineret.tw.

17. Certolizumab.tw.

18. cimzia.tw.

19. Etanercept.tw.

20. enbrel.tw.

21. Golimumab.tw.

22. simponi.tw

23. rituximab.tw.

24. rituxan.tw.

25. mabthera.tw.

26. Tocilizumab.tw.

27. actemra.tw.

28. RoActemra.tw.

29. or/1-28

30. limit 29 to (yr="2005 -Current" and randomized controlled trial)

II. EMBASE 2006 to 2010 Week 05

1. adalimumab/

Adverse effects of biologics: a network meta-analysis and Cochrane overview (Review) 
2. adalimumab.tw.

3. humira.tw.

4. trudexa.tw.

5. abatacept/

6. abatacept.tw.

7. orencia.tw.

8. recombinant interleukin 1 receptor blocking agent/

9. anakinra.tw.

10. kineret.tw.

11. certolizumab pegol/

12. Certolizumab.tw.

13. cimzia.tw.

14. etanercept/

15. Etanercept.tw.

16. enbrel.tw.

17. golimumab/

18. Golimumab.tw.

19. simponi.tw.

20. rituximab/

21. rituximab.tw.

22. ritux?n.tw.

23. mabthera.tw.

24. atlizumab/

25. Tocilizumab.tw.

26. actemra.tw.

27. RoActemra.tw.

28. or/1-27

29. (random\$ or placebo\$).ti,ab.

30. ((single\$ or double\$ or triple\$ or treble\$) and (blind\$ or mask\$)).ti,ab.

31. controlled clinical trial\$.ti,ab.

\section{RETRACTED ARTICLE/}

33. or $/ 29-32$

34. (animal\$ not human\$).sh,hw.

35.33 not 34

36. 28 and 35

Adverse effects of biologics: a network meta-analysis and Cochrane overview (Review) 
37. limit 36 to $y r=" 2006$-Current"

\section{Appendix 3. Adverse event search strategy}

\section{MEDLINE 1950 to January Week 42010}

1. adalimumab.tw.

2. humira.tw.

3. trudexa.tw.

4. abatacept.tw.

5. orencia.tw.

6. anakinra.tw.

7. kineret.tw.

8. Certolizumab.tw.

9. cimzia.tw.

10. Etanercept.tw.

11. enbrel.tw.

12. Golimumab.tw.

13. simponi.tw.

14. rituximab.tw.

15. rituxan.tw.

16. mabthera.tw.

17. Tocilizumab.tw.

18. actemra.tw.

19. RoActemra.tw.

20. or/1-19

21. (safe or safety).tw.

22. side effect\$.tw.

23. ((adverse or undesirable or harms\$ or serious or toxic) adj3 (effect\$ or reaction\$ or event\$ or outcome\$)).tw.

24. exp product surveillance, postmarketing/

25. exp adverse drug reaction reporting systems/

26. clinical trials, phase iv/

27. Clinical Trials, Phase III/

28. exp poisoning/

29. exp substance-related disorders/

30. exp drug toxicity/

31. exp abnormalities, drug induced/

32. exp drug monitoring/ 
33. exp drug hypersensitivity/

34. (toxicity or complication\$ or noxious or tolerability).tw.

35. exp Postoperative Complications/

36. exp Intraoperative Complications/

37. extension.tw.

38. continuation.tw.

39. (follow-on or follow-up).tw.

40. long-term data.tw.

41. or $/ 21-40$

42. 20 and 41

\section{EMBASE 1980 to 2010 Week 05}

1. adalimumab.tw.

2. humira.tw.

3. trudexa.tw.

4. abatacept.tw.

5. orencia.tw.

6. anakinra.tw.

7. kineret.tw.

8. Certolizumab.tw.

9. cimzia.tw.

10. Etanercept.tw.

11. enbrel.tw.

12. Golimumab.tw.

13. simponi.tw.

14. rituximab.tw

15. ritux?n.tw.

16. mabthera.tw.

17. Tocilizumab.tw.

18. actemra.tw.

19. RoActemra.tw.

20. or/1-19

21. (ae or si or to or co).fs.

22. (adverse adj (effect\$ or reaction\$ or event\$ or incident\$)).tw.

23. toxic\$.tw.

24. ((injurious or undesirable) adj (effect\$ or reaction\$ or event\$ or incident\$)).tw. 
25. safety.tw.

26. ((drug or chemical\$) adj induced).tw.

27. extension.tw.

28. continuation.tw.

29. follow-on.tw.

30. (follow-up adj5 trial).tw.

31. long-term data.tw.

32. or/21-31

33. 20 and 32

Appendix 4. Treatment comparison to control: serious adverse events - network meta-analysis MTC

\begin{tabular}{|c|c|c|c|}
\hline OR & Standard Dose & Unadjusted & Dose Adjusted \\
\hline \multirow[t]{2}{*}{ RE Model } & Model & Model & Model \\
\hline & Median $(95 \% \mathrm{Cl})$ & Median $(95 \% \mathrm{Cl})$ & Median (95\% Cl) \\
\hline Abatacept & 0.89 (0.61 to 1.26$)$ & 1.02 (0.71 to 1.47$)$ & 0.88 (0.45 to 1.70$)$ \\
\hline Adalimumab & $0.96(0.74$ to 1.27$)$ & $0.90(0.67$, to 1.20$)$ & 1.01 (0.64 to 1.59$)$ \\
\hline Anakinra & 1.04 (0.67 to 1.64$)$ & 1.05 (0.61 to 1.85$)$ & 1.06 (0.58 to 1.94$)$ \\
\hline Certolizumab & $1.57(1.06 \text { to } 2.32)^{\star}$ & $1.66(1.08 \text { to } 2.59)^{*}$ & 1.57 (0.96 to 2.57$)$ \\
\hline Etanercept & 1.24 (0.93 to 1.69$)$ & 1.25 (0.92 to 1.72$)$ & 1.29 (0.90 to 1.87$)$ \\
\hline Golimumab & 1.05 (0.67 to 1.69 ) & 1.06 (0.68 to 1.63 ) & $1.03(0.60$ to 1.74$)$ \\
\hline Infliximab & 1.15 (0.85 to 1.57$)$ & 1.24 (0.97 to 1.62$)$ & 1.13 (0.79 to 1.62$)$ \\
\hline Rituximab & 1.71 (0.69 to 4.49$)$ & $1.38(1.03 \text { to } 1.86)^{*}$ & 1.44 (0.57 to 3.59$)$ \\
\hline Tocilizumab & $0.77(0.41$ to 1.45$)$ & 1.11 (0.70 to 1.77$)$ & 1.16 (0.25 to 4.77$)$ \\
\hline Overall & 1.09 (0.97 to 1.24$)$ & & \\
\hline Data points & (133) & $(211)$ & $(261)$ \\
\hline Residual deviance & 153.8 & 285.6 & 282.7 \\
\hline DIC & 758.95 & 1368.36 & 1377.79 \\
\hline
\end{tabular}

\section{Footnotes}

* = statistically significant; OR = odds ratio; RE model = random-effects model; $95 \% \mathrm{Cl}=95 \%$ credible interval; DIC = Deviance information criteria

\section{Appendix 5. Treatment comparison to control: total adverse events - network meta-analysis MTC}




\begin{tabular}{|c|c|c|c|}
\hline OR & Standard Dose & Unadjusted & Dose Adjusted \\
\hline \multirow[t]{2}{*}{ RE Model } & Model & Model & Model \\
\hline & Median $(95 \% \mathrm{Cl})$ & Median $(95 \% \mathrm{Cl})$ & Median $(95 \% \mathrm{Cl})$ \\
\hline Abatacept & 1.25 (0.72 to 2.15$)$ & $1.10(0.73$ to 1.66$)$ & 1.24 (0.74 to 2.07$)$ \\
\hline Adalimumab & 1.03 (0.67 to 1.54$)$ & $1.04(0.75$ to 1.45$)$ & $0.86(0.51$ to 1.44$)$ \\
\hline Anakinra & 1.44 (0.80 to 2.68$)$ & 1.19 (0.74 to 1.92$)$ & 1.38 (0.79 to 2.41$)$ \\
\hline Certolizumab & 1.17 (0.71 to 1.95$)$ & $1.18(0.77$ to 1.80$)$ & $1.17(0.74$ to 1.88$)$ \\
\hline Etanercept & $1.38(0.80$ to 2.46$)$ & $1.13(0.71$ to 1.81$)$ & 1.20 (0.71 to 2.06$)$ \\
\hline Golimumab & 1.24 (0.78 to 1.98$)$ & 1.18 (0.81 to 1.69$)$ & 1.15 (0.74 to 1.79$)$ \\
\hline Infliximab & $1.55(1.01 \text { to } 2.35)^{\star}$ & $1.54(1.17 \text { to } 2.03)^{\star}$ & 1.45 (0.98 to 2.11$)$ \\
\hline Rituximab & 1.54 (0.49 to 4.63 ) & 1.49 (0.94 to 2.40$)$ & 1.28 (0.49 to 3.37$)$ \\
\hline Tocilizumab & $1.31(0.57$ to 3.01$)$ & 1.34 (0.85 to 2.10$)$ & 1.11 (0.53 to 2.28$)$ \\
\hline Overall & $1.28(1.09 \text { to } 1.50)^{\star}$ & & \\
\hline Data points & $(101)$ & $(160)$ & (163) \\
\hline Residual deviance & 113 & 178.4 & 175.9 \\
\hline DIC & 642.73 & 1012.58 & 1016.75 \\
\hline
\end{tabular}

\section{Footnotes}

* = statistically significant; OR = odds ratio; RE model = random-effects model; $95 \% \mathrm{Cl}=95 \%$ credible interval; DIC = Deviance information criteria

Appendix 6. Treatment comparison to control: withdrawals due to adverse events - network meta-analysis MTC

\begin{tabular}{llll}
\hline OR & Standard Dose & Unadjusted & Dose Adjusted \\
RE Model & $\begin{array}{l}\text { Model } \\
\text { Median }(95 \% \mathrm{Cl})\end{array}$ & $\begin{array}{l}\text { Model } \\
\text { Median }(95 \% \mathrm{Cl})\end{array}$ & Median $(95 \% \mathrm{Cl})$ \\
\hline Abatacept & $1.17(0.58$ to 2.41$)$ & $1.21(0.69$ to 2.12$)$ & $1.04(0.51$ to 2.12$)$ \\
\hline Adalimumab & $1.35(0.82$ to 2.22$)$ & $1.16(0.77$ to 1.74$)$ & $1.38(0.87$ to 2.20$)$ \\
\hline Anakinra & $1.63(0.68$ to 3.96$)$ & $1.63(0.78$ to 3.48$)$ & $1.62(0.73$ to 3.71$)$ \\
\hline Certolizumab & $1.32(0.69$ to 2.69$)$ & $1.32(0.75$ to 2.40$)$ & $1.31(0.70$ to 2.52$)$ \\
\hline Etanercept & $1.30(0.82$ to 2.17$)$ & $1.35(0.92$ to 2.02$)$ & $1.36(0.88$ to 2.16$)$ \\
\hline
\end{tabular}




\begin{tabular}{llll}
$\begin{array}{l}\text { (Continued) } \\
\text { Golimumab }\end{array}$ & $1.34(0.63$ to 2.92$)$ & $1.43(0.78$ to 2.66$)$ & $1.28(0.62$ to 2.67$)$ \\
\hline Infliximab & $2.34(1.40 \text { to } 4.14)^{\star}$ & $2.32(1.63 \text { to } 3.37)^{\star}$ & $2.29(1.45 \text { to } 3.73)^{\star}$ \\
\hline Rituximab & $2.74(0.43$ to 28.48$)$ & $2.50(1.36 \text { to } 4.88)^{\star}$ & $1.78(0.38$ to 8.43$)$ \\
\hline Tocilizumab & $1.83(0.64$ to 5.42$)$ & $1.47(0.79$ to 2.79$)$ & $1.57(0.63$ to 3.90$)$ \\
\hline Overall & $1.47(1.20 \text { to } 1.86)^{\star}$ & & $(266)$ \\
\hline Data points & $(165)$ & $(264)$ & 270.6 \\
Residual deviance & 161.1 & 268.6 & 1259.71 \\
DIC & 764.72 & 1247.06 & \\
\hline
\end{tabular}

\section{Footnotes}

${ }^{*}$ = statistically significant; OR = odds ratio; RE model = random-effects model; $95 \% \mathrm{Cl}=95 \%$ credible interval; DIC $=$ Deviance information criteria

\section{Appendix 7. Treatment comparison to control: serious infections - network meta-analysis MTC}

\begin{tabular}{|c|c|c|c|}
\hline OR & Standard Dose & Unadjusted & Dose Adjusted \\
\hline \multirow[t]{2}{*}{ RE Model } & Model & Model & Model \\
\hline & Median $(95 \% \mathrm{Cl})$ & Median $(95 \% \mathrm{Cl})$ & Median $(95 \% \mathrm{CI})$ \\
\hline Abatacept & 0.97 (0.40 to 2.31$)$ & 1.19 (0.62 to 2.27$)$ & 1.08 (0.48 to 2.48$)$ \\
\hline Adalimumab & 1.23 (0.65 to 2.40$)$ & 1.26 (0.74 to 2.20$)$ & 1.30 (0.73 to 2.42$)$ \\
\hline Anakinra & $4.05(1.22 \text { to } 16.84)^{\star}$ & $3.96(1.27 \text { to } 15.75)^{\star}$ & $4.03(1.29 \text { to } 16.22)^{\star}$ \\
\hline Certolizumab & $4.75(1.52 \text { to } 18.45)^{\star}$ & $4.65(1.61 \text { to } 16.22)^{\star}$ & $4.67(1.58 \text { to } 16.15)^{\star}$ \\
\hline Etanercept & 1.29 (0.72 to 2.45$)$ & 1.19 (0.72 to 2.01$)$ & 1.28 (0.73 to 2.30$)$ \\
\hline Golimumab & 1.11 (0.45 to 2.59 ) & 1.30 (0.65 to 2.65$)$ & 1.14 (0.49 to 2.55 ) \\
\hline Infliximab & 1.41 (0.75 to 2.62 ) & $1.58(1.08 \text { to } 2.36)^{\star}$ & 1.17 (0.65 to 2.09 ) \\
\hline Rituximab & 0.26 (0.03 to 2.16$)$ & $1.17(0.76$ to 1.85$)$ & $0.46(0.16$ to 1.15$)$ \\
\hline Tocilizumab & 0.84 (0.20 to 3.56$)$ & 1.52 (0.72 to 3.32$)$ & $0.78(0.22$ to 2.60$)$ \\
\hline Overall & $1.37(1.04 \text { to } 1.82)^{\star}$ & & \\
\hline Data points & $(115)$ & $(163)$ & (208) \\
\hline Residual deviance & 123.2 & 221.8 & 221.5 \\
\hline DIC & 494.12 & 895.53 & 902.03 \\
\hline
\end{tabular}




\section{Footnotes}

${ }^{\star}$ = statistically significant; $\mathrm{OR}=$ odds ratio; $\mathrm{RE}$ model = random-effects model; $95 \% \mathrm{Cl}=95 \%$ credible interval; DIC = Deviance information criteria

\section{Appendix 8. Sensitivity/meta-regression analysis for serious infection (certolizumab versus placebo)}

\begin{tabular}{ll}
\hline Model & OR (95\% credible interval) \\
\hline Random effects (RE) & $4.75(1.52,18.45)$ \\
\hline Fixed effects (FE) & $4.16(1.69,12.57)$ \\
\hline RE remove cancer trials & $4.71(1.51,18.10)$ \\
\hline RE meta-regression control rate & $4.67(1.46,18.06)$ \\
\hline RE meta-regression trial length & $5.26(1.52,24.35)$ \\
\hline
\end{tabular}

Appendix 9. Pairwise treatment comparison: serious adverse events - network meta-analysis MTC

\begin{tabular}{|c|c|c|c|}
\hline Comparison & Standard Dose Model & Unadjusted Dose Model & Dose Adjusted Model \\
\hline & OR $(95 \% \mathrm{Cl})$ & OR $(95 \% \mathrm{Cl})$ & OR $(95 \% \mathrm{Cl})$ \\
\hline Adalimumab vs Etanercept & $0.78(0.52$ to 1.16$)$ & 0.71 (0.70 to 1.77$)$ & 0.78 (0.43 to 1.40$)$ \\
\hline Certolizumab vs Etanercept & 1.27 (0.77 to 2.06$)$ & 1.32 (0.46 to 1.09$)$ & 1.22 (0.66 to 2.26$)$ \\
\hline Golimumab vs Etanercept & 0.85 (0.49 to 1.44$)$ & $0.84(0.77$ to 2.28$)$ & $0.80(0.42$ to 1.53$)$ \\
\hline Abatacept vs Etanercept & 0.71 (0.44 to 1.12$)$ & 0.81 (0.49 to 1.42$)$ & $0.68(0.31$ to 1.47$)$ \\
\hline Infliximab vs Etanercept & 0.93 (0.60 to 1.42$)$ & 0.99 (0.50 to 1.31$)$ & 0.88 (0.53 to 1.47$)$ \\
\hline Rituximab vs Etanercept & $1.38(0.53$ to 3.84$)$ & 1.10 (0.66 to 1.49$)$ & $1.12(0.41$ to 3.00$)$ \\
\hline Anakinra vs Etanercept & 0.84 (0.49 to 1.43 ) & $0.84(0.72$ to 1.70$)$ & $0.82(0.41$ to 1.67$)$ \\
\hline Tocilizumab vs Etanercept & 0.62 (0.30 to 1.24$)$ & 0.89 (0.44 to 1.59$)$ & 0.91 (0.18 to 3.89$)$ \\
\hline Certolizumab vs Adalimumab & $1.63(1.01 \text { to } 2.62)^{\star}$ & $1.85(0.51$ to 1.55$)$ & 1.56 (0.80 to 3.06$)$ \\
\hline Golimumab vs Adalimumab & 1.09 (0.64 to 1.88$)$ & $1.18(1.10 \text { to } 3.14)^{\star}$ & 1.03 (0.50 to 2.06$)$ \\
\hline Abatacept vs Adalimumab & 0.92 (0.58 to 1.42 ) & 1.14 (0.70 to 1.99$)$ & 0.87 (0.38 to 1.96$)$ \\
\hline Infliximab vs Adalimumab & 1.19 (0.79 to 1.79$)$ & $1.39(0.71$ to 1.81$)$ & 1.12 (0.63 to 2.01 ) \\
\hline Rituximab vs Adalimumab & 1.77 (0.68 to 4.82$)$ & 1.54 (0.95 to 2.07$)$ & $1.43(0.51$ to 4.01$)$ \\
\hline
\end{tabular}


(Continued)

\begin{tabular}{|c|c|c|c|}
\hline Anakinra vs Adalimumab & $1.08(0.64$ to 1.82$)$ & $1.18(1.02$ to 2.33$)$ & 1.05 (0.49 to 2.27$)$ \\
\hline Tocilizumab vs Adalimumab & $0.79(0.40$ to 1.59$)$ & $1.24(0.63$ to 2.22$)$ & $1.15(0.23$ to 5.11$)$ \\
\hline
\end{tabular}

\begin{tabular}{llll}
\hline Golimumab vs Certolizumab & $0.67(0.37$ to 1.23$)$ & 0.64 (0.72 to 2.15$)$ & 0.66 (0.32 to 1.35$)$ \\
\hline Abatacept vs Certolizumab & $0.56(0.33$ to 0.94$)$ & $0.61(0.34$ to 1.18$)$ & $0.56(0.24$ to 1.27$)$ \\
\hline Infliximab vs Certolizumab & $0.73(0.45$ to 1.21$)$ & $0.75(0.34$ to 1.08$)$ & $0.72(0.39$ to 1.33$)$ \\
\hline Rituximab vs Certolizumab & $1.09(0.41$ to 3.07$)$ & $0.83(0.45$ to 1.24$)$ & 0.92 (0.32 to 2.57$)$ \\
\hline Anakinra vs Certolizumab & $0.66(0.37$ to 1.21$)$ & $0.64(0.49$ to 1.41$)$ & $0.67(0.31$ to 1.47$)$ \\
\hline Tocilizumab vs Certolizumab & $0.49(0.23$ to 1.03$)$ & $0.67(0.31$ to 1.29$)$ & $0.74(0.14$ to 3.32$)$ \\
\hline
\end{tabular}

\begin{tabular}{llll}
\hline Abatacept vs Golimumab & $0.84(0.47$ to 1.48$)$ & $0.97(0.35$ to 1.27$)$ & 0.85 (0.36 to 2.00$)$ \\
\hline Infliximab vs Golimumab & $1.09(0.62$ to 1.90$)$ & $1.18(0.55$ to 1.70$)$ & 1.10 (0.58 to 2.10$)$ \\
\hline Rituximab vs Golimumab & $1.63(0.59$ to 4.75$)$ & $1.31(0.72$ to 1.97$)$ & $1.40(0.48$ to 4.03$)$ \\
\hline Anakinra vs Golimumab & $0.99(0.52$ to 1.90$)$ & $1.00(0.78$ to 2.23$)$ & $1.03(0.46$ to 2.31$)$ \\
\hline Tocilizumab vs Golimumab & $0.73(0.34$ to 1.59$)$ & $1.06(0.49$ to 2.03$)$ & $1.14(0.22$ to 5.12$)$ \\
\hline
\end{tabular}

\begin{tabular}{llll}
\hline Infliximab vs Abatacept & $1.30(0.84$ to 2.08$)$ & 1.22 (0.56 to 1.98$)$ & $1.29(0.61$ to 2.79$)$ \\
\hline Rituximab vs Abatacept & $1.94(0.73$ to 5.43$)$ & $1.36(0.80$ to 1.90$)$ & 1.64 (0.52 to 5.11$)$ \\
\hline Anakinra vs Abatacept & $1.17(0.67$ to 2.14$)$ & $1.04(0.85$ to 2.16$)$ & 1.20 (0.49 to 3.01$)$ \\
\hline Tocilizumab vs Abatacept & $0.86(0.42$ to 1.81$)$ & $1.09(0.53$ to 2.02$)$ & $1.33(0.25$ to 6.41$)$ \\
\hline
\end{tabular}

\begin{tabular}{llll}
\hline Rituximab vs Infliximab & $1.49(0.57$ to 4.13$)$ & 1.11 (0.61 to 1.98$)$ & 1.27 (0.47 to 3.40$)$ \\
\hline Anakinra vs Infliximab & $0.91(0.53$ to 1.57$)$ & $0.85(0.75$ to 1.63$)$ & $0.94(0.46$ to 1.88$)$ \\
\hline Tocilizumab vs Infliximab & $0.67(0.33$ to 1.34$)$ & $0.90(0.46$ to 1.56$)$ & 1.03 (0.21 to 4.45$)$ \\
\hline & & & $0.74(0.25$ to 2.22$)$ \\
\hline Anakinra vs Rituximab & $0.60(0.21$ to 1.68$)$ & $0.76(0.52$ to 1.51$)$ & $0.81(0.13$ to 4.45$)$ \\
\hline
\end{tabular}


(Continued)
Tocilizumab vs Anakinra
0.74 (0.34 to 1.60$)$
1.06 (0.47 to 1.39$)$
$1.10(0.21$ to 5.15$)$

\section{Footnotes}

*=statistically significant; OR = odds ratio; $95 \% \mathrm{Cl}=95 \%$ credible interval

Appendix 10. Pairwise treatment comparison: total adverse events - network meta-analysis MTC

\begin{tabular}{llll}
\hline Comparison & $\begin{array}{l}\text { Standard Dose Model } \\
\text { OR }(95 \% \mathrm{Cl})\end{array}$ & $\begin{array}{l}\text { Unadjusted Dose Model } \\
\text { OR }(95 \% \mathrm{Cl})\end{array}$ & $\begin{array}{l}\text { Dose Adjusted Model } \\
\text { OR }(95 \% \mathrm{Cl})\end{array}$ \\
\hline Adalimumab vs Etanercept & $0.74(0.36$ to 1.45$)$ & $1.04(0.51$ to 2.02$)$ & $0.72(0.34$ to 1.51$)$ \\
\hline Certolizumab vs Etanercept & $0.85(0.39$ to 1.77$)$ & $1.02(0.44$ to 2.32$)$ & $0.98(0.48$ to 1.99$)$ \\
\hline Golimumab vs Etanercept & $0.90(0.43$ to 1.83$)$ & $1.03(0.42$ to 2.51$)$ & $0.96(0.47$ to 1.92$)$ \\
\hline Abatacept vs Etanercept & $0.90(0.40$ to 1.94$)$ & $0.90(0.38$ to 2.10$)$ & $1.03(0.49$ to 2.16$)$ \\
\hline Infliximab vs Etanercept & $1.12(0.54$ to 2.22$)$ & $1.81(0.89$ to 3.68$)$ & $1.21(0.61$ to 2.32$)$ \\
\hline Rituximab vs Etanercept & $1.11(0.31$ to 3.80$)$ & $2.11(0.30$ to 22.4$)$ & 1.15 (0.53 to 2.48$)$ \\
\hline Anakinra vs Etanercept & $1.04(0.45$ to 2.36$)$ & $1.26(0.45$ to 3.34$)$ & 0.92 (0.37 to 2.25$)$ \\
\hline Tocilizumab vs Etanercept & $0.95(0.34$ to 2.54$)$ & $1.41(0.43$ to 4.53$)$ & \\
\hline
\end{tabular}

\begin{tabular}{|c|c|c|c|}
\hline Certolizumab vs Adalimumab & 1.14 (0.60 to 2.24$)$ & 0.98 (0.43 to 2.33$)$ & 1.37 (0.68 to 2.76$)$ \\
\hline Golimumab vs Adalimumab & $1.20(0.65$ to 2.30$)$ & 1.00 (0.40 to 2.49$)$ & 1.34 (0.68 to 2.65 ) \\
\hline Abatacept vs Adalimumab & 1.22 (0.61 to 2.45$)$ & 0.87 (0.37 to 2.09$)$ & $1.44(0.70$ to 3.00$)$ \\
\hline Infliximab vs Adalimumab & 1.51 (0.84 to 2.76$)$ & 1.74 (0.86 to 3.70$)$ & 1.68 (0.88 to 3.20$)$ \\
\hline Rituximab vs Adalimumab & $1.50(0.45$ to 4.93$)$ & 2.04 (0.30 to 22.18 ) & 1.49 (0.50 to 4.45$)$ \\
\hline Anakinra vs Adalimumab & $1.40(0.69$ to 3.00$)$ & 1.21 (0.44 to 3.32$)$ & $1.60(0.75$ to 3.45$)$ \\
\hline Tocilizumab vs Adalimumab & 1.27 (0.51 to 3.29$)$ & $1.36(0.42$ to 4.43$)$ & $1.29(0.52$ to 3.15$)$ \\
\hline
\end{tabular}

\begin{tabular}{lccc}
\hline Golimumab vs Certolizumab & $1.06(0.53$ to 2.10$)$ & 1.01 (0.35 to 2.78) & 0.98 (0.51 to 1.87$)$ \\
\hline Abatacept vs Certolizumab & $1.07(0.50$ to 2.22$)$ & $0.88(0.33$ to 2.31$)$ & 1.06 (0.53 to 2.11$)$ \\
\hline Infliximab vs Certolizumab & $1.32(0.68$ to 2.53$)$ & $1.77(0.75$ to 4.22$)$ & 1.23 (0.67 to 2.25) \\
\hline Rituximab vs Certolizumab & $1.31(0.38$ to 4.40$)$ & $2.07(0.28$ to 23.37$)$ & $1.09(0.37$ to 3.20$)$ \\
\hline
\end{tabular}


(Continued)

\begin{tabular}{llll} 
Anakinra vs Certolizumab & $1.22(0.57$ to 2.73$)$ & $1.23(0.40$ to 3.65$)$ & 1.17 (0.57 to 2.43$)$ \\
\hline Tocilizumab vs Certolizumab & $1.11(0.42$ to 2.94$)$ & $1.39(0.39$ to 4.85$)$ & $0.94(0.39$ to 2.22$)$ \\
\hline
\end{tabular}

\begin{tabular}{llll}
\hline Abatacept vs Golimumab & 1.01 (0.49 to 2.07$)$ & $0.87(0.31$ to 2.48$)$ & 1.08 (0.55 to 2.13) \\
\hline Infliximab vs Golimumab & $1.26(0.66$ to 2.33$)$ & $1.75(0.70$ to 4.54$)$ & 1.26 (0.70 to 2.26) \\
\hline Rituximab vs Golimumab & $1.25(0.36$ to 4.07$)$ & $2.05(0.27$ to 24.09$)$ & 1.11 (0.38 to 3.23) \\
\hline Anakinra vs Golimumab & $1.16(0.55$ to 2.52$)$ & $1.22(0.38$ to 3.90) & $1.19(0.59$ to 2.47$)$ \\
\hline Tocilizumab vs Golimumab & $1.06(0.41$ to 2.74$)$ & $1.36(0.37$ to 5.12$)$ & $0.96(0.41$ to 2.26$)$ \\
\hline
\end{tabular}

\begin{tabular}{lccc}
\hline Infliximab vs Abatacept & $1.24(0.65$ to 2.39$)$ & $2.01(0.87$ to 4.77$)$ & 1.17 (0.63 to 2.14$)$ \\
\hline Rituximab vs Abatacept & $1.23(0.35$ to 4.23$)$ & $2.35(0.32$ to 26.50$)$ & $1.03(0.34$ to 3.11$)$ \\
\hline Anakinra vs Abatacept & $1.15(0.52$ to 2.66$)$ & $1.40(0.45$ to 4.33$)$ & 1.11 (0.52 to 2.38$)$ \\
\hline Tocilizumab vs Abatacept & $1.05(0.39$ to 2.8$)$ & $1.57(0.44$ to 5.65$)$ & $0.90(0.37$ to 2.17$)$ \\
\hline
\end{tabular}

\begin{tabular}{llll}
\hline Rituximab vs Infliximab & $0.99(0.30$ to 3.24$)$ & $1.16(0.17$ to 12.87$)$ & $0.88(0.31$ to 2.51$)$ \\
\hline Anakinra vs Infliximab & $0.93(0.45$ to 1.98$)$ & $0.70(0.24$ to 1.91$)$ & $0.95(0.49$ to 1.89$)$ \\
\hline Tocilizumab vs Infliximab & $0.84(0.33$ to 2.16$)$ & $0.78(0.24$ to 2.54$)$ & $0.77(0.34$ to 1.73$)$ \\
\hline
\end{tabular}

\begin{tabular}{llll}
\hline Anakinra vs Rituximab & $0.93(0.27$ to 3.44$)$ & $0.59(0.05$ to 4.61$)$ & 1.08 (0.35 to 3.29) \\
\hline Tocilizumab vs Rituximab & $0.85(0.21$ to 3.50$)$ & $0.67(0.05$ to 5.67$)$ & 0.87 (0.25 to 2.89$)$ \\
\hline & & & $0.81(0.32$ to 1.99$)$ \\
\hline Tocilizumab vs Anakinra & $0.91(0.32$ to 2.52$)$ & $1.12(0.29$ to 4.50$)$ & \\
\hline
\end{tabular}

\section{Footnotes}

* = statistically significant; $\mathrm{OR}=$ odds ratio; $95 \% \mathrm{Cl}=95 \%$ credible interval

\section{Appendix 11. Pairwise treatment comparison: withdrawals due to adverse events - network meta-analysis MTC}

\begin{tabular}{llll}
\hline Comparison & Standard Dose Model & Unadjusted Dose Model & Dose Adjusted Model \\
& OR $(95 \% \mathrm{Cl})$ & OR $(95 \% \mathrm{Cl})$ & $\mathrm{OR}(95 \% \mathrm{Cl})$ \\
\hline
\end{tabular}


(Continued)

\begin{tabular}{|c|c|c|c|}
\hline Adalimumab vs Etanercept & $1.04(0.51$ to 2.02$)$ & $0.86(0.48$ to 1.49$)$ & $1.02(0.53$ to 1.91$)$ \\
\hline Certolizumab vs Etanercept & $1.02(0.44$ to 2.32$)$ & $0.98(0.49$ to 1.96$)$ & $0.96(0.44$ to 2.08$)$ \\
\hline Golimumab vs Etanercept & $1.03(0.41$ to 2.514$)$ & $1.07(0.51$ to 2.19$)$ & $0.94(0.40$ to 2.20$)$ \\
\hline Abatacept vs Etanercept & $0.90(0.38$ to 2.10$)$ & $0.90(0.45$ to 1.75$)$ & $0.76(0.33$ to 1.75$)$ \\
\hline Infliximab vs Etanercept & $1.81(0.89$ to 3.68$)$ & $1.72(1.02 \text { to } 2.91)^{\star}$ & $1.69(0.89$ to 3.20$)$ \\
\hline Rituximab vs Etanercept & $2.11(0.30$ to 22.43$)$ & $1.87(0.90$ to 3.94$)$ & $1.31(0.27$ to 6.47$)$ \\
\hline Anakinra vs Etanercept & $1.26(0.45$ to 3.34$)$ & $1.21(0.52$ to 2.82$)$ & $1.19(0.47$ to 3.01$)$ \\
\hline Tocilizumab vs Etanercept & $1.41(0.43$ to 4.53$)$ & $1.09(0.52$ to 2.28$)$ & $1.15(0.41$ to 3.13$)$ \\
\hline
\end{tabular}

\begin{tabular}{llll}
\hline Certolizumab vs Adalimumab & $0.98(0.43$ to 2.33$)$ & 1.14 (0.57 to 2.33$)$ & 0.95 (0.44 to 2.12$)$ \\
\hline Golimumab vs Adalimumab & $1.00(0.40$ to 2.49$)$ & 1.24 (0.59 to 2.58$)$ & 0.93 (0.39 to 2.22$)$ \\
\hline Abatacept vs Adalimumab & $0.87(0.37$ to 2.09$)$ & $1.05(0.52$ to 2.08$)$ & 0.75 (0.32 to 1.76$)$ \\
\hline Infliximab vs Adalimumab & $1.74(0.86$ to 3.70$)$ & $2.00(1.17 \text { to } 3.49)^{\star}$ & $1.66(0.87$ to 3.23$)$ \\
\hline Rituximab vs Adalimumab & $2.04(0.30$ to 22.18$)$ & $2.17(1.04 \text { to } 4.74)^{\star}$ & $1.29(0.26$ to 6.55$)$ \\
\hline Anakinra vs Adalimumab & $1.21(0.44$ to 3.32$)$ & $1.41(0.61$ to 3.32$)$ & $1.17(0.46$ to 3.03$)$ \\
\hline Tocilizumab vs Adalimumab & $1.36(0.42$ to 4.43$)$ & $1.27(0.60$ to 2.69$)$ & $1.14(0.41$ to 3.15$)$ \\
\hline
\end{tabular}

\begin{tabular}{llll}
\hline Golimumab vs Certolizumab & $1.01(0.35$ to 2.78$)$ & 1.09 (0.46 to 2.51) & 0.97 (0.37 to 2.57) \\
\hline Abatacept vs Certolizumab & $0.88(0.33$ to 2.31$)$ & $0.91(0.40$ to 2.03$)$ & $0.79(0.30$ to 2.05$)$ \\
\hline Infliximab vs Certolizumab & $1.77(0.75$ to 4.22$)$ & $1.75(0.89$ to 3.47$)$ & $1.75(0.79$ to 3.84$)$ \\
\hline Rituximab vs Certolizumab & $2.07(0.28$ to 23.37$)$ & $1.89(0.82$ to 4.55$)$ & $1.36(0.26$ to 7.27$)$ \\
\hline Anakinra vs Certolizumab & $1.23(0.40$ to 3.65$)$ & $1.24(0.48$ to 3.16$)$ & $1.24(0.44$ to 3.46$)$ \\
\hline Tocilizumab vs Certolizumab & $1.39(0.39$ to 4.85$)$ & $1.11(0.47$ to 2.60$)$ & $1.20(0.39$ to 3.59$)$ \\
\hline
\end{tabular}

\begin{tabular}{llll}
\hline Abatacept vs Golimumab & $0.87(0.31$ to 2.48$)$ & $0.84(0.37$ to 1.94$)$ & 0.81 (0.30 to 2.24$)$ \\
\hline Infliximab vs Golimumab & $1.75(0.70$ to 4.53$)$ & $1.62(0.79$ to 3.34$)$ & 1.80 (0.76 to 4.28) \\
\hline Rituximab vs Golimumab & $2.05(0.27$ to 24.09$)$ & $1.76(0.73$ to 4.30$)$ & $1.38(0.26$ to 7.74$)$ \\
\hline Anakinra vs Golimumab & $1.22(0.38$ to 3.90$)$ & $1.14(0.44$ to 3.02$)$ & $1.27(0.43$ to 3.81$)$ \\
\hline
\end{tabular}


(Continued)
Tocilizumab vs Golimumab
$1.36(0.37$ to 5.12$)$
1.03 (0.43 to 2.49 )
1.23 (0.38 to 3.95$)$

\begin{tabular}{llll}
\hline Infliximab vs Abatacept & $2.01(0.87$ to 4.77$)$ & $1.92(1.01 \text { to } 3.71)^{\star}$ & 2.21 (0.98 to 5.09) \\
\hline Rituximab vs Abatacept & $2.35(0.32$ to 26.5$)$ & $2.07(0.91$ to 4.92$)$ & 1.72 (0.32 to 9.40$)$ \\
\hline Anakinra vs Abatacept & $1.40(0.45$ to 4.32$)$ & $1.35(0.53$ to 3.47$)$ & 1.57 (0.53 to 4.68) \\
\hline Tocilizumab vs Abatacept & $1.57(0.44$ to 5.65$)$ & 1.22 (0.53 to 2.84) & 1.51 (0.47 to 4.78) \\
\hline
\end{tabular}

\begin{tabular}{llll}
\hline Rituximab vs Infliximab & $1.16(0.17$ to 12.87$)$ & $1.09(0.53$ to 2.26$)$ & 0.78 (0.16 to 3.85) \\
\hline Anakinra vs Infliximab & $0.70(0.24$ to 1.91$)$ & $0.71(0.31$ to 1.60$)$ & 0.71 (0.28 to 1.80$)$ \\
\hline Tocilizumab vs Infliximab & $0.78(0.24$ to 2.54$)$ & $0.64(0.31$ to 1.30$)$ & $0.68(0.24$ to 1.88$)$ \\
\hline
\end{tabular}

\begin{tabular}{llll}
\hline Anakinra vs Rituximab & $0.59(0.05$ to 4.61$)$ & $0.65(0.24$ to 1.68$)$ & 0.91 (0.16 to 5.16$)$ \\
\hline Tocilizumab vs Rituximab & $0.67(0.05$ to 5.67$)$ & $0.59(0.24$ to 1.40$)$ & $0.88(0.15$ to 5.20$)$ \\
\hline & & & $0.97(0.28$ to 3.22$)$ \\
\hline Tocilizumab vs Anakinra & $1.12(0.29$ to 4.49$)$ & $0.90(0.34$ to 2.41$)$ & \\
\hline
\end{tabular}

\section{Footnotes}

* = statistically significant; OR = odds ratio; $95 \% \mathrm{Cl}=95 \%$ credible interval

Appendix 12. Pairwise treatment comparison: serious infections - network meta-analysis MTC

\begin{tabular}{llll}
\hline Comparison & $\begin{array}{l}\text { Standard Dose Model } \\
\text { OR }(95 \% \mathrm{Cl})\end{array}$ & $\begin{array}{l}\text { Unadjusted Dose Model } \\
\text { OR }(95 \% \mathrm{Cl})\end{array}$ & $\begin{array}{l}\text { Dose Adjusted Model } \\
\text { OR }(95 \% \mathrm{Cl})\end{array}$ \\
\hline Adalimumab vs Etanercept & $0.95(0.38$ to 2.29$)$ & $1.06(0.51$ to 2.23$)$ & $1.03(0.45$ to 2.35$)$ \\
\hline Certolizumab vs Etanercept & $3.68(1.01 \text { to } 16.3)^{\star}$ & $3.91(1.19 \text { to } 15.01)^{\star}$ & $3.63(1.07 \text { to } 14.16)^{\star}$ \\
\hline Golimumab vs Etanercept & $0.86(0.28$ to 2.39$)$ & $1.09(0.46$ to 2.57$)$ & $0.89(0.32$ to 2.36$)$ \\
\hline Abatacept vs Etanercept & $0.76(0.25$ to 2.12$)$ & $0.99(0.43$ to 2.28$)$ & $0.84(0.31$ to 2.28$)$ \\
\hline Infliximab vs Etanercept & $1.09(0.45$ to 2.56$)$ & $1.32(0.69$ to 2.53$)$ & $0.92(0.40$ to 2.00$)$ \\
\hline Rituximab vs Etanercept & $0.20(0.02$ to 1.74$)$ & $0.98(0.50$ to 1.94$)$ & $0.36(0.11$ to 1.02$)$ \\
\hline Anakinra vs Etanercept & $3.15(0.80$ to 14.5$)$ & $3.33(0.95$ to 14.30$)$ & $3.16(0.87$ to 13.69$)$ \\
\hline
\end{tabular}


(Continued)

$\begin{array}{llll}\text { Tocilizumab vs Etanercept } \quad 0.65(0.13 \text { to } 3.07) & 1.28(0.51 \text { to } 3.20) & 0.61(0.15 \text { to } 2.30)\end{array}$

\begin{tabular}{|c|c|c|c|}
\hline Certolizumab vs Adalimumab & $3.90(1.03 \text { to } 17.17)^{\star}$ & $3.67(1.12 \text { to } 14.45)^{\star}$ & $3.57(1.03 \text { to } 14.11)^{\star}$ \\
\hline Golimumab vs Adalimumab & $0.90(0.29$ to 2.63$)$ & $1.03(0.42$ to 2.49$)$ & $0.87(0.30$ to 2.33$)$ \\
\hline Abatacept vs Adalimumab & $0.80(0.26$ to 2.33$)$ & $0.94(0.40$ to 2.16$)$ & $0.82(0.30$ to 2.30$)$ \\
\hline Infliximab vs Adalimumab & $1.15(0.46$ to 2.81$)$ & $1.25(0.64$ to 2.44$)$ & $0.89(0.39$ to 2.02$)$ \\
\hline Rituximab vs Adalimumab & $0.21(0.02$ to 1.89$)$ & $0.92(0.46$ to 1.86$)$ & $0.35(0.10$ to 1.02$)$ \\
\hline Anakinra vs Adalimumab & $3.33(0.83$ to 15.4$)$ & $3.14(0.88$ to 13.50$)$ & $3.08(0.82$ to 13.88$)$ \\
\hline Tocilizumab vs Adalimumab & $0.69(0.14$ to 3.32$)$ & $1.21(0.47$ to 3.06$)$ & $0.59(0.14$ to 2.25$)$ \\
\hline
\end{tabular}

\begin{tabular}{llll}
\hline Golimumab vs Certolizumab & $0.23(0.04 \text { to } 0.97)^{\star}$ & $0.28(0.07$ to 1.01$)$ & $0.24(0.05 \text { to } 0.94)^{\star}$ \\
\hline Abatacept vs Certolizumab & $0.20(0.04 \text { to } 0.86)^{\star}$ & $0.25(0.06 \text { to } 0.89)^{\star}$ & $0.23(0.05 \text { to } 0.91)^{\star}$ \\
\hline Infliximab vs Certolizumab & $0.29(0.07$ to 1.08$)$ & $0.34(0.09$ to 1.06$)$ & $0.25(0.06 \text { to } 0.85)^{\star}$ \\
\hline Rituximab vs Certolizumab & $0.05(0.004 \text { to } 0.59)^{\star}$ & $0.25(0.07 \text { to } 0.80)^{\star}$ & $0.10(0.02 \text { to } 0.40)^{\star}$ \\
\hline Anakinra vs Certolizumab & $0.86(0.14$ to 5.18$)$ & $0.85(0.16$ to 4.68$)$ & $0.87(0.16$ to 4.79$)$ \\
\hline Tocilizumab vs Certolizumab & $0.17(0.02$ to 1.08$)$ & $0.33(0.08$ to 1.22$)$ & $0.17(0.03$ to 0.85$)$ \\
\hline
\end{tabular}

\begin{tabular}{llll}
\hline Abatacept vs Golimumab & $0.88(0.26$ to 3.07$)$ & 0.91 (0.35 to 2.38) & 0.95 (0.30 to 3.07) \\
\hline Infliximab vs Golimumab & $1.27(0.45$ to 3.81$)$ & $1.22(0.54$ to 2.73$)$ & 1.03 (0.39 to 2.86) \\
\hline Rituximab vs Golimumab & $0.24(0.02$ to 2.26$)$ & 0.90 (0.39 to 2.08) & 0.40 (0.11 to 1.38$)$ \\
\hline Anakinra vs Golimumab & $3.68(0.84$ to 19.96$)$ & $3.06(0.79$ to 14.64$)$ & 3.62 (0.88 to 17.70$)$ \\
\hline Tocilizumab vs Golimumab & $0.75(0.15$ to 4.32$)$ & $1.17(0.42$ to 3.37) & 0.69 (0.15 to 2.99) \\
\hline
\end{tabular}

\begin{tabular}{llll}
\hline Infliximab vs Abatacept & $1.44(0.53$ to 4.07$)$ & 1.33 (0.64 to 2.86) & 1.09 (0.40 to 2.94) \\
\hline Rituximab vs Abatacept & $0.27(0.02$ to 2.68$)$ & $0.98(0.45$ to 2.22$)$ & 0.42 (0.11 to 1.44$)$ \\
\hline Anakinra vs Abatacept & $4.20(0.96$ to 22.06$)$ & $3.35(0.902$ to 15.30$)$ & $3.79(0.90$ to 19.04$)$ \\
\hline Tocilizumab vs Abatacept & $0.86(0.16$ to 4.76$)$ & $1.28(0.48$ to 3.56) & $0.72(0.16$ to 3.08) \\
\hline
\end{tabular}


(Continued)

\begin{tabular}{llll} 
Rituximab vs Infliximab & $0.19(0.02$ to 1.65$)$ & $0.74(0.41$ to 1.34$)$ & 0.39 (0.12 to 1.15$)$ \\
\hline Anakinra vs Infliximab & $2.90(0.75$ to 13.41$)$ & $2.50(0.74$ to 10.50$)$ & 3.47 (0.94 to 15.64$)$ \\
\hline Tocilizumab vs Infliximab & $0.60(0.12$ to 2.88$)$ & $0.97(0.41$ to 2.28$)$ & $0.67(0.16$ to 2.54$)$ \\
\hline
\end{tabular}

\begin{tabular}{llll}
\hline Anakinra vs Rituximab & $15.73(1.42 \text { to } 238.30)^{\star}$ & $3.40(0.99$ to 14.21$)$ & $9.04(2.05 \text { to } 49.06)^{\star}$ \\
\hline Tocilizumab vs Rituximab & $3.20(0.25$ to 49.00$)$ & $1.31(0.53$ to 3.17$)$ & 1.71 (0.35 to 8.37$)$ \\
\hline
\end{tabular}

\begin{tabular}{llll}
\hline Tocilizumab vs Anakinra & $0.20(0.03$ to 1.35$)$ & $0.38(0.08$ to 1.53$)$ & $0.19(0.03$ to 1.05$)$
\end{tabular}

\section{Footnotes}

${ }^{\star}=$ statistically significant; $\mathrm{OR}=$ odds ratio; $95 \% \mathrm{Cl}=95 \%$ credible interval

\section{FEE D B A C K}

\section{Feedback from Lode Dewulf, 13 December 2011}

\section{Summary}

Our feedback cannot be submitted through this website without losing the formatting of the tables and texts.

Our feedback has, however, already been submitted by email to Dr Singh (author) on Dec 1, 2011, and to Jordi Pardo Pardo (acting managing editor) on Dec 13, 2011.

It is for this feedback that $\mathrm{I}$, on behalf of the author group, accept the below rules and terms of use.

With limited head-to-head data available, systematic reviews and meta-analyses have been used by clinicians and other decision makers to assess potential differences in safety and efficacy between agents in order to guide treatment choices.

Cochrane reviews are acknowledged as one of the definitive sources of systematic reviews and provide a useful resource for practicing physicians and reimbursement bodies. The recent Cochrane meta-analysis by Singh et al. 2011 is one of the most ambitious reviews of biologics to date and is the first systematic assessment of the safety of the nine biologics licensed for the treatment of rheumatoid arthritis (RA). Using a network meta-analysis approach, the authors endeavored to address the important question of whether or not there are differences in safety outcomes between the agents. Based on the authors' hypothesis that "most adverse events from medications are independent of the underlying diagnoses for which the medication is being used", safety data were pooled across a very broad patient population including studies conducted in both rheumatological and non-rheumatological diseases. While the work conducted by Singh et al. represents an important first attempt to compare the safety of the biologic agents using a systematic approach and raises some important questions for further research, it is important to understand some of the potential limitations of the approach and methods used in such a broad review.

In view of the importance given to meta-analyses for guiding treatment decisions, in this letter attention is drawn to the fact that the conclusions made in the Singh et al. 2011 article are not in line with clinical trial data and findings from other meta-analyses and therefore should be interpreted with caution. The authors' conclusions relating to serious infectious events (SIEs) are discussed to illustrate a number of important concerns relating to the methodology and assumptions made in the article. The objective is to help readers better understand the methods employed and their potential limitations in order to avoid the risk of misinterpretation. It is hoped that this letter will stimulate discussion and provide insights and learning for future meta-analyses to ensure that appropriate assumptions and adjustments for confounding factors are made and that readers are able to more critically interpret findings.

Submitter conflict of interest statement:

I am currently employed as Chief Medical Affairs Officer by UCB, marketing authorization holder of certolizumab Pegol. I have no other disclosures to make. 


\section{Reply}

We thank Dr. Dewulf for his letter and concerns raised. This network meta analysis (NMA), similar to the traditional meta-analysis (MA), made certain assumptions, and tested those assumptions to the extent possible - heterogeneity, assessed with tau-squared; and pooling of AEs across all diagnoses, tested with subgroup analyses by diagnosis. Given that some assumptions are needed to be made in order to perform a NMA, why should anyone ever care to perform NMA of biologics in RA? In the last decade nine biologics to treat RA have been launched. However, with the exception of Schiff et al., there have been no published studies that directly compare one biologic to another. In the meantime, clinicians and patients struggle to choose between these medications. Therefore, indirect comparisons using NMA methodology are needed to compare these biologics.

Dr. Dewulf also states that our NMA results do not agree with "clinical trial data and findings of other meta-analyses", without referencing any of these data and analyses, whether it be published or unpublished. Without providing the specific data and analyses, we are unable to respond directly to this comment. However, we found consistency between our review and the published systematic reviews by Alonso-Ruiz 2008, who reported higher withdrawal rates due to adverse events in infliximab compared to control treatment (AlonsoRuiz A et al. Tumor necrosis factor alpha drugs in rheumatoid arthritis: systematic review and metaanalysis of efficacy and safety. BMC Musculoskeletal Disorders 2008;9(52):1-27.) and Wiens 2010, that reported no difference in serious infections or serious adverse events between adalimumab, etanercept and infliximab, compared to control (Wiens A, Venson R, Correr CJ, Otuki MF, Pontarolo R. Meta-analysis of the efficacy and safety of adalimumab, etanercept, and infliximab for the treatment of rheumatoid arthritis. Pharmacotherapy 2010 April;30(4):339-53).

The example of serious infections was cited, with a caution to interpret the findings considering the limitations. We found that certolizumab pegol was associated with statistically significantly higher odds of serious infections compared to control, and higher odds than 5 other biologics in indirect comparison (about 4 times higher for certolizumab). As an example of robustness of our findings, 5 sensitivity analyses were conducted from several perspectives and we found that the OR for certolizumab pegol versus control for serious infections ranged between 4.12 and 4.81, a statistically significant result in each instance. Similarly, for comparing biologics to each other, three sensitivity analyses were performed, namely, a standard dose model, an unadjusted dose model and a dose-adjusted model. The significant differences between certolizumab pegol and five other biologics in the standard dose model (main model), persisted in sensitivity analyses in the unadjusted and dose-adjusted models for each comparison, with one minor exception of certolizumab versus golimumab, where confidence interval crossed one $(0.28,95 \% \mathrm{Cl} 0.07$ to 1.01$)$ in an unadjusted dose model.

Finally, without any mention of what confounding factors should have been adjusted for, we are unable to respond to the issue of unadjusted confounding.

We agree that like any research study, our systematic review has certain limitations. We explicitly stated these limitations in the abstract and discussion section of our paper. However one must not overlook the strengths of our systematic review and network meta-analysis and the robustness of its findings. We hope that this NMA will generate more interest in this topic. Advances in NMA methodology will further advance this field in the future.

\section{Contributors}

Jasvinder Singh, George Wells, Robin Christensen, Elizabeth Tanjong Ghogomu, John Macdonald, Rachelle Buchbinder, Peter Tugwell on behalf of the authors.

\section{WHAT'S NEW}

\begin{tabular}{lll}
\hline Date & Event & Description \\
\hline 26 April 2016 & Amended & Links to references corrected \\
\hline
\end{tabular}

\section{H I S T O R Y}

Protocol first published: Issue 10, 2010

Review first published: Issue 2, 2011

\begin{tabular}{lll}
\hline Date & Event & Description \\
\hline 5 August 2015 & Amended & minor edits ( $P$ value for serious infections corrected; $P=0.015)$ \\
\hline
\end{tabular}




\begin{tabular}{lll}
\hline Date & Event & Description \\
\hline 28 March 2013 & Amended & Authors' affiliations updated \\
\hline 15 January 2013 & Amended & Minor edits \\
\hline 12 April 2012 & Amended & Minor edits \\
\hline 5 January 2012 & Amended & Statistical re-analyses. \\
\hline 5 January 2012 & Feedback has been incorporated & $\begin{array}{l}\text { Responses to queries from Lode Dewulf, Chief Medical Affairs Of- } \\
\text { ficer, UCB Pharma. }\end{array}$ \\
\hline 12 April 2011 & Amended & Summary of Findings table revised. \\
\hline
\end{tabular}

\section{CONTRIBUTIONS OF AUTHORS}

Concept: JS, RC, GW, PT, RB

Title registration: JS, RB

Protocol draft: JS

Protocol editing: JS, GW, RC, ETG, NS, JKM, GF, LL, GG, ML, LM, JS, PT, RB

Title and abstract review: ETG, GF, JKM, PT, DF, Michelle Foote

Data abstraction: JS, ETG, NS, JKM, GF, LL, GG, ML, LM, JSchmitt, PT, RB, DF, TW, HS, SH, JR, RJ, Michelle Foote, Bharbhoor Dhaliwal

Data analysis: GW, RC, CC

Drafting the review: JS, RB, LM, EG

Editing and revising the review: JS, GW, RC, ETG, LM, NS, JKM, GF, LL, GG, ML, DF, J Schmitt, TW, PT, RB

\section{DECLARATIONS OF INTEREST}

JS: speaker honoraria from Abbott; research grants from AMGEN, Allergan, Takeda, Savient; consultant fee from Savient, URL Pharma, Novartis and Takeda.

GW: research grant and consultant fee from Bristol-Myers Squibb; consultant fees from Abbott, Amgen, UCB; Data Safety Monitoring for Novartis.

RC: has received consulting fees, honoraria, research or institutional support, educational grants, equipment, services or expenses from: Abbott, Astellas Pharma, Axellus, Bristol-Myers Squibb, Cambridge Nutritional Foods, Centocor, DSM Nutritional Products, Hypo-Safe, MSD, MundiPharma, NorPharma, Pharmavie, Pfizer, Roche, Sanofi-Aventis, Scandinavian Clinical Nutrition.

ETG: none

NS: none

JKM: none

Filippini: none

DF: none

Lopes: none

La Mantia: none 
Guyatt: in the last 5 years, Dr Guyatt has received grant funding from Pfizer, Lotte and John Hecht Foundation, Bristol-Myers-Squibb, and Astra Zeneca. Dr Guyatt has also received consultation fee from Up-To-Date and Eli Lilly Canada. To our knowledge, none of these are conflicted with the subject matter of this submission.

Lunn: honoraria from Baxter in relation to advisory boards on the use of IVIG.

LM: none

Schmitt: research grant from Wyeth.

PT: grants/honoraria from Bristol Myers, Chiltern International, and UCB

RB: honoraria for the 3e initiative in 2010 funded by Abbott; Principal Investigator for the Australian Rheumatology Association Database (ARAD) - The Australian Rheumatology Association has received unrestricted educational grants from Abbott, Amgen, Roche and Wyeth for ARAD.

JR: none

SH: none

TW: none

HS: none

RJ: none

CC: none

\section{SOURCES OFSUPPORT}

\section{Internal sources}

- Institute of Population Health, University of Ottawa, Canada.

Logistic support

- The Parker Institute: Musculoskeletal Statistics Unit, Copenhagen University Hospital, Denmark.

The Oak Foundations provide support to the Parker Institute

\section{External sources}

- Canadian Institutes of Health Research, Knowledge Synthesis Grant, Canada.

Funding for logistics, organization and administrative support

- National Institutes of Health Research, Cochrane Review Incentive Scheme 2009, UK.

Funding for administrative support

\section{INDEX TERMS}

\section{Medical Subject Headings (MeSH)}

Antibodies, Monoclonal [*adverse effects]; Biological Products [ ${ }^{*}$ adverse effects]; Immunologic Factors [ ${ }^{*}$ adverse effects]; Patient Dropouts [statistics \& numerical data]; Randomized Controlled Trials as Topic

\section{MeSH check words}

Humans 